\title{
ANÁLISE DO DESENVOLVIMENTO VEGETATIVO E PRODUTIVIDADE DA PALMEIRA PUPUNHA (Bactris gasipaes Kunth) SOB NÍVEIS DE IRRIGAÇÃO E ADUBAÇÃ̃O NITROGENADA
}

\author{
ADRIANA RAMOS
}

Tese apresentada à Escola Superior de Agricultura "Luiz de Queiroz", Universidade de São Paulo, para obtenção do título de Doutor em Agronomia, Área de Concentração: Irrigação e Drenagem

P I R A C I C A B A

Estado de São Paulo - Brasil

$$
\text { Julho - } 2002
$$




\title{
ANÁLISE DO DESENVOLVIMENTO VEGETATIVO E PRODUTIVIDADE DA PALMEIRA PUPUNHA (Bactris gasipaes Kunth) SOB NÍVEIS DE IRRIGAÇÃO E ADUBAÇÃ̃O NITROGENADA
}

\author{
ADRIANA RAMOS \\ Engenheiro Agrônomo
}

Orientador: Prof. Dr. MARCOS VINÍCIUS FOLEGATTI Co-Orientadora: Dra. MARILENE LEÃO ALVES BOVI

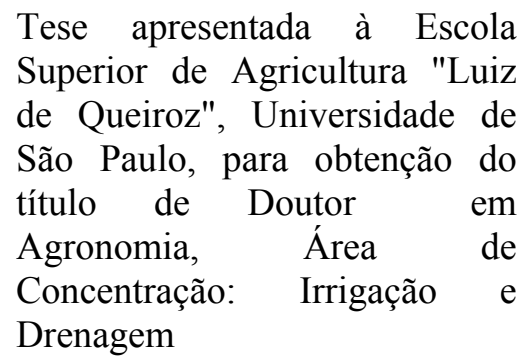

P I R A C I C A B A

Estado de São Paulo - Brasil

Julho -2002 


\section{Dados Internacionais de Catalogação na Publicação (CIP) DIVISÃO DE BIBLIOTECA E DOCUMENTAÇÃO - ESALQ/USP}

\section{Ramos, Adriana}

Análise do desenvolvimento vegetativo e produtividade da palmeira pupunha (Bac tris ga sípa es Kunth) sob níveis de imigação e adubação nitrogena da / Adriana Ramos. - - Piracic aba, 2002.

113 p. : il.

Tese (Doutorado) - Escola Superior de Agric ultura Luiz de Queiroz, 2002.

Bibliografia.

1. Desenvolvimento vegetal 2. Fertiliza ntes nitrogenados 3. Irriga ção 4. Pupunha I. Título

CDD 634.6

\section{"Permitida a cópia total ou parcial deste documento, desde que citada a fonte - $\mathrm{O}$ autor"}




\title{
DEDICO
}

\author{
A minha querida família \\ Pessoas muito especiais de quem sempre recebi muito \\ amor. \\ A Alcester Mendes \\ Companheiro de todos os momentos com quem aprendi \\ que a humildade é uma grande virtude e o amor é o sentimento \\ mais belo da vida.
}

Sem vocês esta conquista seria impossível. 
“As conquistadas são muito importantes, mas a forma como chegamos a elas é essencial para que possamos nos sentir realmente felizes." 


\section{AGRADECIMENTOS}

À Escola Superior de Agricultura "Luiz de Queiroz" - Universidade de São Paulo, pela oportunidade de realização desse curso.

A FAPESP, pela concessão da bolsa de estudo e pelo financiamento do da pesquisa.

Ao Professor Dr. Marcos Vinícius Folegatti pela orientação e pela relação de amizade e confiança.

A Dra. Marilene Leão Alves Bovi pela co-orientação no trabalho com valiosas sugestões e pela atenção e disponibilidade.

Aos professores do Curso de Pós-Graduação em Irrigação e Drenagem.

Aos amigos Maurício Coelho Filho e Luis Fernando S. M. Campeche, pela dedicação, companheirismo e amizade na condução do experimento.

Aso amigos Nádia F. Rossi, Glenda e Leonardo pelo carinho e companheirismo.

A Silvana Cardoso pela amizade, principalmente na etapa de conclusão do trabalho.

Aos estagiários do GPID (grupo de práticas em irrigação e drenagem).

Aos colegas de Curso de Pós-Graduação pela amizade e cooperação durante o curso.

Aos funcionários pelos serviços prestados e amizade.

Aos funcionários da Biblioteca pelas sugestões e correções.

Enfim, a todos aqueles que de alguma forma colaboraram para a realização deste trabalho. 


\section{AGRADECIMENTO ESPECIAL}

Aos amigos de todos os momentos Magali S. Tanaka e Francisco J. de Oliveira

Parise pelas correções e sugestões feitas ao trabalho e, principalmente, pela amizade leal e verdadeira.

A Adriano Valentim Diotto pela contribuição em todas as etapas do trabalho. 


\section{SUMÁRIO}

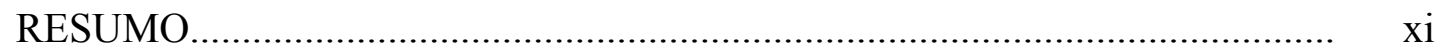

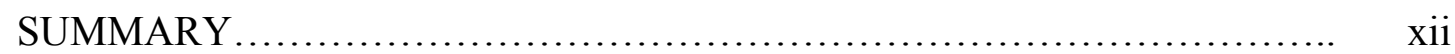

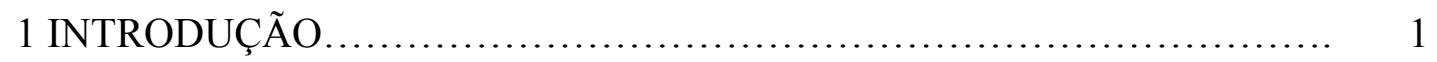

2 REVISÃO DE LITERATURA............................................................ 4

2.1 Considerações gerais sobre a pupunheira.................................................. 4

2.2 Sistema radicular........................................................................... 5

2.2.1 Métodos para análise do sistema radicular.............................................. 5

2.2.2 Distribuição espacial do sistema radicular............................................. 6

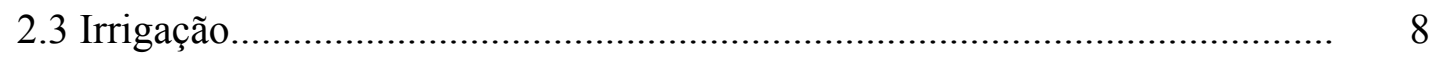

2.4 Necessidade nutricional: nitrogênio....................................................... 10

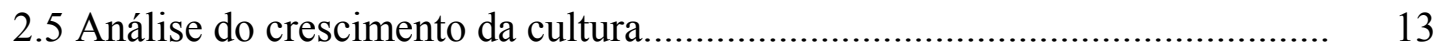

3 MATERIAL E MÉTODOS..................................................................... 15

3.1 Caracterização da área experimental..................................................... 15

3.2 Implantação da cultura......................................................................... 17

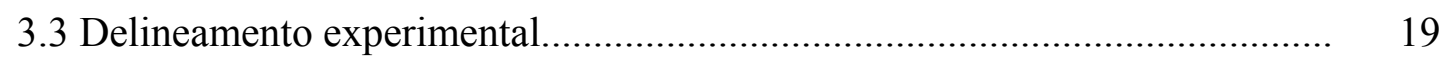

3.4 Manejo da irrigação............................................................................ 21

3.5 Fertirrigação..................................................................................... 22

3.6 Tratos culturais...................................................................................... 24

3.7 Avaliação do desenvolvimento vegetativo................................................. 25

3.7.1 Área foliar.................................................................................. 26

3.8 Avaliação do sistema radicular................................................................. 26

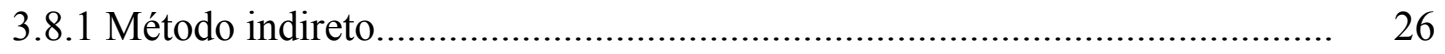

3.8.2 Método direto....................................................................................... $\quad 30$ 


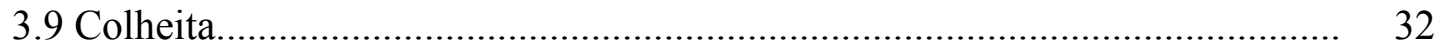

3.10 Análise estatística................................................................................. 34

4 RESULTADOS E DISCUSSÃO............................................................. 35

4.1 Variáveis meteorológicas........................................................................ 35

4.2 Manejo de água.................................................................................. 37

4.3 Distribuição espacial do sistema radicular em função da lâmina de irrigação $\quad 40$

4.4 Análise do desenvolvimento vegetativo de plantas......................................... 47

4.4.1 Altura...................................................................................... 48

4.4.2 Diâmetro da planta.............................................................................. 53

4.4.3 Número de folhas............................................................................... 58

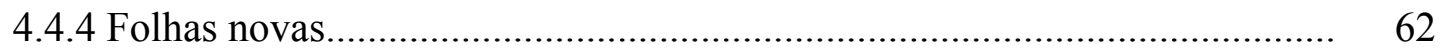

4.4.5 Comprimento da folha....................................................................... 66

4.4.6 Número de perfilhos................................................................................ 70

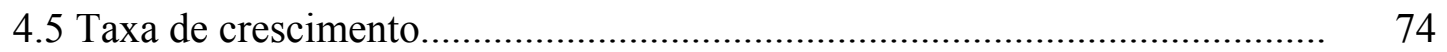

4.5.1 Taxa de crescimento em altura...............................................................

4.5.2 Taxa de crescimento em diâmetro............................................................ 79

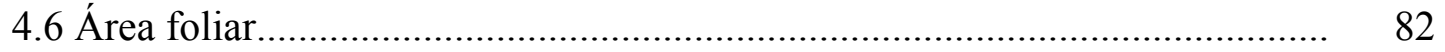

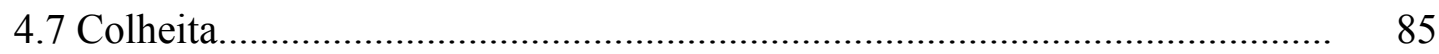

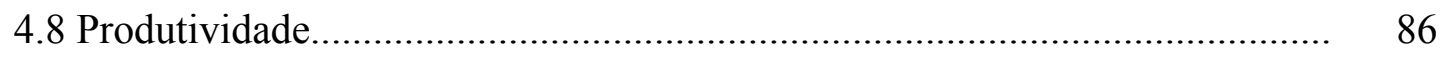

4.9 Estado nutricional das plantas................................................................. 92

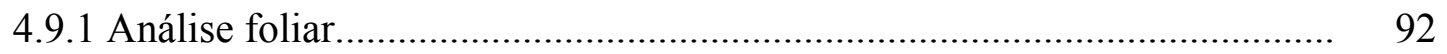

4.10 Métodos para determinação da distribuição radicular.................................... 95

4.10.1 Método indireto................................................................................ 95

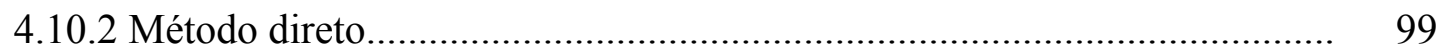

4.10.3 Comparação entre os métodos direto e indireto........................................... 101

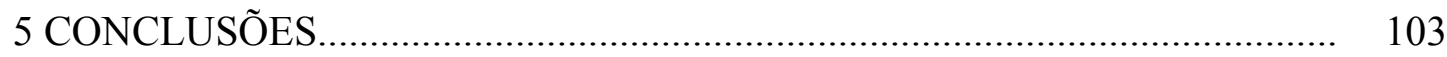

REFERÊNCIAS BIBLIOGRÁFICAS.............................................................. 106 


\title{
ANÁLISE DO DESENVOLVIMENTO VEGETATIVO E PRODUTIVIDADE DA PALMEIRA PUPUNHA (Bactris gasipaes Kunth) SOB NÍVEIS DE IRRIGAÇÃO E ADUBAÇÃO NITROGENADA
}

\author{
Autor: ADRIANA RAMOS \\ Orientador: Prof. Dr. MARCOS VINÍCIUS FOLEGATTI \\ Co-Orientadora: Pesq. Dra. MARILENE LEÃO ALVES BOVI
}

\section{RESUMO}

O presente trabalho tem como objetivo avaliar o efeito da aplicação de lâminas de irrigação com níveis de adubação nitrogenada no desenvolvimento vegetativo, produtividade de palmito e na distribuição espacial do sistema radicular da pupunheira. O experimento foi conduzido dos 12 aos 34 meses após o plantio (abril/2000 a fevereiro/2002), período este que corresponde à fase de maior crescimento da cultura, no campo experimental de Irrigação e Drenagem, da Fazenda Areão da Escola Superior de Agricultura "Luiz de Queiroz" - ESALQ/USP, localizada no município de Piracicaba S.P. à latitude de $22^{\circ} 42^{\prime} 30^{\prime} \mathrm{S}$ e longitude de $47^{\circ} 30^{\prime} 00^{\prime \prime} \mathrm{W}$. O delineamento empregado foi em blocos casualizados, com os tratamentos distribuídos em esquema fatorial $3 \times 4$. Os tratamentos referentes às lâminas de irrigação foram $\mathrm{L}_{1}, \mathrm{~L}_{2}, \mathrm{~L}_{3}$ e $\mathrm{L}_{4}$ equivalentes a 0 , $50 \%, 100 \%$ e $120 \%$ da evapotranspiraçõo de referência determinada em função do 
Tanque Classe A. Os níveis de nitrogênio aplicados foram $\mathrm{N}_{1}, \mathrm{~N}_{2}$ e $\mathrm{N}_{3}$ correspondentes a $0,200 \mathrm{~kg} \mathrm{ha}^{-1} \mathrm{ano}^{-1}$ e $400 \mathrm{~kg} \mathrm{ha}^{-1} \mathrm{ano}^{-1}$ de N, aplicado sob a forma de nitrato de potássio, nitrato de cálcio e uréia. Foram realizadas fertirrigações semanais, pelo emprego de uma bomba injetora de diafragma. Já, as avaliações do desenvolvimento vegetativo foram feitas pelas medidas de algumas variáveis de crescimento e produtividade. A distribuição espacial do sistema radicular foi determinada pelos métodos: direto, com abertura de trincheiras e digitalização de imagens e indireto, em que a área potencial de absorção das raízes foi estimada em função da variação de umidade entre dias subseqüentes. Houve efeito significativo dos tratamentos (irrigação e adubação) para todos os parâmetros de crescimento e de produção de palmito, em grande parte dos períodos avaliados. Os tratamentos com déficit hídrico (L2) e sem irrigação (L1) apresentaram os menores crescimentos nos parâmetros avaliados acarretando uma redução de $18 \%$ a $27 \%$ na produção total de palmito. Apesar de não ter ocorrido diferenças estatísticas entre os tratamentos L3 e L4, os maiores crescimentos e produtividades foram obtidas em L3 (100\% ETo). Para nitrogênio, N2 e N3 também não diferiram estatisticamente entre si, entretanto, maiores respostas foram obtidas em N2 $\left(200 \mathrm{~kg} \mathrm{ha}^{-1}\right.$ ano $\left.^{-1}\right)$. Portanto, levando-se em conta o crescimento da planta e os custos de aplicação de lâminas e fertilizantes, os resultados indicam que a irrigação com 100\% ETo e adubação com $200 \mathrm{~kg}$ de $\mathrm{N} \mathrm{ha}^{-1} \mathrm{ano}^{-1}$ são as recomendadas para a pupunheira cultivada em condições agroclimatológicas semelhantes à região do presente estudo. As regressões para as lâminas de irrigação apresentaram efeitos lineares significativos para todas as variáveis analisadas, com exceção do número de perfilhos, vindo confirmar o alto consumo de água da cultura e a importância da irrigação quando cultivada em áreas com déficit hídrico. Para o nitrogênio, com exceção dos parâmetros relacionados à produção de palmito, todos os demais apresentaram efeitos lineares das regressões, ressaltando a importância do nitrogênio no desenvolvimento vegetativo da pupunheira. Todos os tratamentos (lâminas) aplicados resultaram em uma distribuição radicular (área e comprimento) bastante superficial, variando de 97,8\%, 92\%,86,7\% e 97,8\% de raízes distribuídas até a profundidade de 0,40 m. 


\title{
VEGETATIVE DEVELOPMENT AND PRODUCTION OF PALM PEACH (Bactris gasipaes Kunth) UNDER LEVELS OF IRRIGATION AND N FERTILIZER
}

\author{
Author: ADRIANA RAMOS \\ Adviser: Prof. Dr. MARCOS VINÍCIUS FOLEGATTI \\ Co-Adviser: Pesq. Dra. MARILENE LEÃO ALVES BOVI
}

SUMMARY

Peach palm (Bactris gasipaes Kunth) plants were subjected to different irrigation and $\mathrm{N}$ fertilizer treatments in an experiment field conducted at the Irrigation and Drainage Area (22 $42^{\prime} 30^{\prime} \mathrm{S}$ and $\left.47^{\circ} 30^{\prime} 00^{\prime \prime} \mathrm{W}\right)$ of Areão Agricultural Experiment Area, ESALQ/USP, Piracicaba, SP, Brazil. The principal aim was to study the growth, development and yield of peach palm in the first plant yield cycle (April 2000 to February 2002), and also the spatial distribution of the root system. The irrigation $(0 \%$, $50 \%, 100 \%$ and $120 \%$ of ETo) and $\mathrm{N}$ fertilizer $\left(0 \mathrm{~kg} \cdot \mathrm{ha}^{-1} \cdot \mathrm{year}^{-1}, 200 \mathrm{~kg} \cdot \mathrm{ha}^{-1} \cdot \mathrm{year}^{-1}\right.$ and

$400 \mathrm{~kg} \cdot \mathrm{ha}^{-1} \cdot$ year $^{-1}$ ) treatments were grouped in randomized blocks resulting in a $3 \times 4$ factorial experiment. The water and $\mathrm{N}$ were applied through the use of a diaphragmactivated injection pump in a weekly basis. Plant parameters (as LAI obtained by the use of LAI 2000) were measured monthly to accompany the plant growth and development and the spatial distribution of the root system was evaluated by the use of a direct method (measuring by image analysis of the length and area of roots exposed by digging a soil-trench within the crop) and an indirect one (recording the moisture level 
differences between subsequent days). Significative differences among treatments were found in almost the total duration of the experiment. The water deficit treatments $(0 \%$ and $50 \%$ of ETo) showed the lowest values of all parameters resulting in yield losses of $18 \%$ to $27 \%$. On the other hand, the $100 \%$ of ETo treatment exhibited the highest ones, although the $120 \%$ of ETo treatment did not differ statistically from the former. Also, the $200 \mathrm{kgN} \cdot \mathrm{ha}^{-1}$.year ${ }^{-1}$ and $400 \mathrm{kgN} \cdot \mathrm{ha}^{-1}$.year ${ }^{-1}$ treatments did not differ statistically, showing the $200 \mathrm{kgN} \cdot \mathrm{ha}^{-1}$.year ${ }^{-1}$ treatment the highest values. All parameters except offshoot number increased linearly with increasing water and except yield with increasing $\mathrm{N}$. The root system in all treatments concentrated in the shallow layers of the soil with $97,8 \%, 92 \%, 86,7 \%$ and $97,8 \%$ of roots distributed until $40 \mathrm{~cm}$ depth. 


\section{INTRODUÇÃO}

Denomina-se palmito o produto comestível, de formato cilíndrico, macio e tenro, extraído da extremidade superior do estipe de certas palmeiras. É constituído, basicamente, pelo meristema apical e um número variável de folhas internas, ainda não plenamente desenvolvidas e imbricadas, sendo envolto e protegido pela bainha das folhas adultas mais externas (Bovi, 1998).

O palmito é considerado uma iguaria fina, de grande aceitação no mercado brasileiro, o que torna o Brasil o maior produtor, consumidor e exportador de palmito em conserva. Não obstante, o palmito é também muito apreciado em outros países como França, Japão, Itália, Estados Unidos, entre outros.

Apesar de ser o maior produtor de palmito, o Brasil ainda explora o produto de forma extrativa, baseada quase que totalmente no aproveitamento e degradação das reservas naturais. Conseqüentemente, surgiu a necessidade de uma exploração racional de palmito em substituição a exploração predatória.

Há uma grande diversidade de palmeiras potencialmente importantes para a produção de palmito. Dentre elas, citam-se algumas como a palmeira juçara (Euterpe edulis Mart.), açaí (Euterpe oleracea Mart.), indaiá (Attalea dubia), guariroba (Syagrus oleracea), por exemplo. Entretanto, cada uma apresenta características indesejáveis para palmito, além do fato de apresentarem corte tardio e baixo rendimento.

No Brasil, várias palmeiras produzem palmito comestível, porém, duas espécies do gênero Euterpe são predominantes: E. edulis Mart. e E. oleracea Mart., conhecidas popularmente como palmeira juçara e açaizeiro. Estas espécies levam de 7 a 12 anos 
para o corte. Ademais, são obtidas freqüentemente via extrativismo predatório, acarretando a diminuição de nossas reservas presentes na Mata Atlântica, já muito depauperadas.

A pupunheira (Bactris gasipaes Kunth) surge como uma opção para atender a demanda interna e externa, por apresentar características desejáveis quanto ao seu cultivo e qualidade do palmito produzido. Quando cultivada em condições adequadas, apresenta um rápido crescimento, produzindo palmitos de boa qualidade $\mathrm{e}$ perfilhamento, o que confere caráter permanente de exploração à cultura.

A palmeira pupunha ou pupunheira (Bactris gasipaes, Kunth) tem sido objeto de pesquisas intensivas e desenvolvimento em várias partes da América tropical (Clement, 1995), graças, principalmente, às suas características de precocidade, rusticidade e perfilhamento.

Como os primeiros estudos realizados com a palmeira pupunha para produção de palmito no Brasil datam de 1978 (Germek, 1981), ainda são poucas as informações quanto às necessidades hídricas e nutricionais dessa cultura, particularmente, quando cultivada no Estado de São Paulo.

Segundo Bovi (1997), o interesse do Brasil no cultivo da palmeira pupunha para produção de palmito teve expansão considerável e caráter mais empresarial a partir de 1988. Os estados brasileiros que receberam maior quantidade de sementes de pupunha foram Espírito Santo, São Paulo, Rondônia, Pará, Bahia e Rio Grande do Norte.

Bovi, em 1997, estimou que o Brasil possuía cerca de 28milhões de pés de pupunha ou uma área aproximada de 5.600 hectares cultivados com material inerme de origem peruana. No entanto, a autora sugeriu que a estimativa era maior que o total realmente implantado, pois ocorreram alguns insucessos no cultivo da pupunheira devido à falta de conhecimento sobre a cultura, como sua exigência em características físicas do solo - especialemnte, no que se refere à compactação e drenagem necessidade de adubação pesada para máxima produtividade e sua exigência hídrica. Irrigação faz-se necessária quando é cultivada em áreas com déficit hídrico. Embora a área cultivada com pupunheira do tipo inerme, atualmente, seja bem maior (acima de 20 
mil ha), os insucessos continuam sendo freqüentes devido aos mesmos fatores acima apontados (Bovi, comunicação pessoal).

Sendo assim, justifica-se plenamente este trabalho que tem como objetivo avaliar o efeito de aplicação de lâminas de irrigação por gotejamento com níveis de adubação nitrogenada no desenvolvimento da parte aérea e na distribuição espacial do sistema radicular da palmeira pupunha. 


\section{REVISÃO DE LITERATURA}

\subsection{Considerações gerais sobre a pupunheira}

A distribuição geográfica desta espécie compreende territórios entre latitudes $16^{\circ}$ $\mathrm{N}$ e $17^{\circ} \mathrm{S}$ (Mora-Urpi ,1984) desde o norte de Honduras até o sul da Bolívia e do leste de São Luís do Maranhão à oeste do Rio das Esmeraldas no Equador (Barbosa, 1993).

As condições climáticas ideais para que a pupunheira apresente um maior desenvolvimento vegetativo e produtividade são precipitação em torno de $2000 \mathrm{~mm} / \mathrm{ano}$, temperatura média anual de $22^{\circ} \mathrm{C}$ e umidade relativa superior a $80 \%$. Sua ocupação dáse, principalmente, em áreas com altitudes inferiores a 900 m (Bovi ,1998).

A pupunheira perfilha, produzindo numerosos brotos basais que crescem rapidamente. Outra vantagem é o fato da pupunheira não apresentar escurecimento enzimático, uma vez que não apresenta em sua composição química as enzimas polifenoloxidase e peroxidase, um dos principais problemas no processamento do palmito de outras espécies de palmeira (Ferreira, 1982).

Segundo Bovi (1998), a produção do palmito nessa espécie é viável a partir dos 18 meses de idade, efetuando-se adubação apropriada e irrigação para suprir as necessidades hídricas da cultura, em regiões de baixa pluviosidade.

A pupunha, nativa da região Amazônica, apresenta grande quantidade de espinhos (com formas, tamanhos, números e local variados) nas diversas partes da planta: estipe, folíolos, pecíolo/ráquis etc. Esses dificultam bastante o seu manuseio, tanto no viveiro quanto no campo e, particularmente, no corte do palmito. O tipo inerme, 
material sem espinho, importado da região de Yurimaguas, Peru, é o que tem sido mais empregado nas pesquisas e explorações comerciais. Entretanto, no caso da pupunha, é grande a desuniformidade de resposta dos materiais atualmente comercializados, o que indica tanto a necessidade de melhoramento genético para todas as espécies produtoras de palmito (Agrianual, 1998), como a necessidade de estudos que permitam um maior conhecimento sobre as características fisiológicas da planta em determinadas condições de manejo e cultivo.

\subsection{Sistema radicular}

\subsubsection{Métodos para análise do sistema radicular}

Há muito tempo sabe-se que o estudo do desenvolvimento das raízes, sua distribuição, extensão e atividade são de extrema importância para o entendimento científico da produção agrícola. O mesmo vale para as alterações provocadas no solo e na planta por razões naturais e pelo manejo químico e físico do solo (Pearson, 1974).

Existem diferentes métodos para analisar a distribuição do sistema radicular no perfil do solo. Bohm (1979) relacionou alguns como as escavações, monólitos, perfurações com trado, trincheiras, parede de vidro, elemento marcado e plantas em vasos. No entanto, métodos tradicionais de estudo da distribuição das raízes são muito trabalhosos e demorados, envolvendo contagem manual do número de raízes presentes em um perfil de solo ou em amostras retiradas com trados ou anéis.

$\mathrm{O}$ desenvolvimento de metodologias que facilitem e tornem mais rápido o processo de obtenção de dados acerca do sistema radicular é importante no sentido de impulsionar os trabalhos de pesquisa sobre a interação solo-raiz. Com o avanço da informática, surgiram novas metodologias para análise do sistema radicular, dentre as quais destaca-se o método da utilização de câmera de vídeo e análise de imagens (Crestana et al., 1994). 
Segundo Bohm (1979), existem também os métodos de avaliação indireta, entre os quais encontra-se o decréscimo da água no solo com o tempo, que se baseia na hipótese de que a taxa de variação de umidade está correlacionada com a quantidade de raízes. Estes métodos apresentam a vantagem de serem não destrutivos, porém algumas considerações devem ser feitas. Durante os períodos das medições não deve existir fluxo significativo de água de uma camada para outra. Assume-se que a única perda seja por transpiração. Neste caso, em períodos que ocorrerem precipitações freqüentes, o trabalho pode ser prejudicado, visto que, a permanência do solo em potencial mátrico elevado, sem que ocorram variações de umidade no solo, não representa bem a extração de água pelas raízes. Sendo assim, para minimizar os efeitos da chuva e evaporação da água no solo, deve-se manter o solo coberto durante o período de realização do experimento.

Whitney et al. (1990) empregaram como método direto para determinação do consumo de água, densidade de raízes e produtividade de citrus, a utilização de uma sonda de neutrons para determinação do conteúdo de umidade do solo. Os autores afirmam que maiores umidades foram obtidas na linha de plantas do que na entrelinha e que isso pode ser um indicativo de diferenças na densidade de raízes.

Ao passo que Santos (1997) estudou a distribuição do sistema radicular da cultura da mangueira recorrendo a dois métodos: a) direto, com a abertura de trincheiras e digitalização das imagens e b) indireto, pela avaliação da área potencial de absorção das raízes por meio da variação de umidade do solo, estimada com base na variação do potencial mátrico.

\subsubsection{Distribuição espacial do sistema radicular}

O sistema radicular da pupunheira é do tipo fasciculado, com presença de raízes primárias, secundárias, terciárias e quaternárias (Bovi et al., 1999). As duas últimas são consideradas os órgãos principais de absorção em palmeiras e podem ser bastante desenvolvidas em solos ricos em nutrientes e matéria orgânica (Tomlinson, 1990). 
Estudos sobre o sistema radicular da pupunheira realizados por Ferreira et al. (1980; 1995) e Morales \& Vargas (1990), o aponta como superficial e expandido, uma vez que a maior concentração das raízes da planta estudada (75\% a $80 \%)$ se encontrava na profundidade de $0,2 \mathrm{~m}$ a partir do centro da planta.

Já, Bassoi et al. (1998) analisaram a distribuição da massa radicular da pupunheira, irrigada por sulcos, para determinar a profundidade efetiva do sistema radicular quando cultivada em Latossolo vermelho-amarelo de Petrolina - PE. A maior concentração de raízes ocorreu até a profundidade de $0,2 \mathrm{~m}$, sendo que a presença de lençol freático a $0,8 \mathrm{~m}$ de profundidade contribuiu para essa distribuição bastante superficial $(0 \mathrm{~m}-0,2 \mathrm{~m})$.

Por sua vez, Bovi et al. (1999) em estudo sobre densidade radicular de progênies de pupunheira em função de adubação NPK, retirando amostras com trado quando as plantas tinham cerca de dois anos no campo, observaram que a maior densidade radicular esteve sempre relacionada a doses elevadas de nitrogênio (400 kg/ha/ano de $\mathrm{N})$.

A seguir serão feitas algumas citações sobre estudos realizados com coqueiro (Cocos nucifera L.) e dendezeiro (Elaeis guineensis), palmeiras com sistema radicular e crescimento inicial semelhante à pupunheira, pois, são escassos os dados sobre o comportamento da pupunheira. Cabe recordar que são escassos os dados sobre o comportamento da pupunheira em relação ao seu desenvolvimento vegetativo e radicular em diferentes regiões do Brasil.

O sistema radicular de duas variedades de coqueiro (Cocos nucifera L.) de diferentes idades, crescendo em um solo aluvial, em floresta tropical seca foram estudados por Avilan et al. (1984). Nessa situação, observou-se que a distribuição radicular foi marcadamente influenciada, tanto pelas características físicas do solo, bem como pelas práticas agronômicas (aplicação de fertilizantes e irrigação). Independente da idade da planta, a maior parte das raízes foram encontradas na camada de $0,0 \mathrm{~m}-0,3$ $\mathrm{m}$ de profundidade e num raio $1,5 \mathrm{~m}$ na projeção da copa.

Com o objetivo de identificar os materiais mais adaptados à exploração no Nordeste do Brasil, região esta caracterizada por má distribuição das chuvas e presença 
de déficit hídrico prolongado, Cintra et al. (1993) avaliaram a distribuição do sistema radicular de seis cultivares de coqueiro (Cocos nucifera L.). No que diz respeito à distribuição do sistema radicular no perfil do solo, encontrou-se que, independente da cultivar, em torno de $70 \%$ das raízes situavam-se a $0,40 \mathrm{~m}$ de profundidade e num raio de $1 \mathrm{~m}$ em torno do tronco. E que após o período chuvoso, $80 \%$ se concentrava na camada de $0,1 \mathrm{~m}$ a $0,5 \mathrm{~m}$. Após o período seco, este percentual caiu para $60 \%$, com $20 \%$ a mais de raízes abaixo de $0,5 \mathrm{~m}$.

Pomier \& Bonneau (1987), também trabalhando com coqueiros, detectaram a natureza dinâmica da distribuição do sistema radicular controlada, na maioria das vezes, pelo tipo de solo, condições de umidade, práticas culturais e pelas diferenças varietais.

\subsection{Irrigação}

A água destaca-se entre os fatores que afetam o desenvolvimento vegetativo por ser o meio de difusão dos solutos nas células e solvente para a maioria das reações bioquímicas. Ainda, funciona como regulador de temperatura e é básica na sustentação dos tecidos vegetais, dada a sua incompressibilidade.

Nas plantas em desenvolvimento, há uma continuidade no fluxo da água desde o solo até a atmosfera. A absorção, a translocação e a transpiração da água pelas plantas dependem das condições climáticas e edáficas, bem como, de certas características fisiológicas próprias à planta. Falta ou excesso de água é freqüente fator de diminuição da produção e, por isso, seu manejo é essencial para a maximização da produção agrícola.

Como a maioria das regiões produtoras de palmito (Amazonas, Pará, Rondônia, Acre) possui elevados índices pluviométricos, há poucos trabalhos de pesquisa sobre a influência da irrigação em cultivos de pupunheira. Entretanto, sabe-se que o coqueiro é uma palmácea que, assim como a pupunha, apresenta um alto consumo hídrico. Dessa forma, recorrer - se - á a alguns trabalhos com coco como fundamentação teórica. 
Nelliat (1968) estudou o efeito de diferentes freqüências de irrigação sobre o desenvolvimento vegetativo de plantas jovens de coco (Cocos nucifera L.) em uma faixa de solo arenoso, ao longo da costa oeste da Índia. Ao final do terceiro ano de avaliação, houve diferença significativa no crescimento e vigor causada pelos diferentes tratamentos. Foi encontrado um aumento em altura e diâmetro de $16,48 \mathrm{~m}$ e $3,07 \mathrm{~m}$, respectivamente, no tratamento com lâmina de $45 \mathrm{~mm}$ de água, aplicados a cada quatro dias, em relação aos demais tratamentos e com um número médio de 13,32 folhas produzidas.

Em artigo publicado por Parthasarathy (1984) sobre resultados de experimentos que estudaram a resposta do coqueiro à irrigação por gotejamento, são discutidos fatores como problemas da irrigação, os benefícios dessa tecnologia, aplicação de fertilizantes via água de irrigação e custos. Baseado nesses dados, o autor concluiu que o gasto para a implantação de um sistema de irrigação é compensado por uma maior produtividade de largas variedades de coqueiros cultivados na Índia.

Liyanage et al. (1989) pesquisaram os efeitos da irrigação no estabelecimento e crescimento de coqueiros em zonas secas do Sri-Lanka. Foram avaliados altura de planta, diâmetro do colo, produção de folhas, vigor, entre outros parâmetros. Os melhores resultados foram obtidos no tratamento que se aplicou $40 \mathrm{~mm}$ de água duas vezes por semana.

Já, Mathew et al. (1993), em estudo sobre a influência da irrigação suplementar na produtividade e uso da água em plantas adultas de coqueiro, em solo argiloso, concluíram que os melhores resultados em termos de rendimento e uso econômico da água foram alcançados a partir do segundo ano, com tratamento em que se aplicava $100 \%$ da evaporação do tanque classe A.

E Vizquez (1981) estudou o comportamento fenológico da cultura da pupunha, pela determinação da morte e longevidade das folhas, época de maior produção, crescimento em altura e diâmetro do estipe em relação à precipitação mensal e total acumulada, número de dias chuvosos e número de dias secos mensais e totais acumulados. A análise estatística dos dados revelou correlações significativas entre os parâmetros avaliados e a precipitação. Baseado nestes resultados, o autor ressalta a 
possibilidade de que a irrigação seja economicamente recomendada para o cultivo de pupunheira em regiões com baixos índices pluviométricos.

Ramos et al. (2002) avaliaram o desenvolvimento vegetativo de uma cultura de pupunheira, com três anos, em Terra Roxa Estruturada, em função de níveis de depleção de água no solo. Dentre as variáveis de crescimento avaliadas, encontraram maior desenvolvimento em diâmetro no caule, altura e maior número de folhas novas emitidas para o tratamento com maior intensidade de aplicação de água.

Ainda, Ramos et al. (2001) e Diotto et al. (2000), trabalhando com pupunheiras adultas determinaram um alto consumo hídrico pela cultura, sendo encontrados valores médios de coeficiente de cultura $(\mathrm{Kc})$ de 1,00 para a planta mãe e perfilho. Resultados semelhantes foram obtidos por Lopes et al. (2000).

Alves Júnior et al. (2000) quantificaram e qualificaram os efeitos de lâminas de irrigação sobre as características vegetativas e produtivas de pupunheiras cultivadas no Noroeste Paulista. Os autores obtiveram um maior crescimento vegetativo e produtividade no tratamento que recebeu $75 \%$ da evaporação do tanque Classe A (ECA), no corte inicial e 100\% ECA, no segundo ano de produção.

Em experimento conduzido em casa de vegetação, Oliveira et al. (2001) avaliaram a resposta da pupunheira à deficiência hídrica, em relação à taxa de assimilação de $\mathrm{CO}_{2}$, transpiração, condutância estomática e potencial de água nas folhas. Os resultados conseguidos indicaram um decréscimo no potencial de água da folha e nas trocas gasosas quando a irrigação foi interrompida por mais de seis dias. Houve recuperação total de todas as variáveis dois dias após a reirrigação, com exceção da condutância estomática.

\subsection{Necessidade nutricional: nitrogênio}

O nitrogênio é vital para o crescimento vegetativo de palmeiras, uma vez que, é largamente utilizado na síntese de proteína e faz parte da estrutura da molécula de clorofila (Salisbury \& Ross, 1991). Na ausência de adubação nitrogenada, a deficiência 
em nitrogênio é pronunciada. Com aplicações de nitrogênio, seus efeitos são significativos sobre o crescimento vegetativo de palmeiras (Rodrigues et al., 1997, Tampubolon et al., 1990 e Bonneau et al., 1993).

Zamorra (1984), em ensaios sobre nitrogênio, fósforo e potássio, em condições de campo, objetivando estabelecer a influência desses elementos na dinâmica nutricional da pupunheira, verificaram que o nitrogênio foi o elemento que mais influenciou os parâmetros avaliados, portanto, muito importante na produção de biomassa.

Gusman (1985), em experimento realizado na Costa Rica com a pupunheira, avaliou o efeito de quatro doses de nitrogênio sobre as características: peso médio do palmito bruto e líquido, rendimento bruto e número de palmito por ha/ano. Ademais, verificou que o aumento de nitrogênio influenciava positivamente os parâmetros avaliados, até a dose de $367 \mathrm{~kg}$ de $\mathrm{N} \mathrm{ha}^{-1} \mathrm{ano}^{-1}$.

Ao passo que Chepote et al. (1988) avaliaram o efeito da adubação mineral (NPK) nas fases de crescimento e produção do dendezeiro (Elaeis guineensis Jacq.), cultivado em latossolo vermelho-amarelo, na Bahia. A análise estatística mostrou efeito significativo dos tratamentos sobre a fase de crescimento e produtiva. As respostas mais expressivas foram as obtidas com a aplicação de $60 \mathrm{~kg} / \mathrm{h}, 60 \mathrm{~kg} / \mathrm{h}$ e $120 \mathrm{~kg} / \mathrm{ha}$ de N, $\mathrm{P}_{2} \mathrm{O}_{5}$ e $\mathrm{K}_{2} \mathrm{O}$, respectivamente.

Estudando a nutrição mineral de plantas jovens de coco (Cocos nucifera L.) na Indonésia, Bonneau et al. (1993) observaram que o nitrogênio é um mineral essencial para o desenvolvimento vegetativo do coqueiro, por estar relacionado com a biomassa aérea e a produção. Além do mais, apresentam resposta imediata à aplicação do mesmo. Segundo os mesmos autores, altas doses de uréia proporcionaram um aumento de $20 \%$ no perímetro do colo e $44 \%$ para emissão de folhas novas.

Secretaria \& Maravilla (1997) estudaram os efeitos da adubação mineral e orgânica sobre altura, diâmetro do colo e número de folhas de coqueiros híbridos crescendo em solo arenoso nas Filipinas. Os mesmos verificaram que a aplicação de sulfato de amônio $+\mathrm{KCL}$, durante os três primeiros anos, melhorou significativamente o crescimento vegetativo das plantas. 
Já, em experimento realizado na Bahia, Chepote et al. (1998) avaliaram o efeito da adubação NPK nas fases de crescimento e produtividade do dendezeiro (Elaeis guineensis Jacq) em latossolo vermelho-amarelo. A adubação provocou aumentos significativos do perímetro na região do colo e na produtividade.

Ainda, Rodrigues et al. (1997) estudaram na região de Manaus, de 1984 a 1990, os efeitos das adubações N, P, K e Mg sobre o crescimento e a produção do dendezeiro (Elaeis guineensis Jacq.) sobre Latossolo. Concluíram que as doses crescentes de fósforo melhoraram, de maneira significativa, a nutrição $\mathrm{N}-\mathrm{P}$, o desenvolvimento das palmeiras (até os seis anos) e sua produção (4 aos 7 anos) e que uma dose modesta de fósforo corrige rapidamente a deficiência em fósforo sem indução da deficiência pronunciada em $\mathrm{K}$.

Segundo Clement \& Bovi (2000), correlações positivas significativas foram encontradas entre algumas características vegetativas tais como, diâmetro do colo, altura, número de folhas e diâmetro do palmito em pesquisas realizadas anteriormente por Bovi et al. (1988, 1992, 1993a) e Clement et al. (1988). Todos esses autores afirmam que a análise de crescimento em pupunheira é altamente recomendada, pois por meio dela pode-se identificar e quantificar, com precisão adequada, respostas da planta aos tratamentos adotados.

Bovi et al. (2000), em estudo sobre a acumulação de biomassa radicular em pupunheira (Bactris gasipaes Kunth) e colonização por micorriza arbuscular, em função da adubação com NPK, encontraram uma variação na biomassa radicular para as diferentes quantidades de NPK aplicadas, com aumento de $112 \%$ na colonização por micorriza e de $31 \%$ na biomassa radicular, para o tratamento que recebeu $200 \mathrm{~kg} \mathrm{ha}^{-1}$ ano $^{-1}$, em relação à testemunha.

Em experimento conduzido com pupunheiras cultivadas em solo Aluvial álico em Ubatuba, SP, foram estudadas os efeitos de quatro doses de nitrogênio, fósforo e potássio, aplicados em cobertura, sobre alguns parâmetros de crescimento. Verificou-se que um máximo crescimento foi obtido com doses anuais de $400 \mathrm{~kg}$ de N, $0 \mathrm{~kg}$ de $\mathrm{P}_{2} \mathrm{O}_{5}$ e $200 \mathrm{~kg}$ de $\mathrm{K}_{2} \mathrm{O}$ por hectare. (Bovi et al., 2002). 
Ainda, segundo Bovi (1998) e Bovi et al. (1998), o número de folhas é um parâmetro que reflete bem o efeito de estresse hídrico e adubação, com respostas significativas a níveis crescentes de nitrogênio e lâminas de irrigação.

\subsection{Análise do crescimento da cultura}

Segundo Magalhães (1979), a análise de crescimento de planta consiste no método que descreve as condições morfofisiológicas da planta em diferentes intervalos de tempo, para se quantificar o desenvolvimento de um vegetal.

Para Benincasa (1988), a análise de crescimento vegetativo permite conhecer diferenças funcionais e estruturais entre plantas. Possibilita também avaliar o crescimento final da planta como um todo e a contribuição dos diferentes órgãos no crescimento total. São muitas vezes, usadas para detectar diferenças entre os tratamentos estabelecidos. A autora apresenta de forma simples como deve ser realizada uma análise de crescimento, usando exemplos práticos.

O crescimento de plantas, sob diferentes condições ambientais, pode ser mensurado de diversas maneiras: lineares, superficiais, peso e número de unidades estruturais. Entre as dimensões lineares, é possível citar a altura da planta; comprimento de ramificações, diâmetro de caules, entre outras. O crescimento também pode ser acompanhado a partir de unidades estruturais morfológicas ou anatômicas, como ramificações, folhas, flores, frutos e raízes. Estas medidas podem fornecer informações importantes quanto à fenologia e são, muitas vezes, usadas para detectar diferençiais dos efeitos de tratamento (Benincasa, 1988).

As medidas de superfície estão relacionadas, principalmente, à determinação ou estimativa da superfície fotossinteticamente ativa. Dentre elas, está o índice de área foliar, que é a relação entre a área foliar total e a área do solo sombreada pelas folhas. Métodos indiretos e diretos para a determinação do IAF das palmeiras, vêm sendo empregados por alguns autores (Clement et al., 1985; Martel \& Clement, 1986/87). 
Estudos desenvolvidos por Hartley (1977), em dendezeiro, e por Child (1974), em coqueiros, têm demonstrado que o IAF está diretamente relacionado com a produção, sendo este um importante parâmetro de avaliação da produtividade (Clement et al, 1985).

Lamade (1997) utilizou o LAI 2000 para medida direta do IAF do dendezeiro e comparou os resultados com os obtidos por metodologia indireta. Os resultados mostraram excelente correlação com o método direto. O autor concluiu que o LAI 2000 é um aparelho particularmente apropriado para medir o IAF das palmeiras.

Ao passo que Clement \& Bovi (2000) discutem métodos para análise de crescimento e produção em pupunheira, propondo a padronização de medidas a serem usadas em experimentos agronômicos e genéticos visando à produção de palmito. As medidas vegetais essenciais são: altura, importante por ser uma medida de natureza não destrutiva e facilmente obtida nos estádios iniciais de crescimento; número de folhas, relacionado com o número de folhas internas e, portanto, com a produção de palmito e número de perfilhos, associado à capacidade de regeneração da planta. Já, as medidas produtivas essenciais são: número de palmitos colhidos, peso e comprimento do palmito (tipo exportação).

Diversos trabalhos lançando mão de variáveis de crescimento vegetativo vêm sendo desenvolvidos na cultura da pupunheira (Bovi et al., 2002; Ramos et al., 2002; Oliveira et al., 2001). Diotto et al. (2001) estudaram a influência dos parâmetros climáticos sobre a taxa de crescimento em altura e diâmetro das pupunheiras e observaram que a época do ano exerceu influência na taxa de crescimento calculada em função da altura.

Correlações positivas significativas foram encontradas entre caracteres vegetativos, tais como diâmetro, altura e número de folhas, e componentes diretos da produção (massa, diâmetro e comprimento do palmito) em Bovi et al. (1988; 1992; 1993a), entre outros (Clement \& Bovi, 2000). 


\section{MATERIAL E MÉTODOS}

\subsection{CaRACTERIZAÇão dA ÁREA EXPERIMENTAL}

O estudo foi conduzido na área experimental de Irrigação e Drenagem do Departamento de Engenharia Rural, na Fazenda Areão, da Escola Superior de Agricultura "Luiz de Queiroz" - ESALQ/USP, localizada no município de Piracicaba SP, localizada a uma altitude de 576 metros e coordenadas geográficas de $22^{\circ} 42^{\prime} 30^{\prime \prime}$ de latitude sul e $47^{\circ} 30^{\prime} 00^{\prime}$ 'de longitude oeste.

O solo classifica-se como Terra Roxa Estruturada (Alfisol), série Luiz de Queiroz, apresentando declividade média de 5\%.

Segundo a classificação climática de Köppen, o clima é do tipo $\mathrm{CWa}$, isto é subtropical úmido, verão chuvoso, e inverno seco. A precipitação média anual é 1247 $\mathrm{mm}$, temperatura média $21,1^{\circ} \mathrm{C}$, umidade relativa média de $74 \%$ e velocidade do vento de 2,2 m/s com direção E/SE predominantemente (Ometto, 1991).

Para a determinação dos principais parâmetros do solo da área experimental ao lado da parcela foi escavada uma trincheira $(1 \mathrm{~m} \times 1 \mathrm{~m} \times 1 \mathrm{~m})$. dessa trincheira foram retiradas amostras de solo com estrutura deformada e indeformada, nas profundidades de 0,0-0,2 $\mathrm{m}, 0,2-0,4 \mathrm{~m}, 0,4-0,6 \mathrm{~m}$ e 0,6-0,8 m, para a determinação das características fisicohídricas. Estas amostras foram enviadas ao laboratório para determinação da análise granulométrica e densidade do solo (Tabela 1), curva de retenção da água no solo (figura 1) e análise química do solo (Tabela 2). Os resultados obtidos encontram-se nas tabelas abaixo. 


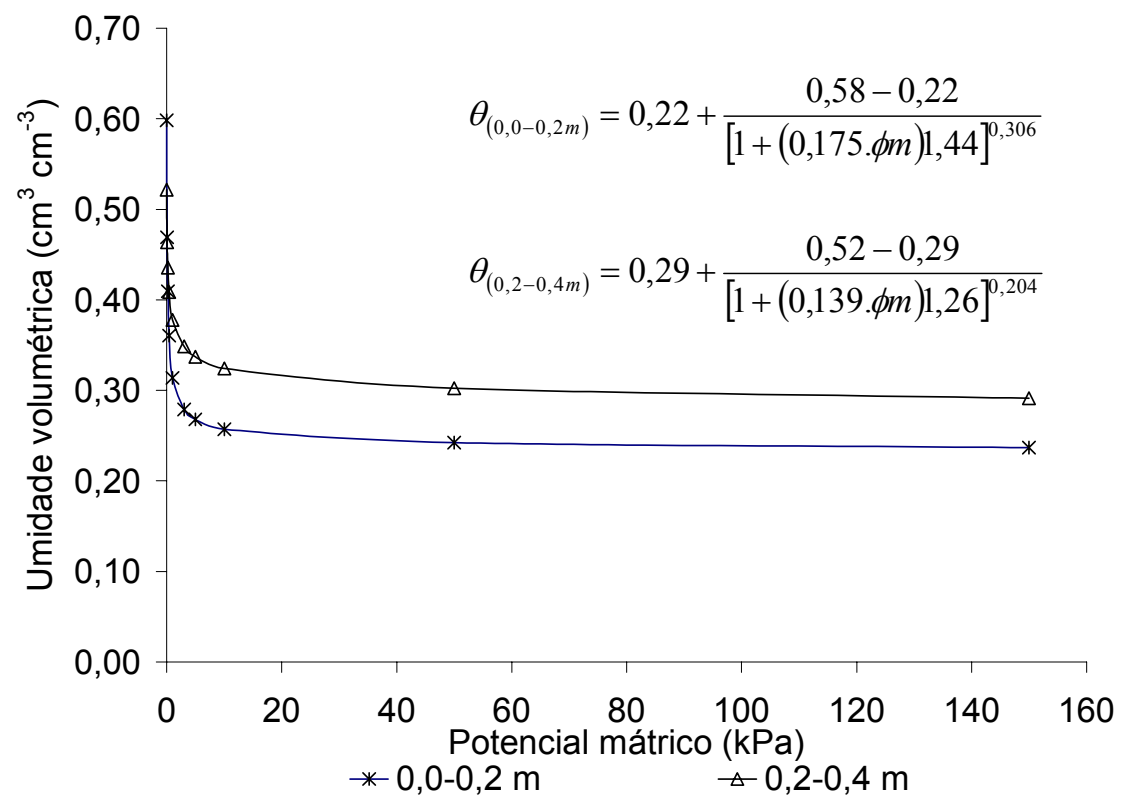

Figura 1 - Curvas de retenção da água no solo, nas camadas de 0,0-0,2 m e 0,2-0,4 m, em solo Terra Roxa Estruturada.

Tabela 1. Análise granulométrica do solo para as camadas de $0-0,2 \mathrm{~m}, 0,2-0,4 \mathrm{~m}$ e $0,4-$ $0,6 \mathrm{~m}$.

\begin{tabular}{ccccc}
\hline $\begin{array}{c}\text { Profundidade } \\
(\mathrm{m})\end{array}$ & $\begin{array}{c}\text { Argila } \\
(\%)\end{array}$ & $\begin{array}{c}\text { Silte } \\
(\%)\end{array}$ & $\begin{array}{c}\text { Areia } \\
(\%)\end{array}$ & $\begin{array}{c}\text { Densidade do solo } \\
\left(\mathrm{g} . \mathrm{cm}^{-3}\right)\end{array}$ \\
\hline $0,0-0,2$ & 40,87 & 27,64 & 31,49 & 1,60 \\
$0,2-0,4$ & 47,62 & 23,16 & 29,23 & 1,42 \\
$0,4-0,6$ & 50,30 & 23,53 & 26,17 & 1,44 \\
\hline
\end{tabular}

Tabela 2. Análise química do solo para as camadas de 0,0-0,2 m e 0,2-0,4 m.

\begin{tabular}{ccccccccccccc}
\hline $\begin{array}{c}\text { Camada } \\
(\mathrm{m})\end{array}$ & $\begin{array}{c}\mathrm{pH} \\
\mathrm{CaCl}_{2}\end{array}$ & $\begin{array}{c}\mathrm{M}, \mathrm{O}, \\
\mathrm{g} \cdot \mathrm{dm}^{-}\end{array}$ & $\mathrm{P}$ & $\mathrm{M}-\mathrm{SO} 4$ & $\mathrm{~K}$ & $\mathrm{Ca}$ & $\mathrm{Mg}$ & $\mathrm{Al}$ & $\mathrm{H}+\mathrm{Al}$ & $\mathrm{SB}$ & $\mathrm{T}$ & $\mathrm{V}$ \\
& & & & & & & $\mathrm{mmol}_{\mathrm{c}} \mathrm{dm}^{-3}$ & & & & \\
$(\%)$
\end{tabular}




\subsection{Implantação da cultura}

$\mathrm{Na}$ área experimental foi instalado um plantio de pupunheira (Figura2) em maio de 1999 no espaçamento de 2,0 $\mathrm{m}$ x 1,0 m, através de sulcos de $0,3 \mathrm{~m}$ de largura $\mathrm{x} 0,3 \mathrm{~m}$ de profundidade.

Em função do resultado obtido na análise do solo (Tabela 2), não foi realizada a aplicação de calcário. Foi aplicada apenas adubação de plantio no sulco de $20 \mathrm{Kg}$ de esterco de curral curtido mais $140 \mathrm{Kg}$ de superfosfato simples por hectare. A adubação potássica foi feita em cobertura, via fertirrigação, pela aplicação de nitrato de potássio, de acordo com a recomendação para a cultura $\left(200 \mathrm{~kg} \mathrm{ha}^{-1} \mathrm{ano}^{-1}\right)$.

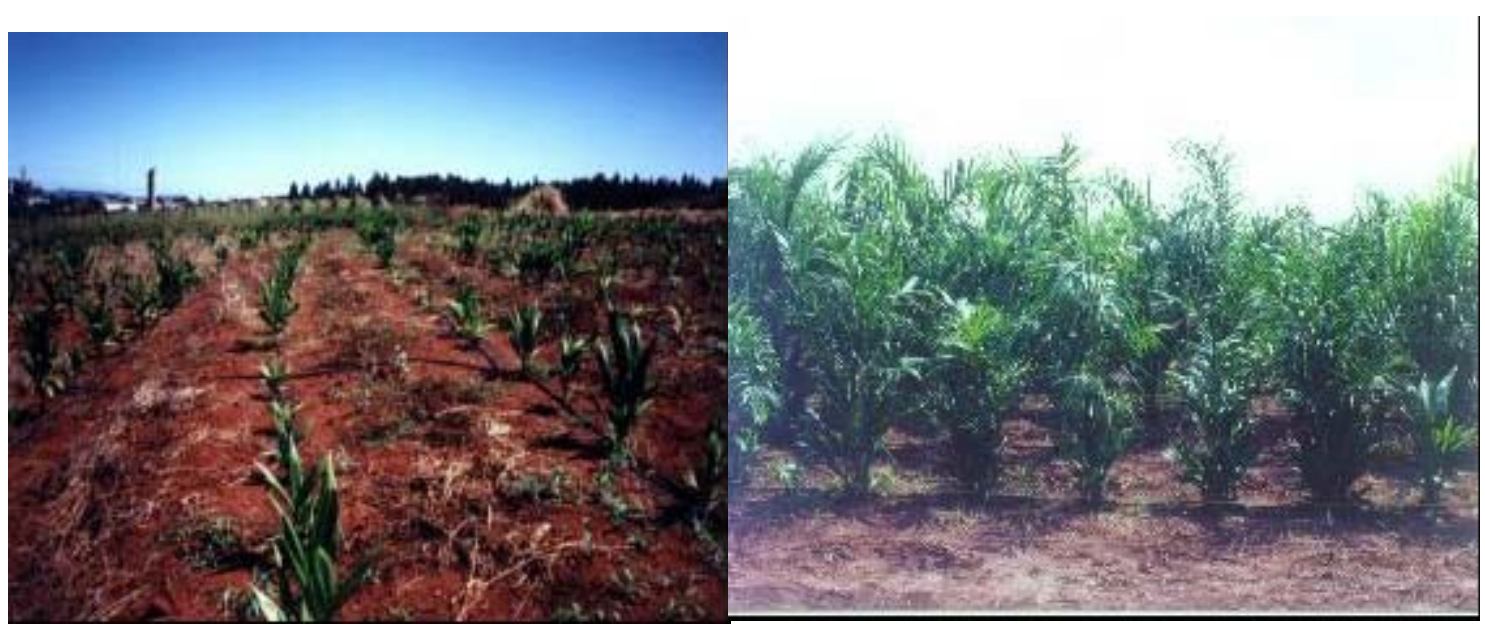

(a)

(b)

Figura 2 - Vista parcial da área experimental aos 10 (a) e aos 20 meses (b) após o plantio.

Com a chegada do inverno em maio de 1999, ocorreram mortes de um grande número de plantas, sendo necessária à realização de um replantio, realizado em novembro deste mesmo ano, época em que havia mudas prontas para o plantio. 
Para aplicação de água, foi empregado um sistema de irrigação localizada tipo gotejamento. Os gotejadores, autocompensantes de marca Katif Dripper, inseridos na linha lateral, foram espaçados entre si de 0,40 m, com vazão de 2,7 litros por hora à pressão de serviço de $30 \mathrm{kPa}$. Em cada parcela, foram instaladas válvulas reguladoras de pressão de $20 \mathrm{lb} \mathrm{pol}^{-2}$. Não foi necessária a realização do cálculo da uniformidade de distribuição, em conformidade com a metodologia recomendada por Keller e Karmeli (1975).

A água utilizada para irrigação foi bombeada de uma barragem localizada na Fazenda Areão, próxima a área experimental. Inicialmente, foi feita uma análise da água para verificar suas características químicas. A coleta de água para análise foi realizada em março de 2000 e as amostras foram coletadas no cabeçal de controle do sistema de irrigação, após o sistema de filtragem da estação de controle. Suas características estão descritas na Tabela 3.

Tabela 3. Resultados da análise química da água utilizada para irrigação.

\begin{tabular}{lcc}
\hline \multicolumn{1}{c}{ Parâmetros analisados } & Unidade & Resultado da análise de água \\
\hline Alcalinidade $\left(\mathrm{CO}_{3}{ }^{2-}+\mathrm{HCO}_{3}\right)$ & $\mathrm{mg} \mathrm{L}^{-1}$ & 21,0 \\
Cloreto $\left(\mathrm{Cl}^{-}\right)$ & $\mathrm{mg} \mathrm{L}^{-1}$ & 3,5 \\
Nitrato $\left({\left.\mathrm{N}-\mathrm{NO}_{3}\right)}\right)$ & $\mathrm{mg} \mathrm{L}^{-1}$ & 1,4 \\
Sulfato $\left(\mathrm{SO}_{4}{ }^{2-}\right)$ & $\mathrm{mg} \mathrm{L}^{-1}$ & 9,5 \\
Fósforo $(\mathrm{P})$ & $\mathrm{mg} \mathrm{L}^{-1}$ & 0,05 \\
Amônio $\left(\mathrm{N}-\mathrm{NH}_{3}\right)$ & $\mathrm{mg} \mathrm{L}^{-1}$ & 0,3 \\
Sódio $\left(\mathrm{Na}^{+}\right)$ & $\mathrm{mg} \mathrm{L}^{-1}$ & 2,3 \\
Potássio $\left(\mathrm{K}^{+}\right)$ & $\mathrm{mg} \mathrm{L}^{-1}$ & 3,0 \\
Cálcio $\left(\mathrm{Ca}^{2+}\right)$ & $\mathrm{mg} \mathrm{L}^{-1}$ & 4,6 \\
Magnésio $\left(\mathrm{Mg}^{2+}\right)$ & $\mathrm{mg} \mathrm{L}^{-1}$ & 1,9 \\
Ferro $(\mathrm{Fe})$ & $\mathrm{mg} \mathrm{L}^{-1}$ & 0,03 \\
Cobre $(\mathrm{Cu})$ & $\mathrm{mg} \mathrm{L}^{-1}$ & 0,01 \\
Manganês $(\mathrm{Mn})$ & $\mathrm{mg} \mathrm{L}^{-1}$ & 0,01 \\
Zinco $(\mathrm{Zn})$ & $\mathrm{mg} \mathrm{L}^{-1}$ & 0,07 \\
Condutividade elétrica & $\mathrm{mS} \mathrm{cm}^{-1}$ & 0,10 \\
PH & & 7,6 \\
Acidez & $\mathrm{mg} \mathrm{L}^{-1}$ & 2,5 \\
Gás Carbônico $\left(\mathrm{CO}_{2}\right)$ & $\mathrm{mg} \mathrm{L}^{-1}$ & 1,0 \\
\hline
\end{tabular}


Foi realizada uma análise foliar para verificar as quantidades de macro e micronutrientes presentes nas plantas, antes da aplicação dos tratamentos. Foram retirados dois folíolos, da folha +2 , sendo um de cada lado da ráquis foliar. Coletaram-se duas amostras, uma de plantas cujas folhas apresentavam aspecto normal e outra de plantas com encarquilhamento das folhas, com folhas pequenas deformadas, mais grossas e com nervuras suberificadas e salientes e morte do meristema apical, semelhante aos sintomas apresentados por deficiência de boro, descritos em Malavolta et al. (1997).

Tabela 4. Análise foliar de macro e micronutrientes da folha de pupunheira.

\begin{tabular}{cccccccccccc}
\hline Amostras & $\mathrm{N}$ & $\mathrm{P}$ & $\begin{array}{c}\mathrm{K} \\
\mathrm{g} \mathrm{kg}^{-1}\end{array}$ & $\mathrm{Ca}$ & $\mathrm{Mg}$ & $\mathrm{S}$ & $\mathrm{B}$ & $\mathrm{Cu}$ & $\begin{array}{c}\mathrm{Fe} \\
\mathrm{mg} \mathrm{kg}^{-1}\end{array}$ & $\mathrm{Mn}$ & $\mathrm{Zn}$ \\
\hline Amostra 1 & 27,72 & 1,78 & 16,07 & 3,15 & 1,86 & 2,0 & 14,5 & 8,7 & 271,5 & 40 & 20,2 \\
Amostra 2 & 23,38 & 2,16 & 13,77 & 3,59 & 2,30 & 2,6 & 37,3 & 6,2 & 399,6 & 35 & 21,8 \\
\hline
\end{tabular}

Pelos resultados (Tabela 4) obtidos observou-se que essas plantas (amostra 1) apresentavam teores muito inferiores de boro, em relação ás folhas da amostra 2. A partir destes resultados, começaram a ser feitas aplicações de ácido bórico, na dosagem de 2 g planta $^{-1}$.

Os dados climáticos referentes ao período de maio/2000 a fevereiro/2002 foram obtidos na estação meteorológica localizada próxima a área experimental .

\subsection{Delineamento experimental}

O delineamento experimental empregado foi em blocos casualizados, com os tratamentos divididos em um ensaio fatorial $4 \times 3$, sendo quatro lâminas de irrigação e três doses de nitrogênio, com doze tratamentos e quatro repetições, totalizando quarenta e oito parcelas (Figura 3). Cada parcela tinha as dimensões de oito metros de largura por seis metros de comprimento, totalizando uma área de $48 \mathrm{~m}^{2}$. E cada uma dela composta por quatro linhas de plantas, contendo um tratamento, composto da combinação de um 
nível de irrigação e um nível de nitrogênio, num total de trinta e duas plantas, sendo vinte e quatro plantas de bordadura e oito plantas úteis.

\begin{tabular}{|c|c|c|c|c|c|c|c|c|c|c|c|}
\hline $\bar{z}$ & $\begin{array}{l}L \\
4 \\
N \\
1\end{array}$ & $\begin{array}{l} \\
2 \\
N \\
3\end{array}$ & $\begin{array}{l}L \\
1 \\
N \\
2\end{array}$ & $\begin{array}{c}\mathrm{L} \\
1 \\
\mathrm{~N} \\
1\end{array}$ & $\begin{array}{l}L \\
4 \\
N \\
3 \\
\end{array}$ & \begin{tabular}{|l|}
$\mathrm{L}$ \\
3 \\
$\mathrm{~N}$ \\
2 \\
\end{tabular} & $\begin{array}{l} \\
3 \\
N \\
1\end{array}$ & $\begin{array}{l}\mathrm{L} \\
1 \\
\mathrm{~N} \\
2 \\
\end{array}$ & \begin{tabular}{|l|} 
\\
4 \\
$N$ \\
2 \\
\end{tabular} & $\begin{array}{l}\mathrm{L} \\
2 \\
\mathrm{~N} \\
2 \\
\end{array}$ & \begin{tabular}{|l} 
\\
$a$
\end{tabular} \\
\hline $\begin{array}{l}L \\
2 \\
N \\
1 \\
\end{array}$ & $\begin{array}{l}\mathrm{L} \\
2 \\
\mathrm{~N} \\
2 \\
\end{array}$ & $\begin{array}{l}\mathrm{L} \\
1 \\
\mathrm{~N} \\
3 \\
\end{array}$ & $\begin{array}{l}L \\
3 \\
N \\
2 \\
\end{array}$ & $\begin{array}{l}L \\
4 \\
N \\
2 \\
\end{array}$ & $\begin{array}{l}L \\
3 \\
N \\
1\end{array}$ & \begin{tabular}{|l}
$\mathrm{L}$ \\
4 \\
$\mathrm{~N}$ \\
3 \\
\end{tabular} & $\begin{array}{l}\mathrm{L} \\
1 \\
\mathrm{~N} \\
3 \\
\end{array}$ & $\begin{array}{l}\mathrm{L} \\
2 \\
\mathrm{~N} \\
1 \\
\end{array}$ & $\begin{array}{l}\mathrm{L} \\
2 \\
\mathrm{~N} \\
3 \\
\end{array}$ & $\begin{array}{c}\mathrm{L} \\
1 \\
\mathrm{~N} \\
1\end{array}$ & $\begin{array}{l} \\
3 \\
N \\
3 \\
\end{array}$ \\
\hline \begin{tabular}{|l|} 
\\
1 \\
$N$ \\
3 \\
\end{tabular} & $\begin{array}{l} \\
1 \\
N \\
2 \\
\end{array}$ & $\begin{array}{l}\mathrm{L} \\
4 \\
\mathrm{~N} \\
2 \\
\end{array}$ & $\begin{array}{l}\mathrm{L} \\
2 \\
\mathrm{~N} \\
2 \\
\end{array}$ & \begin{tabular}{|l|}
$\mathrm{L}$ \\
3 \\
$\mathrm{~N}$ \\
2 \\
\end{tabular} & $\begin{array}{l} \\
2 \\
N \\
3 \\
\end{array}$ & \begin{tabular}{|l}
$\mathrm{L}$ \\
1 \\
$\mathrm{~N}$ \\
2 \\
\end{tabular} & $\begin{array}{l}\mathrm{L} \\
3 \\
\mathrm{~N} \\
3 \\
\end{array}$ & $\begin{array}{l}L \\
2 \\
N \\
1 \\
\end{array}$ & \begin{tabular}{|l|}
$L$ \\
4 \\
$N$ \\
3 \\
\end{tabular} & $\begin{array}{c}\mathrm{L} \\
1 \\
\mathrm{~N} \\
1\end{array}$ & \begin{tabular}{|l}
$L$ \\
4 \\
$N$ \\
1 \\
\end{tabular} \\
\hline $\begin{array}{l}\mathrm{L} \\
1 \\
\mathrm{~N} \\
1 \\
\end{array}$ & $\begin{array}{l}\mathrm{L} \\
2 \\
\mathrm{~N} \\
1\end{array}$ & $\begin{array}{l}L \\
3 \\
N \\
1\end{array}$ & $\begin{array}{l}\mathrm{L} \\
3 \\
\mathrm{~N} \\
3\end{array}$ & $\begin{array}{l}\mathrm{L} \\
4 \\
\mathrm{~N} \\
3\end{array}$ & $\begin{array}{l}\mathrm{L} \\
4 \\
\mathrm{~N} \\
1\end{array}$ & \begin{tabular}{|l}
$\mathrm{L}$ \\
2 \\
$\mathrm{~N}$ \\
2
\end{tabular} & $\begin{array}{l}\mathrm{L} \\
2 \\
\mathrm{~N} \\
3 \\
\end{array}$ & $\begin{array}{l}\mathrm{L} \\
3 \\
\mathrm{~N} \\
1\end{array}$ & \begin{tabular}{|l|}
$\mathrm{L}$ \\
1 \\
$\mathrm{~N}$ \\
3 \\
\end{tabular} & \begin{tabular}{|l}
$\mathrm{L}$ \\
4 \\
$\mathrm{~N}$ \\
2
\end{tabular} & \begin{tabular}{|l|}
$\mathrm{L}$ \\
3 \\
$\mathrm{~N}$ \\
2 \\
\end{tabular} \\
\hline
\end{tabular}

a - Parcela que recebeu lâmina e adubação nitrogenada e cujas plantas serão avaliadas.

b - Cabeçal de controle.

c- Parcela que recebeu lâmina de irrigação (100\% da ETo) e cujas plantas tiveram seu sistema radicular avaliado.

Figura 3 - Diagrama esquemático da área experimental.

Os tratamentos referentes aos níveis de irrigação corresponderam às lâminas de irrigação, sendo respectivamente: $\mathrm{L}_{1}=0 \% ; \mathrm{L}_{2}=50 \% ; \mathrm{L}_{3}=100 \% ; \mathrm{L}_{4}=120 \%$ da evaporação medida por um Tanque Classe A Modificado, localizado na estação meteorológica que se encontra próxima à área experimental e cujas modificações foram desenvolvidas por Amorim Neto (1983). 
Por sua vez, os diferentes níveis de nitrogênio aplicados foram respectivamente: $\mathrm{N}_{1}=0 ; \mathrm{N}_{2}=200 \mathrm{~kg} \mathrm{ha}^{-1}$ ano $^{-1}$ e $\mathrm{N}_{3}=400 \mathrm{~kg} \mathrm{ha}^{-1}$ ano $^{-1}$ baseados na recomendação de adubação para a pupunheira apresentada por Bovi et al. (1999); Bovi \& Cantarella (1996).

Também, foram instalados tensiômetros na profundidade de $0,15 \mathrm{~m}$, nas parcelas referente ao tratamento L3N3, para determinação do momento de irrigação. A irrigação foi realizada toda vez que o tensiômetro acusava tensão de $30 \mathrm{kPa}$.

\subsection{Manejo da irrigação}

A lâmina de água aplicada foi calculada segundo a equação (1) (Doorenbos \& Pruitt, 1975), levando-se em consideração o coeficiente de cobertura (Kr).

$$
L=E C A . . K p . K r
$$

em que:

L - lâmina de irrigação (mm);

ECA - evaporação do Tanque Classe A ( $\left.\mathrm{mm} \mathrm{dia}^{-1}\right)$;

$\mathrm{Kp}$ - coeficiente do tanque, para as condições locais de cobertura vegetal, igual a 0,72 (Sentelhas et al., 1999);

$\mathrm{Kr}$ - coeficiente de cobertura do solo (0,4 até 24 meses de idade e após 0,6) (Keller e Karmeli,1975).

Após precipitações, a lâmina de irrigação foi calculada pela umidade atual utilizando a curva de retenção da água no solo, segundo a equação (2):

$$
\mathbf{C A D}=\left(\theta_{\mathrm{cc}}-\theta_{\text {atual }}\right) \cdot \mathbf{z e}
$$


em que:

CAD - capacidade de água disponível (mm);

$\theta_{\mathrm{cc}}$ - umidade do solo na capacidade de campo $\left(\mathrm{cm}^{3} . \mathrm{cm}^{-3}\right)$, obtida pela curva de retenção de água no solo na profundidade de $40 \mathrm{~cm}$, correspondente a tensão de $10 \mathrm{kPa}$;

$\theta_{\text {atual }}$ - umidade atual do solo $\left(\mathrm{cm}^{-3} \mathrm{~cm}^{-3}\right)$, obtida pela curva de retenção de água no solo na profundidade de $40 \mathrm{~cm}$, correspondente a tensão da água no solo após precipitação pluviométrica;

ze - profundidade efetiva do sistema radicular $(\mathrm{mm})$, sendo considerada à $0,4 \mathrm{~m}$.

O tempo de irrigação foi calculado pela equação (3), conforme sugerido em Keller e Karmeli (1975).

$$
T i=\frac{L \cdot A}{n g \cdot q}
$$

em que:

Ti - tempo de irrigação $(h)$;

L - lâmina de irrigação (mm);

A - área representada em cada palmeira $\left(1 \mathrm{~m}^{2}\right)$;

ng - número de gotejadores por planta:

q - vazão dos gotejadores $\left(\mathrm{L} \mathrm{h}^{-1}\right)$,

\subsection{Fertirrigação}

Durante o primeiro ano (maio/1999 a abril/2000) da cultura no campo, que corresponde a fase de estabelecimento da cultura, foram efetuadas adubações com nitrogênio $\left(0,08 \mathrm{~kg}\right.$ de $\mathrm{N}_{\text {planta }}{ }^{-1}$ ano $\left.^{-1}\right)$, baseada nos estudos realizados por Bovi et al. (2002) (400 kg ha ${ }^{-1}$ ano $\left.^{-1}\right)$, aplicadas quinzenalmente via água de irrigação. Em relação à irrigação, também foi aplicada uma lâmina uniforme para toda área (100\% ETo), utilizando-se a tensão de $30 \mathrm{kPa}$ para determinar o momento da irrigação, até que se iniciaram a aplicação dos tratamentos. 
Assim que se iniciaram os tratamentos (abril/2000), foram aplicados como fonte de nitrogênio o nitrato de potássio, nitrato de cálcio e uréia. O nitrato de cálcio foi aplicado também como fonte de cálcio para suprir os sintomas de deficiência. Bem como, o nitrato de potássio, para suprir a necessidade da cultura desse elemento (200 kg de $\mathrm{K}_{2} \mathrm{O}$ ano ${ }^{-1}$ ). Quando o nitrato de potássio foi utilizado como fonte de $\mathrm{K}_{2} \mathrm{O}$, o restante do nitrogênio necessário foi aplicado na forma de uréia.

Já, as fertirrigações foram realizadas pelo emprego de uma bomba TMB; sendo aplicada uma lâmina média de $3 \mathrm{~mm}$ em cada fertirrigação.

Como ainda não se dispunha de dados sobre a curva de absorção da cultura para nitrogênio, optou-se pela aplicação de uma dosagem uniforme, uma vez que o nitrogênio é um elemento muito importante na produção de biomassa da pupunheira. Os valores calculados estão descriminados na tabela a seguir.

Tabela 5. Quantidade de nitrogênio aplicado durante um ano, para os tratamentos de 200 $\mathrm{kg} \mathrm{ha}^{-1} \mathrm{ano}^{-1}(\mathrm{~N} 2)$ e $400 \mathrm{~kg} \mathrm{ha}^{-1} \mathrm{ano}^{-1}(\mathrm{~N} 3)$.

\begin{tabular}{ccccc}
\hline $\begin{array}{c}\text { Fases (dias após } \\
\text { plantio) }\end{array}$ & $\begin{array}{c}\text { \% de Nitrogênio } \\
\text { Aplicado }\end{array}$ & $\begin{array}{c}\text { Número de } \\
\text { Aplicações }\end{array}$ & $\begin{array}{c}\mathrm{N} 2(0,08 \mathrm{~kg} \\
\left.\text { planta }^{-1}\right)\end{array}$ & $\begin{array}{c}\text { N3 }(0,04 \mathrm{~kg} \\
\left.\text { planta }^{-1}\right)\end{array}$ \\
\hline $360-420$ & $16,6 \%$ & 8 & 3,41 & 7,68 \\
$420-480$ & $16,6 \%$ & 9 & 3,41 & 7,68 \\
$480-540$ & $16,6 \%$ & 8 & 3,41 & 7,68 \\
$540-600$ & $16,6 \%$ & 9 & 3,41 & 7,68 \\
$600-660$ & $16,6 \%$ & 8 & 3,41 & 7,68 \\
$660-720$ & $16,6 \%$ & 9 & 3,41 & 7,68 \\
Total & $100 \%$ & 51 & 20,48 & 46,08 \\
\hline
\end{tabular}

Para verificar os efeitos dos tratamentos sobre os parâmetros de crescimento em cada período avaliado foram calculadas as lâminas de irrigação e as dosagens de nitrogênio acumuladas. As lâminas utilizadas nas fertirrigações foram consideradas também e as precipitações que ocorreram dentro de cada período não o foram. Os totais acumulados aplicados em cada período de avaliação estão apresentadas na Tabela 6 . 
Tabela 6. Lâminas de irrigação e doses de nitrogênio, acumulados, aplicados em cada período avaliado.

\begin{tabular}{cccccccc}
\multicolumn{3}{c}{ Lâmina acumulada (mm/planta) } & \multicolumn{3}{c}{ Nitrogênio acumulado $\left(\mathrm{kg}^{-}\right.$} \\
\cline { 2 - 8 } Período & L1 & L2 & L3 & L4 & N1 & N2 & N3 \\
\hline 1 & 6,0 & 26,5 & 46,7 & 55,4 & 0,0 & 4,49 & 8,98 \\
2 & 18,0 & 58,4 & 99,2 & 116,0 & 0,0 & 13,48 & 26,95 \\
3 & 24,0 & 79,0 & 131,3 & 152,7 & 0,0 & 17,97 & 35,94 \\
4 & 33,0 & 105,7 & 175,8 & 207,2 & 0,0 & 25,29 & 50,59 \\
5 & 36,0 & 119,0 & 199,5 & 233,9 & 0,0 & 26,95 & 53,91 \\
6 & 42,0 & 140,4 & 236,3 & 276,8 & 0,0 & 29,79 & 59,57 \\
7 & 48,0 & 150,2 & 249,9 & 291,9 & 0,0 & 47,46 & 94,92 \\
8 & 66,0 & 171,2 & 273,9 & 317,1 & 0,0 & 92,38 & 184,77 \\
9 & 69,0 & 183,4 & 295,3 & 342,2 & 0,0 & 148,05 & 296,09 \\
10 & 81,0 & 212,3 & 341,1 & 394,7 & 0,0 & 184,96 & 369,92 \\
11 & 87,0 & 235,2 & 380,8 & 441,1 & 0,0 & 207,81 & 415,63 \\
12 & 87,0 & 250,2 & 411,9 & 478,4 & 0,0 & 213,48 & 426,95 \\
13 & 99,0 & 278,5 & 456,5 & 529,6 & 0,0 & 241,80 & 483,59 \\
14 & 105,0 & 302,6 & 498,7 & 578,9 & 0,0 & 253,13 & 506,25 \\
15 & 120,0 & 342,1 & 562,8 & 652,6 & 0,0 & 321,09 & 642,19 \\
16 & 129,0 & 364,7 & 599,0 & 694,2 & 0,0 & 355,08 & 710,16 \\
17 & 135,0 & 395,9 & 658,4 & 765,4 & 0,0 & 355,08 & 710,16 \\
18 & 138,0 & 404,3 & 672,1 & 781,2 & 0,0 & 366,41 & 732,81 \\
19 & 144,0 & 410,3 & 678,1 & 787,2 & 0,0 & 389,06 & 778,13 \\
\hline
\end{tabular}

\subsection{Tratos culturais}

Para evitar a competição das ervas daninhas, as mesmas foram controladas manualmente na linha de plantio a cada trinta dias e quimicamente pela aplicação de herbicida Roundap (3,5 L ha $\left.{ }^{-1}\right)$, na entrelinha de planta.

O controle de doenças e pragas foi feito com pulverizações mensais preventivas, com a aplicação de fungicida Benomyl $\left(10 \mathrm{~g} 15 \mathrm{~L}^{-1}\right)$, inseticidas Nuvracon $\left(35 \mathrm{ml}^{\left.15 \mathrm{~L}^{-1}\right) \mathrm{e}}\right.$

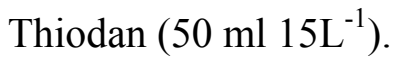




\subsection{Avaliação do desenvolvimento vegetativo}

As respostas da pupunheira aos tratamentos foram avaliadas mensalmente por medições do desenvolvimento da cultura em todas as plantas úteis de cada parcela considerando-se as seguintes características, conforme recomendação de Clement \& Bovi (2000):

a) diâmetro da planta: medido na região do colo da planta;

b) altura da planta: medida da base do tronco ao ponto de inserção da folha mais nova totalmente aberta;

c) número de perfilhos por planta;

d) número de folhas: foram contadas apenas as folhas vivas abertas, ignorando as amarelas, uma vez que estas são fotossintéticamente inativas;

e) emissão de folhas novas: foram amarradas fitas às mesmas para identificação das folhas novas emitidas pela planta desde a ultima avaliação;

f) comprimento de folha;

g) área foliar.

Assim que se iniciaram as imposições dos tratamentos, foram mensuradas todas as plantas, sendo realizadas avaliações mensais que se estenderam até o corte da planta para obtenção do palmito.

Os parâmetros altura de planta e diâmetro do estipe foram avaliados recorrendose a determinação da taxa de crescimento, que corresponde ao incremento obtido entre duas avaliações. Sendo calculada da seguinte maneira, conforme descrito por Benincasa (1988):

$$
T c=\frac{A_{2}-A_{1}}{T_{2}-T_{1}}
$$

em que:

A1 e A2 - valores reais mensurados; 
T1 e T2 - intervalo de tempo entre duas avaliações consecutivas

Os demais parâmetros número de folhas, número de perfilhos e emissão de folhas novas foram avaliados a partir do número de unidades estruturais.

\subsection{1 Área foliar}

Para estimar o IAF foi utilizado o equipamento LAI 2000 PCA (Plant Canopy analyser) desenvolvido pela Li-Cor. O LAI 2000 da Li-Cor é um aparelho composto por um sensor ótico conectado a uma pequena central de aquisição de dados. Este sensor é composto por um feixe ótico que recebe a radiação difusa que transpõem o dossel vegetativo em um ângulo total de $148^{\circ}$, um espelho e um filtro ótico que transmite parte da radiação difusa que possui comprimento de onda inferior a $490 \mathrm{~nm}$. A partir dos dados transmitidos pelo sensor, a central utiliza-se de um modelo matemático que se baseia na transmissão de luz solar pelo dossel para estimar a área foliar, IAF e a orientação foliar (Miller, 1967).

Em 15/09/2001 (499NDA), foi feita uma medida realizada no final da tarde em todos os tratamentos com uma repetição por tratamento. Foram determinadas leituras acima (A) e abaixo (B) do dossel, utilizando-se uma abertura de $90^{\circ}$. O sensor A tem a finalidade de registrar a radiação difusa recebida por cima do dossel. Com o sensor B, foram feitas três leituras em cada ponto, em duas diagonais cruzadas, compostas de quatro pontos. Cada diagonal foi passada duas vezes, invertendo a posição do ângulo de visada do sensor. Primeiramente, em sentido longitudinal e, posteriormente, em sentido transversal à fileira de planta.

\subsection{Avaliação do sistema radicular}

\subsubsection{Método indireto}


Para as avaliações do sistema radicular foi instalada uma parcela contendo oito linhas de plantio, com oito plantas em cada linha, no espaçamento de 2,0 m x 1,0 m (Figura 3(c)), optando-se pelo tratamento correspondente ao nível de 100\% da ETo. Das oito linhas de planta, três linhas centrais foram utilizadas para avaliação da distribuição do sistema radicular. Em cada planta, foram instalados tubos de acesso à sonda de nêutrons, com $1 \mathrm{~m}$ de comprimento, na linha e na entrelinha de plantas. Foram alojados quatro tubos de acesso na linha a $0,15 \mathrm{~m}, 0,30 \mathrm{~m}, 0,45 \mathrm{~m}$ e $0,6 \mathrm{~m}$ de distância do tronco da planta, mais seis na entrelinha a $0,15 \mathrm{~m}, 0,30 \mathrm{~m}, 0,45 \mathrm{~m}, 0,60 \mathrm{~m}, 0,75 \mathrm{~m}$ e $0,90 \mathrm{~m}$. E as leituras foram realizadas nas profundidades de $0,20 \mathrm{~m}, 0,40 \mathrm{~m}, 0,60 \mathrm{~m}, 0,80 \mathrm{~m}$ (Figura 4), assumindo-se que os tubos estavam posicionados na maior parte da zona radicular.

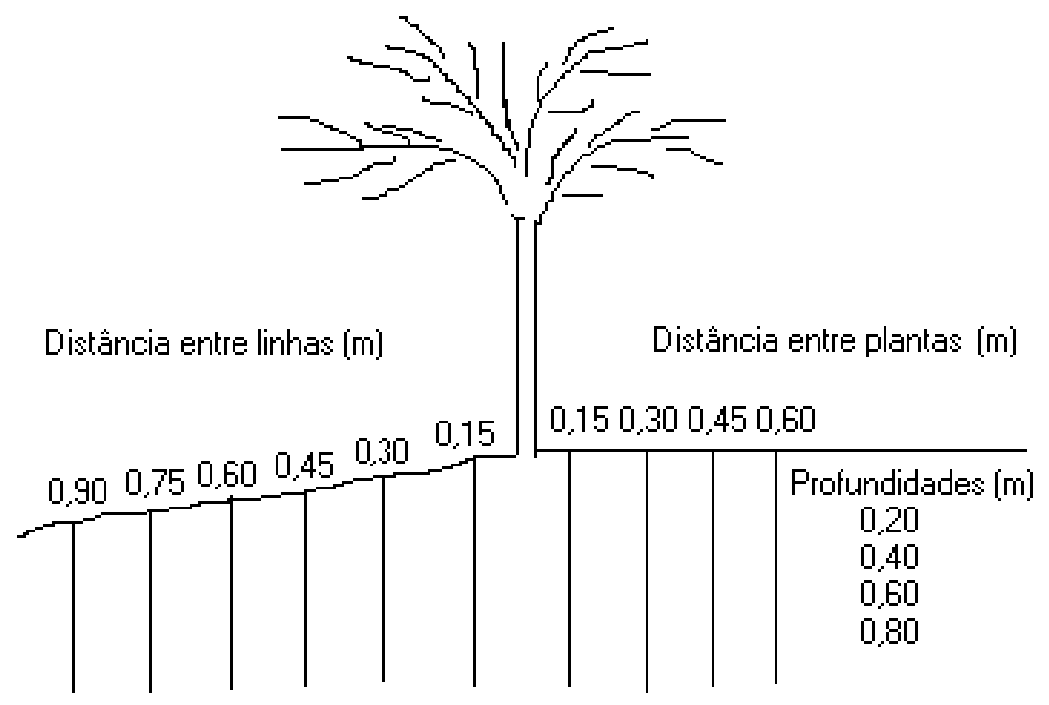

\section{Figura 4 - Esquema da instalação dos tubos de acesso na linha, entrelinha de plantas e profundidades.}

Delimitou-se uma área de $2 \mathrm{~m} \times 2 \mathrm{~m}$ a partir do centro da planta para isolar a plantas, garantindo que as mesmas recebessem somente água de irrigação. Nesta área, saturou-se toda a superfície do solo. A mesma foi coberta por uma lona plástica para evitar os efeitos da evaporação e precipitação sobre a real situação de extração de água 
pelas raízes. Após a cobertura do solo, durante quatro semanas foram realizadas medições diárias de umidade (Figura 5). Esta metodologia foi repetida a cada quatro meses. A área potencial de absorção das raízes foi estimada em função da variação de umidade entre dias subseqüentes.

O cálculo da variação de armazenamento de água nos períodos avaliados foi obtido com a média da umidade das três plantas, para cada ponto de leitura com a sonda (na linha e entrelinha), empregando a equação (4):

$$
\Delta \mathrm{Arm}=(\theta \mathrm{f}-\theta \mathrm{i}) * \mathrm{z}
$$

em que:

$\Delta$ Arm, - variação da lâmina de água armazenada na camada de solo $\left(\mathrm{cm} \mathrm{H}_{2} \mathrm{O}\right)$;

$\theta f$ - umidade média final $\left(\mathrm{cm}^{-3} \mathrm{~cm}^{-3}\right)$;

$\theta \mathrm{i}$ - umidade inicial $\left(\mathrm{cm}^{-3} \mathrm{~cm}^{-3}\right)$;

$\mathrm{z}$ - profundidade $(\mathrm{cm})$,

Assim, a variação de umidade do solo indicou os pontos em que houve maior consumo de água pela cultura tanto verticalmente (em profundidade), como horizontalmente (entrelinhas e linhas de plantas), sendo este um indicativo dos pontos (ou camadas) em que houve maior atividade radicular.

A calibração da sonda de nêutrons foi realizada na área de estudo do sistema radicular (Figuras 6a, 6b, 7a e 7b), pelo conteúdo de umidade do solo determinado gravimetricamente, nas profundidades de estudo. Foram realizadas leituras padrão e uma leitura para cada profundidade de estudo, assim como retiradas amostras gravimétricas. Os valores médios das contagens (solo/padrão) foram convertidos para umidade volumétrica pela curva de calibração específica. 


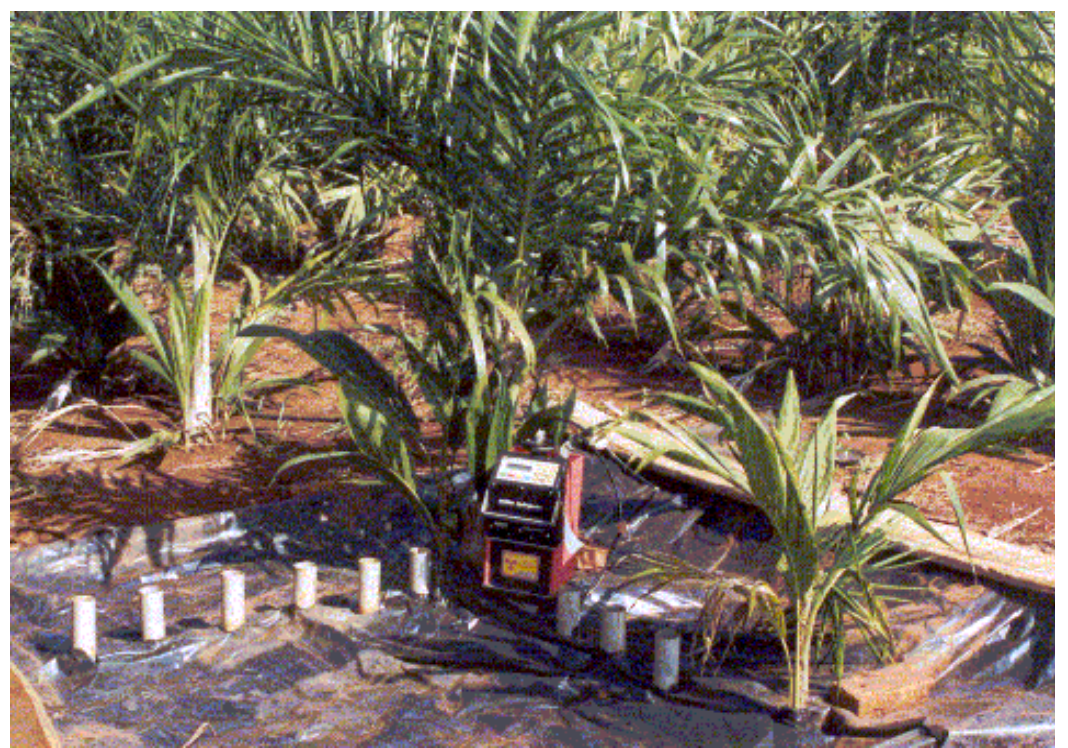

Figura 5 - Planta para estudo de sistema radicular pela variação da umidade do solo.

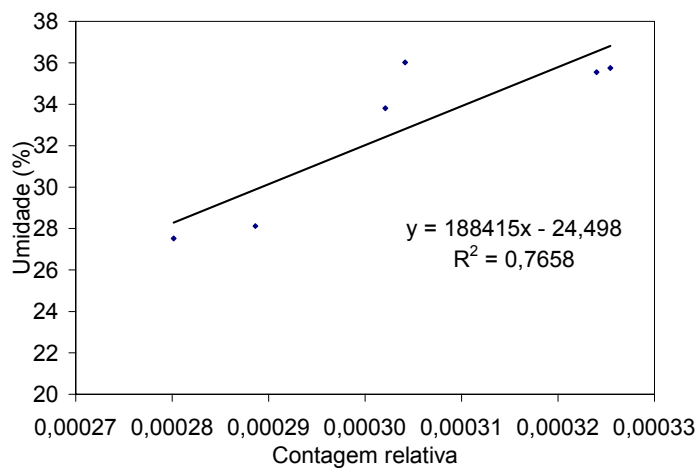

(a)

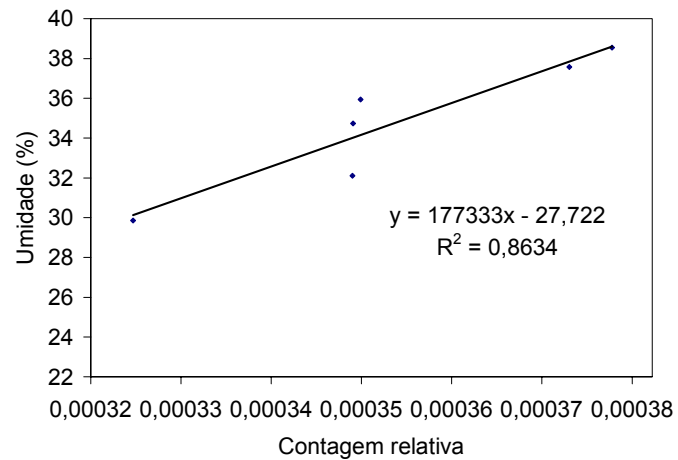

(b)

Figura 6 - Curva de calibração da sonda de nêutrons para as profundidades de 0,2m (a) e $0,4 \mathrm{~m}(\mathrm{~b})$. 


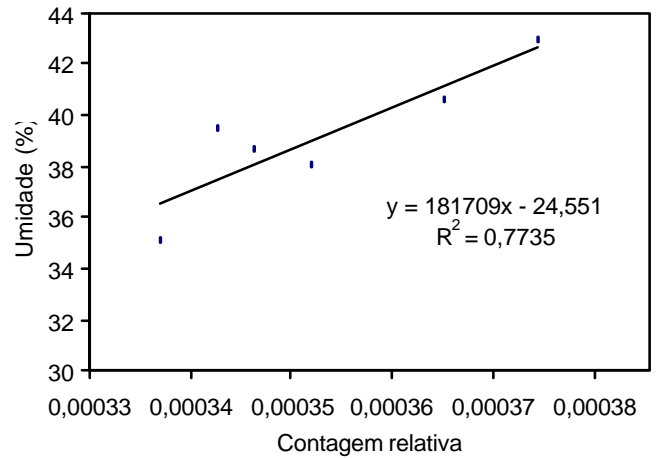

(a)

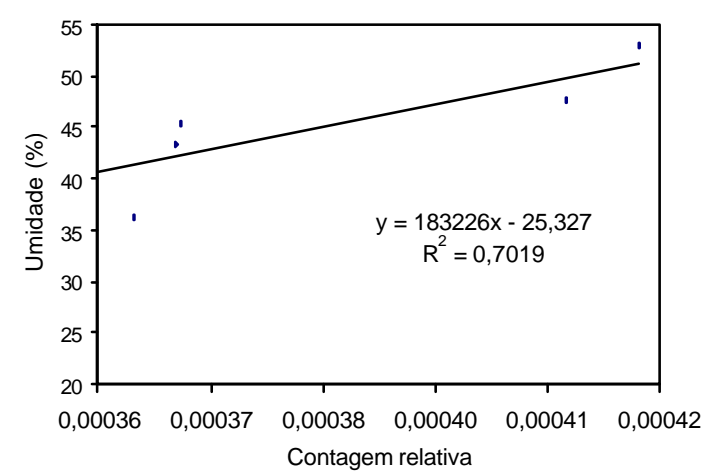

(b)

Figura 7 - Curva de calibração da sonda de nêutrons para a profundidade de 0,6 m (a) e $0,8 \mathrm{~m}(\mathrm{~b})$.

\subsubsection{Método direto}

Para o estudo do sistema radicular, pelo método direto, foram abertas trincheiras em cada planta estudada. Cada trincheira teve as dimensões de 1,4 m x 1,0 m, abrangendo uma área de 0,70 $\mathrm{m}$ de cada lado da planta, 1,0 $\mathrm{m}$ na entrelinha de planta e 1,0 m de profundidade. O perfil de solo foi lavado para exposição das raízes, completando a operação com o auxílio de um canivete. Após a completa exposição das raízes, estas foram coloridas com esmalte branco com a utilização de pincéis finos, proporcionando uma maior visualização das raízes em contraste com o solo. Em seguida, foi realizado o corte das raízes que ficaram horizontalmente para fora do perfil do solo, deixando-as com $1 \mathrm{~cm}$ de comprimento.

Estando o perfil pronto, foi colocado um telado dividido em 35 quadrículas, tendo cada uma a dimensão de $0,20 \mathrm{~m}$ x 0,20 m, totalizando uma área de $400 \mathrm{~cm}^{2}$ (Figura 8). As quadrículas foram numeradas e de cada quadrícula foi obtida uma imagem com câmera digital (Cássio QVPC 100), sendo estas analisadas pelo emprego do SIARCS (Sistema Integrado para Análise de Raízes e Cobertura do Solo), desenvolvido pela EMBRAPA. 

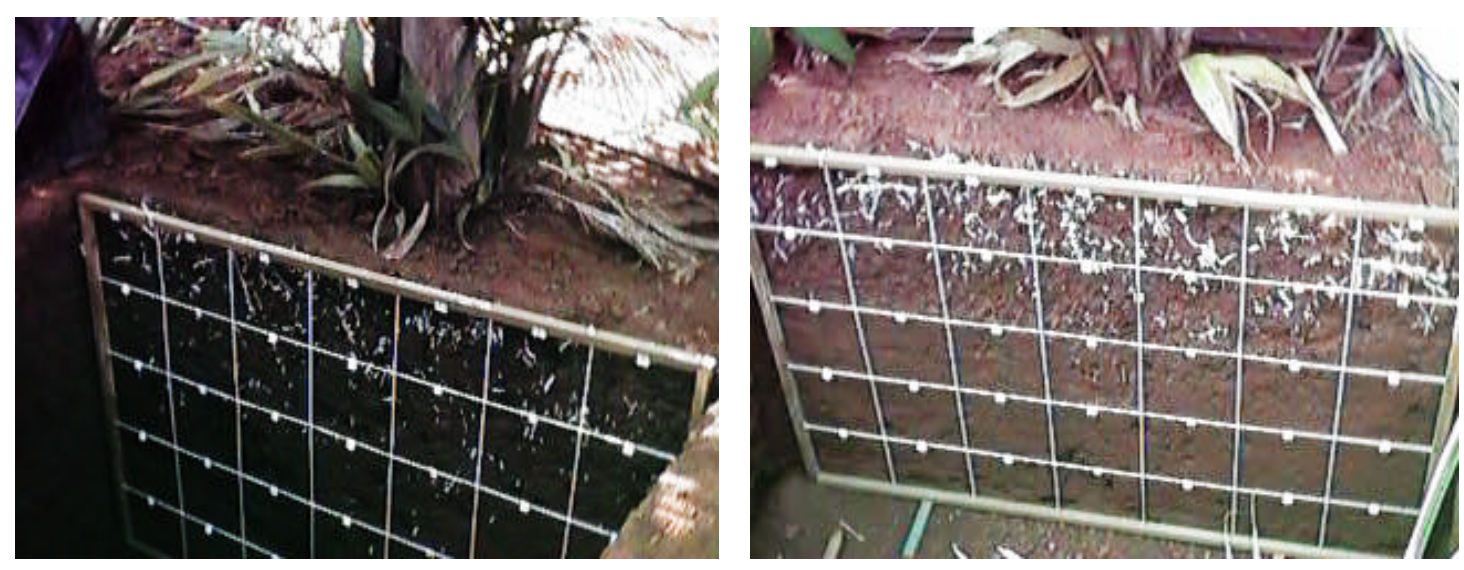

Figura 8 - Vista dos perfis do solo com as raízes pintadas e com a tela, prontos para as fotografias digitais.

Obtidas as fotografias digitalizadas, foi utilizado o programa Corel Draw 8.0, para regular o contraste e brilho das fotos, convertendo para 256 cores (8 bits). Posteriormente, empregou-se o programa SIARCS para o processamento e análise das imagens. Neste, inicialmente, delimitou-se a área de cada quadrícula $(0,20 \mathrm{~m} \times 0,20 \mathrm{~m})$ para seleção da área interna desta, que por sua vez propiciou a possibilidade de relacionar um determinado comprimento de raiz com o número de "pixels" correspondente a esta área. Em seguida, foram utilizados os comandos de TRESHOLDING, para a pintura das raízes e seleção das mesmas. A fase seguinte foi a "binarização" para transformar os 256 cores em tons de preto e branco, permitindo dessa forma a identificação dos "pixels" que representam as raízes em preto.

A quantificação das raízes foi feita recorrendo-se a histograma, que representa a frequiência das regiões claras e escuras de uma imagem. Sendo assim, o cálculo da densidade de raízes é obtido pela divisão do número de "pixels" correspondentes às raízes (que estão em preto) pelo número total de "pixels" da imagem. O resultado é expresso pela densidade de raízes presentes em $400 \mathrm{~cm}^{2}$ de solo $(0,20 \mathrm{~m} \times 0,20 \mathrm{~m})$.

Além da densidade, o programa permite mensurar o sistema radicular pela determinação do comprimento total de raízes em $400 \mathrm{~cm}^{2}$ de solo, pelo processo de 
esqueletonização de raízes, onde as raízes passam por um "afinamento", ou seja, às raízes com mais de um "pixel" de largura são transformadas, ficando com apenas um "pixel" de largura, com a espessura de uma linha. Contabilizando os "pixels" pretos restantes na imagem, obtém-se o comprimento total de raízes presentes na imagem.

\subsection{Colheita}

Segundo Bovi (1998), a colheita no Brasil é efetuada por volta dos 18 meses aos 36 meses do plantio. Essa variação ocorre em função das condições locais de cultivo. Para as condições estudadas, o corte se iniciou por volta dos 30 meses de plantio, quando as plantas estavam com 1,60 m de altura e diâmetro da planta (a $0,50 \mathrm{~m}$ de altura) variando de $0,9 \mathrm{~m}$ a $0,12 \mathrm{~m}$.

Foram realizados quatro cortes. O primeiro, em outubro/2001, quando foram cortadas $12 \%$ do total das plantas úteis (480 plantas) que atingiram altura de corte. O segundo, foi realizado aproximadamente dois meses após o primeiro, com o corte de $11 \%$ das plantas úteis. Em janeiro de 2002, foi feito mais um corte com 12\%. E, no último, realizado em fevereiro/2002, foram cortadas 15\%. Neste momento, optou-se pelo corte de todas as plantas úteis, incluindo as que ainda não apresentavam altura para corte, uma vez que existia o interesse de avaliar os efeitos dos tratamentos sobre a produtividade inicial das plantas.

Para obtenção de dados da produtividade foram realizadas medidas de peso bruto (Figura 9 a), peso total (palmito de primeira + palmito de segunda) (figura $10 \mathrm{~b}$ ) e diâmetro do palmito. 


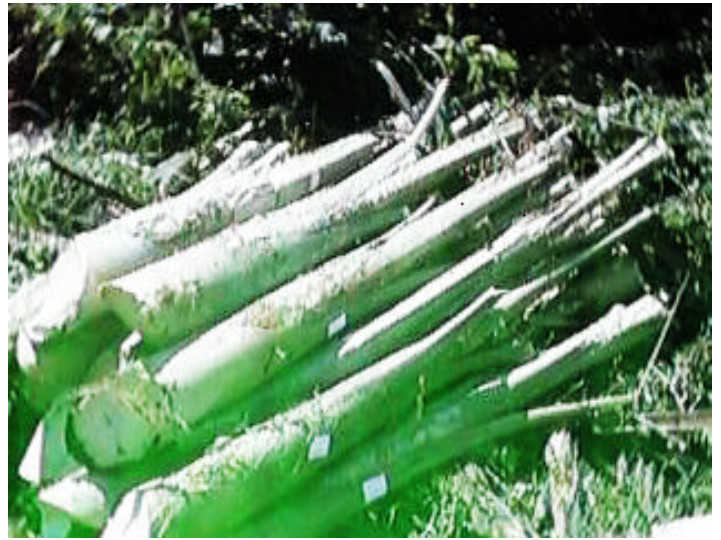

(a)

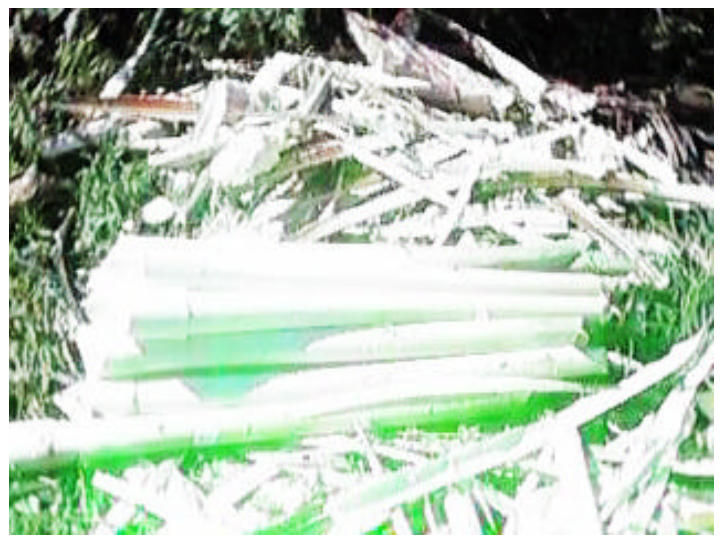

(b)

Figura 9 - (a) Estipes prontas para obtenção do peso bruto; (b) peças prontas para a retirada do palmito.

Foram considerados palmitos de primeira os toletes macios de $0,9 \mathrm{~m}$ de comprimento e sem defeitos físicos ou mecânicos. Para a produção do palmito de segunda foram contabilizadas as partes referentes ao estipe tenro ou também chamado de resíduo basal e a folha tenra, ou resíduo apical. Foram medidos os diâmetros dos palmitos na base (região do meristema apical), no meio e no ápice (região do final da bainha) (Clement \& Bovi, 2000).

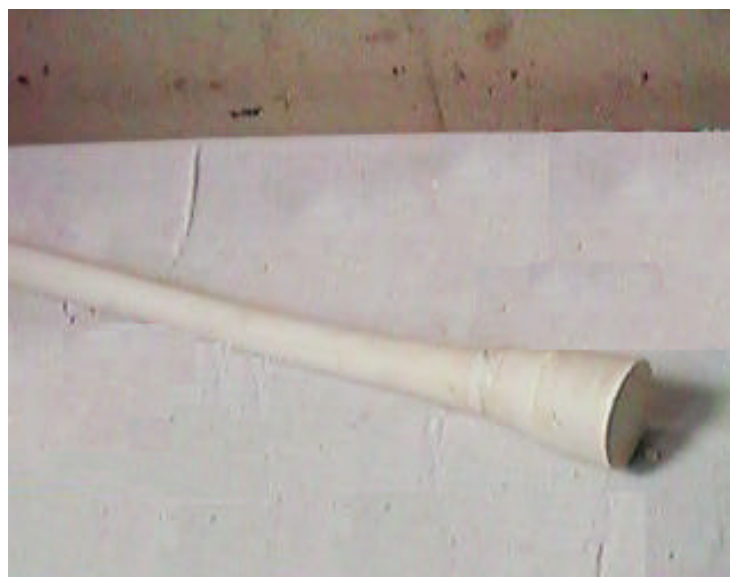

(a)

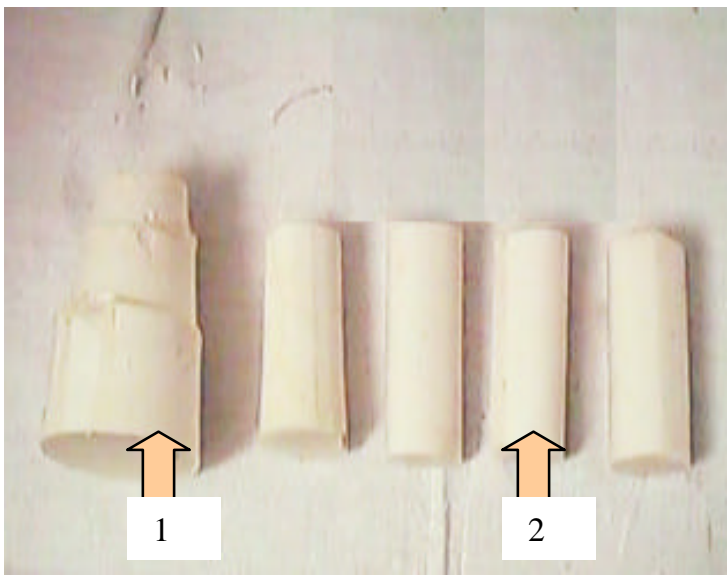

(b)

Figura 10 - (a) Peça de palmito descascada; (b) peças de palmito de primeira (1) + . palmito de segunda (2). 


\subsection{Análise estatística}

Para análise estatística das características relacionadas ao desenvolvimento de plantas foi efetuada uma análise de variância e de regressão, com o auxílio do software SAS (Statistical Analysis System 6.11). Análise esta, de experimento em blocos ao acaso, em ensaio fatorial 4 × 3 (níveis de irrigação e doses de nitrogênio) realizada para cada período de avaliação.

As Tabelas abaixo representam o esquema da análise de variância e de regressão efetuada para todos os parâmetros avaliados.

Tabela 7. Esquema da análise de variância.

\begin{tabular}{cccc}
\hline Causas de Variação & GL & QM & F \\
\hline Tratamento & IJ-1 & Vt & VT/V4 \\
Lâmina & $\mathrm{I}-1$ & V1 & V1/V4 \\
Nitrogênio & $\mathrm{J}-1$ & $\mathrm{~V} 2$ & V2/V4 \\
L x N & $(\mathrm{I}-1)(\mathrm{J}-1)$ & $\mathrm{V} 3$ & $\mathrm{~V} 3 / \mathrm{V} 4$ \\
Bloco & $\mathrm{K}-1$ & - & \\
Resíduo & $(\mathrm{IJ}-1)(\mathrm{K}-1)$ & $\mathrm{V} 4$ & \\
Total & $\mathrm{IJK}-1$ & & \\
\hline
\end{tabular}

Tabela 8. Esquema da análise de regressão.

\begin{tabular}{lccc}
\hline \multicolumn{1}{c}{ Causas de Variação } & GL & QM & F \\
\hline Linear Lâmina & 1 & V1' & V1'/V4 \\
Quadrática Lâmina & 1 & V1” & V1’/V4 \\
Linear Nitrogênio & 1 & V2' & V2'/V4 \\
Quadrática Nitrogênio & 1 & V2” & V2’/V4 \\
L x N & (I-1)(J-1) & V3 & V3/V4 \\
Tratamento & IJ-1 & Vt & \\
Bloco & K-1 & - & \\
Resíduo & (IJ-1)(K-1) & V4 & \\
Total & IJK-1 & & \\
\hline
\end{tabular}




\section{RESULTADOS E DISCUSSÃO}

\subsection{Variáveis meteorológicas}

Os dados climáticos obtidos durante a realização do experimento são apresentados na Tabela 9 e são muito importantes para melhor compreensão do desenvolvimento da cultura ao longo dos períodos observados. Verifica-se por esta tabela que no intervalo compreendido entre o $5^{\circ}$ período e $11^{\circ}$ período e a partir do $17^{\circ}$ período foram registradas temperaturas acima do valor recomendado para o maior desenvolvimento vegetativo e produtividade da pupunheira (média anual de $22^{\circ} \mathrm{C}$ (Bovi, 1998)). Além da temperatura, nestes períodos também ocorreram elevados índices de precipitação, principalmente, do 4 período ao $9^{\circ}$ período, entretanto, os valores totais no período de um ano ainda foram inferiores a $2000 \mathrm{~mm} \mathrm{ano}^{-1}$.

Dentre as variáveis meteorológicas, a temperatura é de grande importância por ser um fator ambiental que intervém em praticamente todas as funções da planta, pois, afetam tanto os processos metabólicos como os físicos. Para cada processo fisiológico da planta, há uma temperatura mínima, abaixo da qual ele não se realiza, uma temperatura ótima em que durante um certo tempo o processo atinge sua maior intensidade e uma temperatura máxima, acima da qual o processo não se realiza Costa (1994). Diotto et al. (2001), em estudo sobre a relação da influência dos parâmetros climáticos sobre a taxa de crescimento das pupunheiras, observaram que a época do ano alterava a taxa de crescimento calculada em função da altura da planta. 
Tabela 9. Valores médios mensais de temperatura (T), umidade relativa (UR), radiação global $(R G)$, velocidade do vento $\left(U_{2}\right)$ e precipitação pluviométrica total acumulada (P) registrados no período de maio/2000 a fevereiro/2002, na estação experimental, em Piracicaba, SP.

\begin{tabular}{cccccc}
\hline Períodos & $\begin{array}{c}\text { UR } \\
(\%)\end{array}$ & $\begin{array}{c}\mathrm{T} \\
\left({ }^{\circ} \mathrm{C}\right)\end{array}$ & $\begin{array}{c}\text { RG } \\
(\mathrm{J})\end{array}$ & $\begin{array}{c}\mathrm{U}_{2} \\
\left(\mathrm{~km} \mathrm{~h}^{-1}\right)\end{array}$ & $\begin{array}{c}\text { Precipitação } \\
(\mathrm{mm})\end{array}$ \\
\hline $1(01 / 05 / 00-04 / 06 / 00)$ & 74 & 18,74 & 81,05 & 1,94 & 5,30 \\
$2(05 / 06 / 00-04 / 07 / 00)$ & 71 & 19,56 & 74,74 & 1,89 & 5,20 \\
$3(05 / 07 / 00-04 / 08 / 00)$ & 72 & 16,53 & 75,40 & 2,00 & 60,40 \\
$4(05 / 08 / 00-03 / 09 / 00)$ & 68 & 19,45 & 76,33 & 2,33 & 122,90 \\
$5(04 / 09 / 00-09 / 10 / 00)$ & 73 & 22,14 & 105,09 & 2,53 & 72,90 \\
$6(10 / 10 / 00-06 / 11 / 00)$ & 69 & 25,36 & 116,08 & 2,19 & 124,70 \\
$7(07 / 11 / 00-15 / 12 / 00)$ & 77 & 23,92 & 109,31 & 2,22 & 262,30 \\
$8(16 / 12 / 00-16 / 01 / 01)$ & 81 & 24,84 & 115,97 & 2,08 & 188,30 \\
$9(17 / 01 / 01-24 / 02 / 01)$ & 75 & 26,06 & 109,42 & 1,92 & 275,10 \\
$10(25 / 02 / 01-21 / 03 / 01)$ & 82 & 25,38 & 109,16 & 1,58 & 96,10 \\
$11(22 / 03 / 01-19 / 04 / 01)$ & 77 & 24,58 & 105,93 & 1,67 & 86,80 \\
$12(20 / 04 / 01-21 / 05 / 01)$ & 73 & 20,53 & 85,87 & 1,75 & 57,30 \\
$13(22 / 05 / 01-02 / 07 / 01)$ & 78 & 18,76 & 67,67 & 1,64 & 29,40 \\
$14(03 / 07 / 01-31 / 07 / 01)$ & 77 & 18,69 & 72,23 & 1,42 & 27,20 \\
$15(01 / 08 / 01-04 / 09 / 01)$ & 72 & 20,76 & 95,30 & 1,89 & 44,20 \\
$16(05 / 09 / 01-09 / 10 / 01)$ & 65 & 21,38 & 99,45 & 2,03 & 132,80 \\
$17(10 / 10 / 01-13 / 11 / 01)$ & 67 & 23,49 & 119,69 & 2,53 & 176,10 \\
$18(14 / 11 / 01-11 / 12 / 01)$ & 69 & 24,87 & 114,73 & 2,14 & 98,00 \\
$19(12 / 12 / 01-22 / 01 / 02)$ & 83 & 24,5 & 102,15 & 1,97 & 204,2 \\
$20(23 / 01 / 02-18 / 02 / 02)$ & 88 & 23,9 & 98,06 & 1,83 & 320,2 \\
\hline
\end{tabular}

Somando-se os valores de precipitação, presentes na Tabela 9 e referentes ao período de maio/2000 a abril/2001, chega-se a um total anual de 1398,1 mm. De maio/2001 a fevereiro/2002 o total (período de 10 meses) foi de 1238,3 mm. Estes valores são inferiores ao recomendado para a cultura (Bovi, 1998), de forma que ocorra tanto um maior desenvolvimento vegetativo, como um maior peso em palmito por planta. Esses dados confirmam a necessidade de irrigação complementar quando cultivada nas condições agroclimatológicas de Piracicaba, SP. Além disso, a distribuição temporal das chuvas afetaria a fase inicial de estabelecimento das mudas no campo, principalmente, nos meses de maio a junho/2000, cujos índices de precipitação foram muito baixos. O mesmo ocorreu no período de abril a agosto/2001, conforme se observa 
na Figura 11. A maior concentração das chuvas registrou-se no período de novembro/2000 a março/2001, período este em que foram aplicadas as menores lâminas de irrigação (Tabela 10).

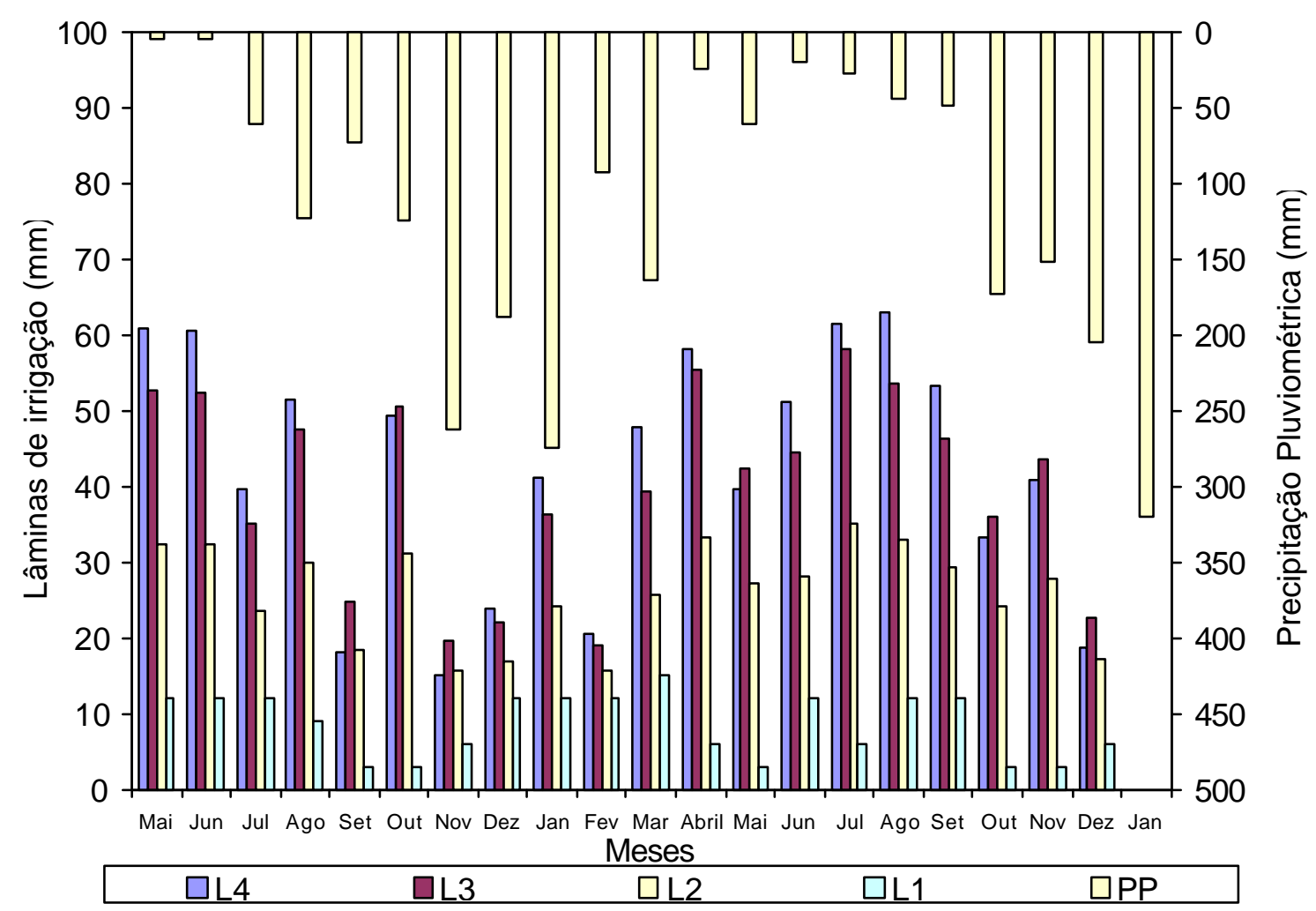

Figura 11 - Valores mensais de precipitação pluviométrica e lâminas de água aplicada para os quatro níveis de irrigação estabelecidos.

\subsection{Manejo de água}

De maio/1999 a abril/2000, primeiro ano da cultura no campo e que corresponde à fase de pegamento das mudas e estabelecimento da cultura no campo, foi aplicada uma lâmina de água uniforme para toda a área (100\%ETo). A partir de maio/2000 começaram a ser aplicados os tratamentos com lâminas de irrigação diferenciadas. Os totais aplicados para cada tratamento, em todos os períodos avaliados, são apresentados na Tabela 10, onde verifica-se os valores de $784,2 \mathrm{~mm}, 678,1 \mathrm{~mm}$ e $410,3 \mathrm{~mm}$, para os 
tratamentos L2, L3 e L4, respectivamente. A esses totais estão inclusos as lâminas referentes à fertirrigação. O tratamento L1 (testemunha) recebeu água somente via fertirrigação, sendo aplicada uma lâmina de $3 \mathrm{~mm}$ em cada fertirrigação efetuada, num total de 144,0 mm em todo o período correspondente à fertirrigação.

Nos meses de janeiro e fevereiro/2002 não foram aplicados os tratamentos referentes às lâminas de irrigação, devido ao alto índice de precipitação pluviométrica que ocorreu nesse período. Foram feitas somente duas fertirrigações no mês de janeiro, completando a quantidade de adubação nitrogenada necessária até o momento em que seria feito o corte final das plantas, para avaliação de produtividade.

Tabela 10. Lâmina de irrigação aplicada $(\mathrm{mm})$ para os tratamentos L1 (Testemunha), L2 (50\%ETo), L3 (100\%ETo) e L4 (120\% ETo) nos períodos compreendidos entre maio/2000 a dezembro/2002.

\begin{tabular}{|c|c|c|c|c|}
\hline \multirow[b]{2}{*}{ Período } & \multicolumn{4}{|c|}{ Lâmina Aplicada (mm planta ${ }^{-1}$ período $\left.^{-1}\right)$} \\
\hline & L1 & L2 & L3 & L4 \\
\hline 1 & 6 & 26,5 & 46,7 & 55,4 \\
\hline 2 & 12 & 31,9 & 52,5 & 60,6 \\
\hline 3 & 6 & 20,6 & 32,1 & 36,7 \\
\hline 4 & 9 & 26,7 & 44,5 & 51,5 \\
\hline 5 & 3 & 13,3 & 23,7 & 26,7 \\
\hline 6 & 6 & 21,4 & 36,8 & 42,9 \\
\hline 7 & 6 & 9,8 & 13,6 & 15,1 \\
\hline 8 & 18 & 21,0 & 24,0 & 25,2 \\
\hline 9 & 3 & 12,2 & 21,4 & 25,1 \\
\hline 10 & 12 & 28,9 & 45,7 & 52,5 \\
\hline 11 & 6 & 22,9 & 39,8 & 46,4 \\
\hline 12 & 0 & 15,1 & 31,1 & 37,3 \\
\hline 13 & 12 & 28,3 & 44,6 & 51,1 \\
\hline 14 & 6 & 24,1 & 42,2 & 49,3 \\
\hline 15 & 15 & 39,5 & 64,1 & 73,7 \\
\hline 16 & 9 & 22,6 & 36,2 & 41,7 \\
\hline 17 & 6 & 31,2 & 59,4 & 71,2 \\
\hline 18 & 3 & 8,3 & 13,7 & 15,8 \\
\hline 19 & 6 & 6,0 & 6,0 & 6,0 \\
\hline Total & 144,0 & 410,3 & 678,1 & 784,2 \\
\hline
\end{tabular}


A Figura 12 apresenta a variação do potencial mátrico, estimado por meio de tensiometria digital de punção nos tensiômetros instalados em L2, L3 e L4.As determinações foram efetuadas no mês de outubro/2000, para que se possa verificar como foi a resposta do solo, em termos de potencial, em relação às lâminas de irrigação aplicadas nos diferentes tratamentos.

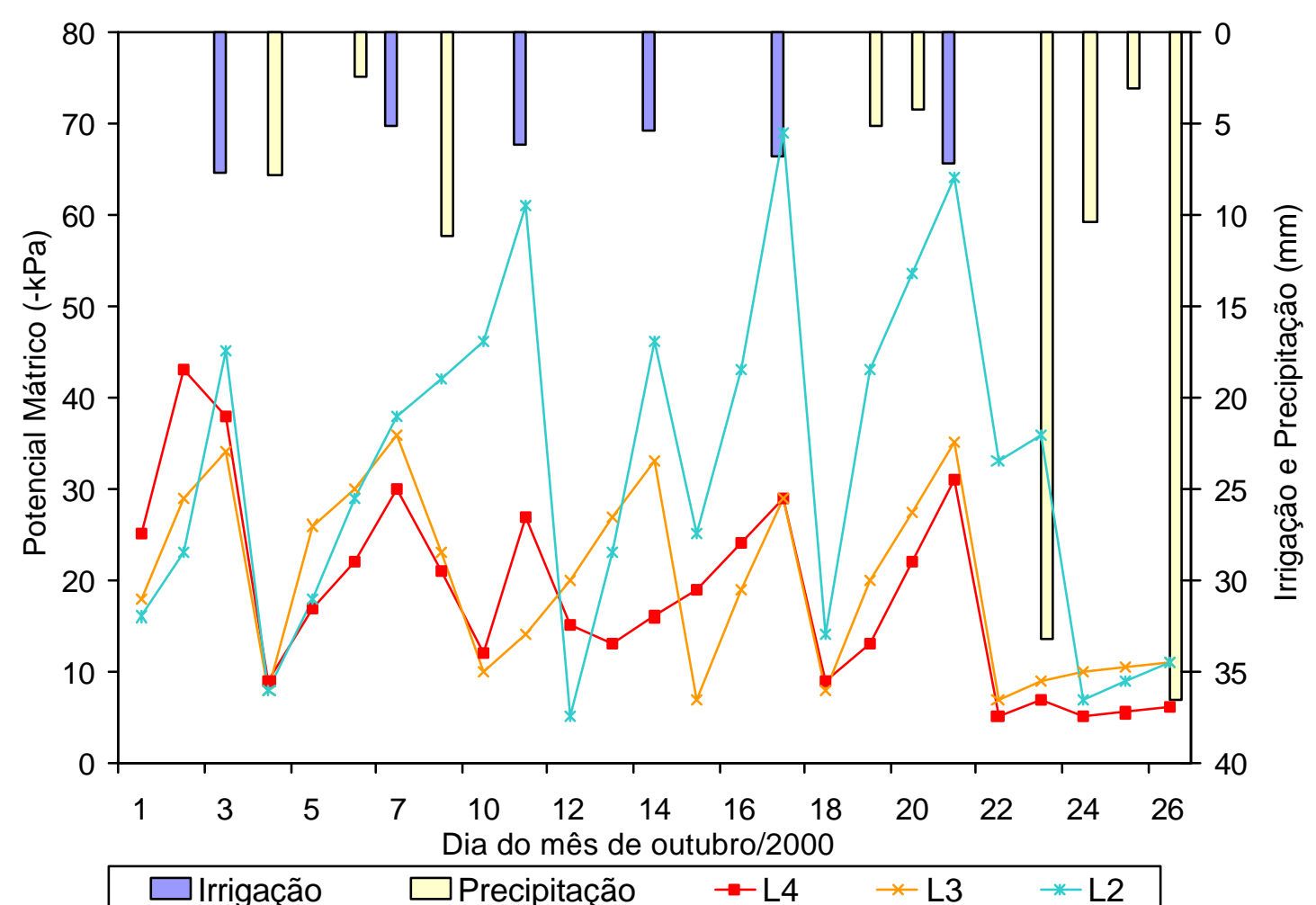

Figura 12 - Valores de potencial mátrico dos tensiômetros instalados em L2, L3 e L4, irrigação e precipitação que ocorreram em outubro/2000.

Os tensiômetros instalados nas parcelas que receberam L3 (100\%ETo) foram utilizados para determinar o momento das irrigações. Toda vez que os tensiômetros instalados a $0,15 \mathrm{~m}$ de profundidade atingiam um potencial de $30 \mathrm{kPa}$, era feita uma irrigação, acarretando em diminuição nos valores dos potenciais para $10 \mathrm{kPa}$, aproximadamente (Figura 12).

O comportamento do potencial nátrico para L3 foi semelhante a L4. Entretanto, no momento das irrigações, os valores em L4 eram inferiores aos obtidos em L3, 
justificados pela maior lâmina de irrigação aplicada, resultando também em menores variações nas leituras. Para L2, verifica-se que no momento das irrigações, seus valores de potencial eram bem superiores a L3 e L4, chegando, em alguns momentos, a registrar potenciais acima da capacidade de leitura do tensiômetro. Isto ocorria em função de uma menor lâmina de irrigação aplicada (50\%ETo). Após as irrigações, os valores de potenciais não abaixavam muito e, depois de poucos dias, seus valores subiam novamente.

Em relação à precipitação pluviométrica, nota-se que as quantidades (mm) referentes ao período estudado, até o dia 20/10/2001 (Figura 12), foram pequenas, não influenciando as leituras de potenciais registrados nos tensiômetros. O que é possível observar é uma defasagem entre a quantidade de água que cai e a que chega ao solo, devido ao processo de interceptação da água da chuva pela copa da planta. Somente quando ocorrem precipitações elevadas, como aconteceu no dia 23, é que os potenciais mátricos registrados em L2 abaixaram até um valor de igualdade a L4 e L3.

Para o tratamento L1 (testemunha), que recebeu água somente via fertirrigação, não foi possível acompanhar a variação do potencial mátrico. Afinal, os valores obtidos entre as irrigações eram superiores à capacidade de funcionamento do tensiômetro.

\subsection{DISTRI BUI ÇÃO ESPACI AL DO SI STEMA RADI CULAR EM FUNÇÃO DA LÂMI NA DE IRRI GAÇÃO}

Foi feita uma análise da distribuição do sistema radicular da cultura, para avaliar o efeito das lâminas de irrigação sobre ela. Optou-se por fixar a dosagem de nitrogênio em $200 \mathrm{~kg} \mathrm{ha}^{-1} \mathrm{ano}^{-1}$ (N2), em função de alguns estudos preliminares, quando foi constatado que não houve diferença estatística entre N3 (400 kg ha ${ }^{-1}$ ano $^{-1}$ de N) e N2 (200 $\mathrm{kg} \mathrm{ha}^{-1}$ ano $\left.^{-1}\right)$ para os diferentes parâmetros de crescimento avaliados.

Os resultados obtidos são apresentados na forma de gráficos de contorno, onde a estipe de planta está localizada na coordenada $(0,0)$ e que representam a distribuição espacial da área $\left(\mathrm{cm}^{2}\right.$ de raiz/400 $\mathrm{cm}^{2}$ de solo) e do comprimento ( $\mathrm{cm}$ de raiz/400 $\mathrm{cm}^{2}$ de solo) de raízes (Figuras 13 e 14). 

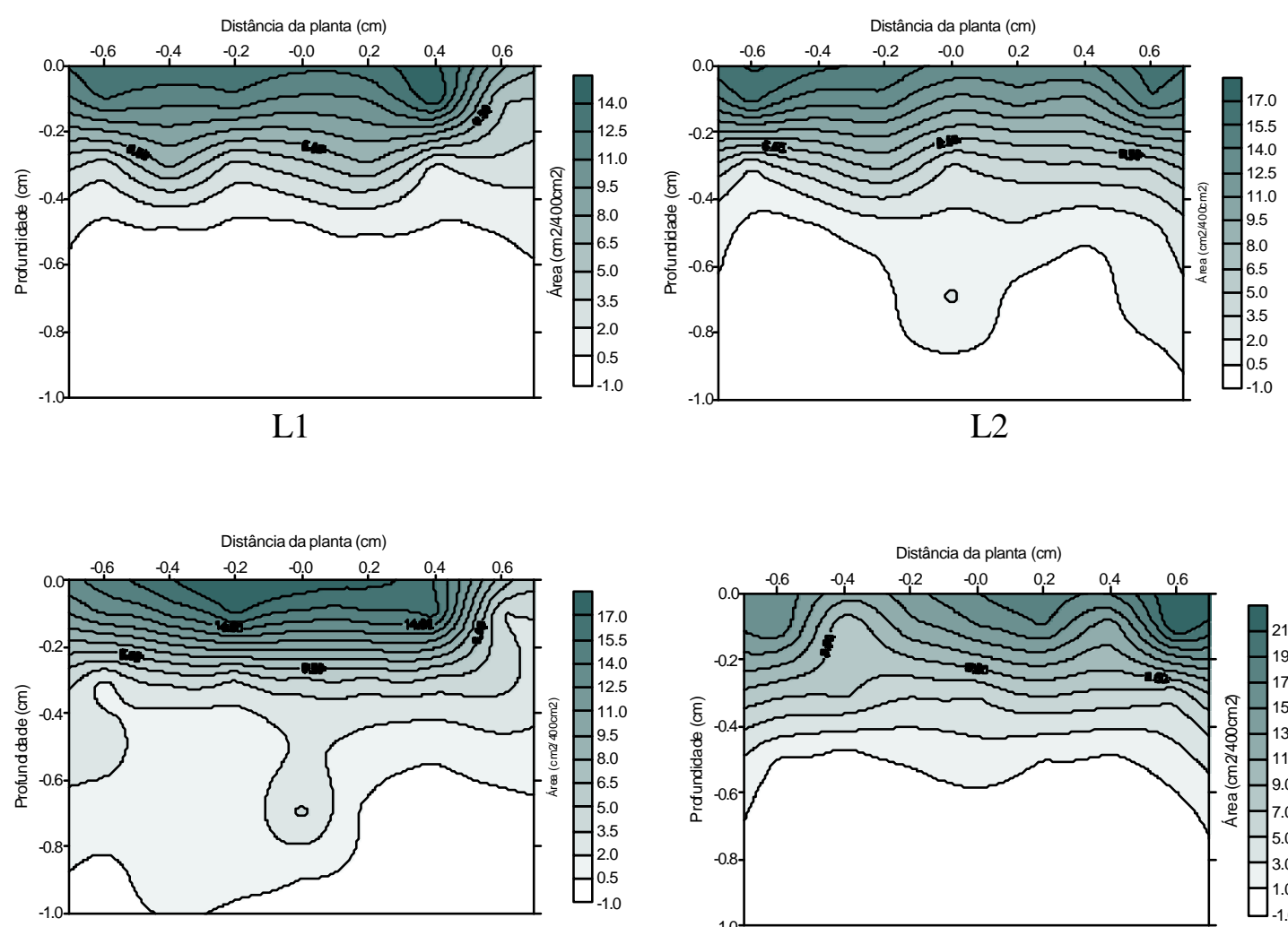

L3

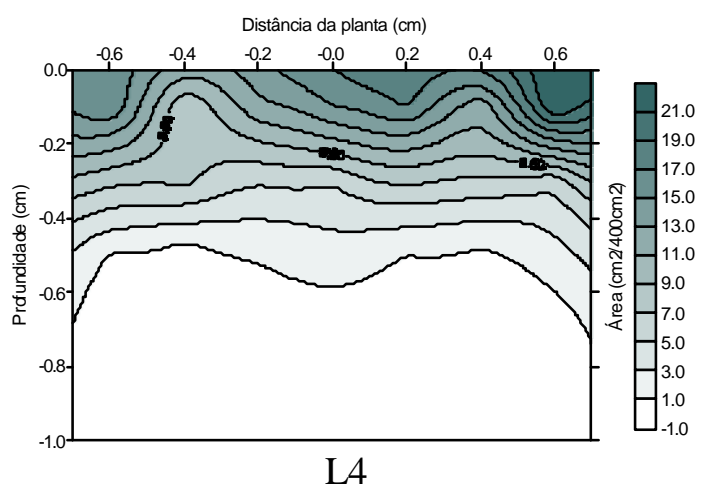

Figura 13 - Distribuição espacial da área de raízes $\left(\mathrm{cm}^{2}\right.$ de raiz/400 $\mathrm{cm}^{2}$ de solo) da pupunheira em função das lâminas de irrigação L1, L2, L3 e L4, fixando N2, aplicadas por gotejamento.

Analisando a distribuição da área de raízes (Figura 13), verifica-se que para a lâmina L4, ocorreu uma maior concentração até a profundidade de 0,2 m, com variações de $10 \mathrm{~cm}^{2}$ de raiz/400 $\mathrm{cm}^{2}$ de solo a $22 \mathrm{~cm}^{2}$ de raiz/400 $\mathrm{cm}^{2}$ de solo. Cabe destacar que estes são os maiores valores obtidos de área de raiz, quando comparados às demais lâminas de irrigação aplicadas. Apesar dessa maior distribuição de raízes se concentrar mais superficialmente $(0,20 \mathrm{~m})$, até a profundidade de $0,60 \mathrm{~m}$, ainda notou-se a presença de certa quantidade de raiz (de $0,55 \mathrm{~cm}^{2}$ de área de raiz/400 $\mathrm{cm}^{2}$ de solo até $8,5 \mathrm{~cm}^{2}$ de área de raiz/400 $\mathrm{cm}^{2}$ de solo). 
Para as lâminas L2 e L3, o comportamento da distribuição da área de raízes foi semelhante. A maior concentração também foi até a profundidade de $0,20 \mathrm{~m}$. Seus valores variaram igualmente de $6,5 \mathrm{~cm}^{2}$ de área raiz/400 $\mathrm{cm}^{2}$ de solo a $17 \mathrm{~cm}^{2}$ de área raiz/400 $\mathrm{cm}^{2}$ de solo. Na parte central da área estudada, nas coordenadas que se seguiam abaixo da localização do estipe da planta, verificou-se a presença de raízes até $0,80 \mathrm{~m}$ de profundidade. Menores densidades de raízes $\left(0,50 \mathrm{~cm}^{2}\right.$ de raiz/400 $\mathrm{cm}^{2}$ de solo a $6,5 \mathrm{~cm}^{2}$ de raiz/400 $\mathrm{cm}^{2}$ de solo) foram ainda observadas até a profundidade de aproximadamente, 0,8 m para L2 e estenderam-se até 1,0 m em L3.

As menores variações, de $0,5 \mathrm{~cm}^{2}$ de raiz/400 $\mathrm{cm}^{2}$ de solo a $14 \mathrm{~cm}^{2}$ de raiz/400 $\mathrm{cm}^{2}$ de solo, ocorreram em L1. Mais uma vez, com uma maior concentração superficial até a profundidade de $0,2 \mathrm{~m}$ aproximadamente $\left(6,5 \mathrm{~cm}^{2}\right.$ de raiz/400 $\mathrm{cm}^{2}$ de solo a $14 \mathrm{~cm}^{2}$ de raiz/400 $\mathrm{cm}^{2}$ de solo). Porém, em L1, a distribuição radicular se mostrou mais superficial, alcançando somente até a profundidade de $0,50 \mathrm{~cm}$. Esta distribuição mais superficial ocorreu graças às condições de estresse hídrico à qual a planta estava submetida. Afinal, L1 recebeu uma pequena lâmina de água somente quando fertirrigada e também porque as plantas presentes neste tratamento apresentaram um crescimento inferior em relação aos demais tratamentos. Ou seja, um menor desenvolvimento radicular pode estar associado ao menor crescimento da parte aérea. No caso de L3, além da água fornecida pela fertirrigação, ainda foram aplicadas as lâminas referentes ao tratamento (50\%ETo), resultando em um estresse hídrico menos intenso que em L3, não comprometendo tanto o desenvolvimento da parte aérea e estimulando um maior aprofundamento do sistema radicular. Cintra et al. (1993), em estudo sobre a avaliação da distribuição do sistema radicular de coqueiro gigante, observaram diferença na distribuição das raízes finas em profundidade, entre períodos secos e chuvosos, sinalizando a tendência de aprofundamento do sistema radicular quando submetido a estresse hídrico.

A Figura 14 ilustra a distribuição do comprimento de raízes $\left(\mathrm{cm}\right.$ de raiz/400 $\mathrm{cm}^{2}$ de solo). Por esta figura, é possível observar que as variações nos valores de comprimento de raiz foram iguais para L4, L3 e L2, ficando na faixa de $3 \mathrm{~cm}$ de raiz/400 $\mathrm{cm}^{2}$ de solo a $75 \mathrm{~cm}$ de raiz/400 $\mathrm{cm}^{2}$ de solo. O que se distinguiu entre esses tratamentos 
foi a distribuição do comprimento nas camadas de solo estudadas e esta distribuição foi semelhante a que ocorreu para densidade de raiz. Para L1, esta variação foi menor, com valores em torno de $3 \mathrm{~cm}$ de raiz/400 $\mathrm{cm}^{2}$ de solo a $59 \mathrm{~cm}$ de raiz/400 $\mathrm{cm}^{2}$ de solo por $\mathrm{m}$ de comprimento.

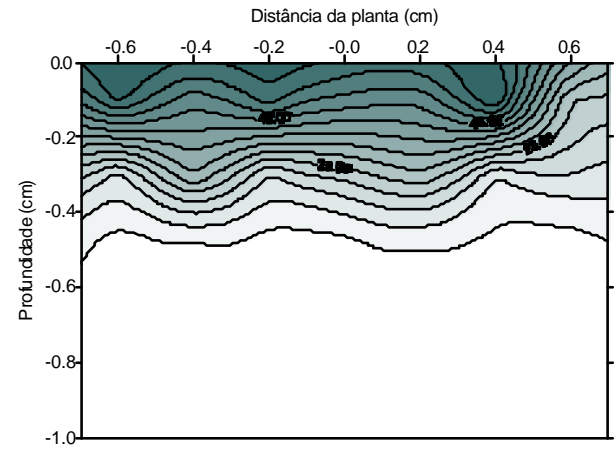

L1

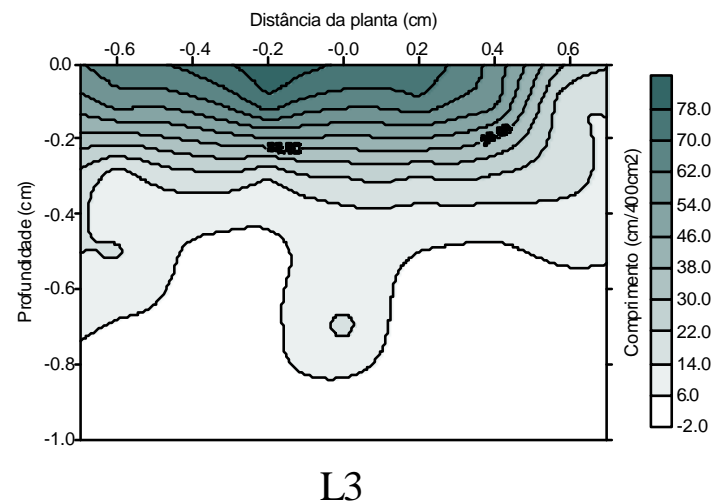

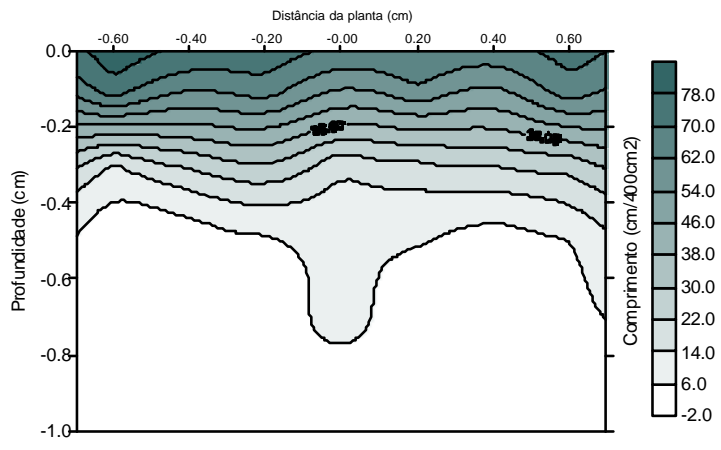

L2

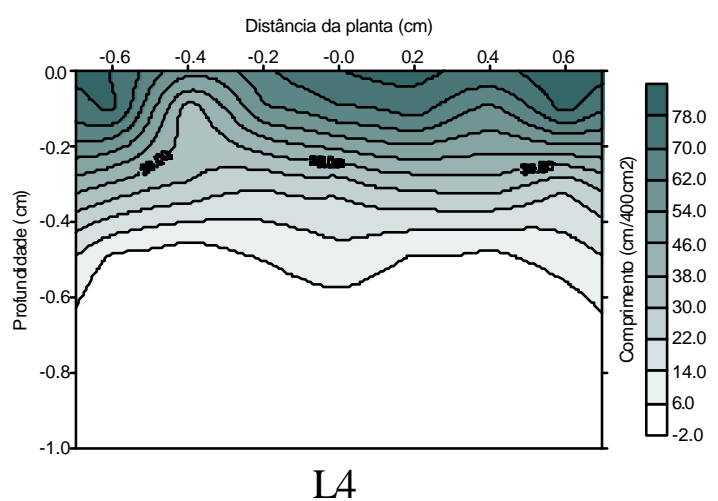

Figura 14 - Distribuição espacial do comprimento de raízes $\left(\mathrm{cm}^{2}\right.$ de raiz/400 $\mathrm{cm}^{2}$ de solo) da pupunheira em função das lâminas de irrigação L1, L2, L3 e L4, fixando N2, aplicadas por gotejamento.

As Tabelas abaixo (11 e 12) representam a distribuição percentual da área e do comprimento de raiz nas camadas do solo (de 0,0 m até 1,0 m). É possível observar, em termos de percentual de distribuição, um comportamento semelhante para área e comprimento de raízes. 
Tabela 11. Distribuição percentual da área de raiz da pupunheira, em profundidade, para as lâminas de irrigação aplicadas.

\begin{tabular}{cccccc}
\hline \multirow{2}{*}{ Lâminas } & \multicolumn{5}{c}{ Área em profundidade $(\%)$} \\
& $0-0,2 \mathrm{~m}$ & $0,2-0,4 \mathrm{~m}$ & $0,4-0,6 \mathrm{~m}$ & $0,6-0,8 \mathrm{~m}$ & $0,8-1,0 \mathrm{~m}$ \\
\hline L1 & 72,2 & 25,6 & 1,6 & 0,6 & 0,0 \\
L2 & 68,4 & 23,5 & 5,0 & 2,9 & 0,2 \\
L3 & 67,0 & 18,7 & 7,8 & 4,8 & 1,7 \\
L4 & 65,6 & 29,0 & 5,3 & 0,0 & 0,0 \\
\hline
\end{tabular}

Tabela 12. Distribuição percentual do comprimento de raiz da pupunheira, em profundidade, para as lâminas de irrigação aplicadas.

\begin{tabular}{cccccc}
\hline \multirow{2}{*}{ Lâminas } & \multicolumn{5}{c}{ Comprimento em profundidade (\%) } \\
& $0-0,2 \mathrm{~m}$ & $0,2-0,4 \mathrm{~m}$ & $0,4-0,6 \mathrm{~m}$ & $0,6-0,8 \mathrm{~m}$ & $0,8-1,0 \mathrm{~m}$ \\
\hline L1 & 73,0 & 25,0 & 1,2 & 0,7 & 0,0 \\
L2 & 69,2 & 23,5 & 4,6 & 2,4 & 0,2 \\
L3 & 65,2 & 19,8 & 8,3 & 4,9 & 1,8 \\
L4 & 65,1 & 29,5 & 5,5 & 0,0 & 0,0 \\
\hline
\end{tabular}

Pela Tabela 11, destaca-se que uma grande percentagem da área de raiz na camada de 0 m-0,2 m, em torno de 72,2 \%, 68,4\%, 67,0\% e 65,6\%, para L1, L2, L3 e L4, respectivamente. Todos esses tratamentos apresentaram uma distribuição bastante superficial, com grande parte da densidade e comprimento de raízes localizadas nesta camada e redução acentuada nas camadas seguintes. Estes resultados estão de acordo com os observados por Morales \& Vargas (1990). O valor obtido pelos autores é até superior, com $75 \%$ das raízes da planta estudada localizadas nos primeiros $0,2 \mathrm{~m}$ de profundidade. Bassoi et al. (1998), semelhantemente, afirmaram que raízes de todos os diâmetros apresentaram uma maior concentração a 0,0-0,2 m de profundidade, com redução bastante significativa na distribuição para as demais camadas.

De 0,2 m-0,4 m, observa-se uma concentração também elevada, quando comparada com as demais camadas do solo. E, de acordo com os autores acima mencionados, ocorreu uma redução drástica na concentração das raízes abaixo de $0,4 \mathrm{~m}$ de profundidade. Sendo assim, em média 97,8 \%, $92 \%, 85,7 \%$ e 94,6\% das raízes estavam distribuídas até a profundidade de 0,4 m, para L1, L2, L3 e L4, 
respectivamente. Assim, a maior concentração das raízes da pupunheira, encontra-se numa profundidade de 0,4 m a partir do centro da planta (Ferreira et al., 1980; Morales \& Vargas, 1990). Verifica-se que em L1 (testemunha) ocorreu a maior distribuição de raízes, quando comparados aos demais tratamentos. No entanto, sua distribuição se limita até a profundidade de $0,8 \mathrm{~m}$, com um percentual muito pequeno na camada de 0,6 m a 0,8 m. Já em L2 e L3, foi observado uma distribuição maior nas camadas de 0,4 m0,6 m e 0,6 m 0,8 m, chegando até a profundidade de 1,0 m. Em L2 (50\% ETo), o sistema radicular se aprofundou mais em função de estresse hídrico. Para a lâmina 3 (100\% ETo), constatou-se um sistema radicular mais profundo, chegando até a profundidade de $1,0 \mathrm{~m}$. É possível inferir que, talvez, este tenha sido o tratamento que propiciou um melhor desenvolvimento em área e comprimento do sistema radicular da cultura.

No caso de L4, o sistema radicular não foi tão profundo, estando localizado até a profundidade máxima de 0,6 m. Isto pode ter ocorrido devido à grande quantidade de água aplicada (120\% ETo) e do tipo de solo (argiloso) em que foi aplicado este tratamento, proporcionando uma condição de umidade elevada nas camadas superficiais do solo. Cintra et al. (1993) verificaram que após o período chuvoso $80 \%$ do sistema radicular do coqueiro se encontrava na camada de $0,1 \mathrm{~m}$ a 0,5 m. Enquanto que, após o período seco, este percentual diminuiu para $60 \%$, o que representou, neste período, uma redução de $20 \%$ a mais de raízes abaixo de $0,5 \mathrm{~m}$.

Lateralmente, foram analisadas as distribuições das raízes até a distância de 0,6m a partir do estipe da planta, apresentando uma distribuição mais uniforme quando comparadas com sua distribuição em profundidade, tanto para área como comprimento (Tabelas 13 e 14). As percentagens de distribuição para área até a distância de 0,4 m são de $45,18 \%, 42,84 \%, 54,32 \%$ e 56,67 \%, para L1, L2, L3 e L4, respectivamente. As maiores percentagens foram obtidas para os tratamentos que receberam as maiores lâminas de irrigação (L3 e L4). Morales \& Vargas (1990), observaram que 73,69\% das raízes estão distribuídas num raio e profundidade de $0,4 \mathrm{~m}$ a partir do centro da planta. Já, Pomier \& Bonneau (1987), trabalhando com coqueiros, discutem a natureza 
dinâmica da distribuição do sistema radicular, que é, na maioria das vezes, controlada pelo tipo de solo, condições de umidade, práticas culturais e pelas diferenças varietais.

Dos 0,4 m - 0,6 m foi encontrada uma maior concentração para L4 e L2 (42,74 $\%$ e 32,35\%). Isto está bem visível nas Figuras 13 e 14. O que pode ter ocorrido é uma sobreposição das raízes das plantas vizinhas, devido ao limitado espaçamento de $1,0 \mathrm{~m}$ entre plantas. Ferreira et al. (1980) argumentam que o fato das pupunheiras crescerem numa linha com espaçamento entre palmeiras, inferior à distância atingida pelo sistema radicular das plantas, isto pode influenciar os resultados obtidos.

Tabela 13. Distribuição percentual da área de raiz da pupunheira, em função da distância lateral da planta, para as lâminas de irrigação aplicadas.

\begin{tabular}{cccc}
\hline \multirow{2}{*}{ Lâminas } & \multicolumn{3}{c}{ Área em profundidade (\%) } \\
& $0-0,2 \mathrm{~m}$ & $0,2-0,4 \mathrm{~m}$ & $0,4-0,6 \mathrm{~m}$ \\
\hline L1 & 21,71 & 23,47 & 12,29 \\
L2 & 21,87 & 21,97 & 32,25 \\
L3 & 25,57 & 28,75 & 12,71 \\
L4 & 30,85 & 25,82 & 42,74 \\
\hline
\end{tabular}

Tabela 14. Distribuição percentual do comprimento de raiz da pupunheira, em função da distância lateral da planta, para as lâminas de irrigação aplicadas.

\begin{tabular}{cccc}
\hline \multirow{2}{*}{ Lâminas } & \multicolumn{3}{c}{ Comprimento em profundidade (\%) } \\
& $0-0,2 \mathrm{~m}$ & $0,2-0,4 \mathrm{~m}$ & $0,4-0,6 \mathrm{~m}$ \\
\hline L1 & 21,30 & 23,44 & 12,65 \\
L2 & 23,49 & 23,07 & 35,18 \\
L3 & 25,59 & 24,50 & 13,44 \\
L4 & 29,62 & 28,99 & 38,73 \\
\hline
\end{tabular}




\subsection{Análise do desenvolvimento vegetativo de plantas}

As avaliações de crescimento foram realizadas mensalmente, durante o período compreendido entre maio/2000 a fevereiro/2002, com variações de dias por período, entre 28 e 42 dias, conforme tabela abaixo (Tabela 15).

Tabela 15. Períodos de avaliação das características em estudo, número de dias do período (NDP) e número de dias acumulados (NDA), após o início da aplicação dos tratamentos.

\begin{tabular}{ccc}
\hline Períodos & N D P & N D A \\
\hline Abril/2000 & 0 & 0 \\
$1(01 / 05 / 00-04 / 06 / 00)$ & 35 & 35 \\
$2(05 / 06 / 00-04 / 07 / 00)$ & 29 & 64 \\
$3(05 / 07 / 00-04 / 08 / 00)$ & 32 & 96 \\
$4(05 / 08 / 00-03 / 09 / 00)$ & 30 & 126 \\
$5(04 / 09 / 00-09 / 10 / 00)$ & 36 & 162 \\
$6(10 / 10 / 00-06 / 11 / 00)$ & 28 & 190 \\
$7(07 / 11 / 00-15 / 12 / 00)$ & 39 & 229 \\
$8(16 / 12 / 00-16 / 01 / 01)$ & 32 & 261 \\
$9(17 / 01 / 01-24 / 02 / 01)$ & 40 & 301 \\
$10(25 / 02 / 01-21 / 03 / 01)$ & 31 & 332 \\
$11(22 / 03 / 01-19 / 04 / 01)$ & 29 & 361 \\
$12(20 / 04 / 01-21 / 05 / 01)$ & 32 & 393 \\
$13(22 / 05 / 01-02 / 07 / 01)$ & 42 & 435 \\
$14(03 / 07 / 01-31 / 07 / 01)$ & 29 & 464 \\
$15(01 / 08 / 01-04 / 09 / 01)$ & 35 & 499 \\
$16(05 / 09 / 01-09 / 10 / 01)$ & 32 & 531 \\
$17(10 / 10 / 01-13 / 11 / 01)$ & 35 & 566 \\
$18(14 / 11 / 01-11 / 12 / 01)$ & 28 & 594 \\
$19(12 / 12 / 01-22 / 01 / 02)$ & 42 & 636 \\
$20(23 / 01 / 02-18 / 02 / 02)$ & 28 & 664 \\
\hline
\end{tabular}

A seguir serão discutidos os efeitos dos tratamentos sobre cada parâmetro de crescimento. 


\subsubsection{Altura}

Cabe ressaltar que a altura e diâmetro da haste principal são parâmetros amplamente usados nos estudos de palmeiras, pois são medidas de natureza não destrutiva, facilmente obtidas, especialmente nos estádios iniciais de crescimento e, via de regra, estão altamente correlacionados à produção de palmito (Clement \& Bovi, 2000). Assim, eles foram utilizados para verificação da resposta da planta no crescimento em altura aos tratamentos aplicados.

Um resumo da análise de variância realizada nos dados obtidos para todos os períodos avaliados estão apresentados na Tabela 16. Por esta tabela, é possível verificar que houve efeito significativo $(\mathrm{P}<0,05$ e $\mathrm{P}<0,01)$ dos tratamentos (irrigação e adubação), em grande parte dos períodos avaliados (em 15 períodos). Até 126 dias da imposição dos tratamentos não houve diferenças significativas em altura entre plantas. No entanto, a partir do quinto período (162 NDA), começaram a ocorrer diferenças estatísticas $(\mathrm{P}<0,01)$ conforme a altura das plantas, em função das doses de nitrogênio foram aplicadas, com exceção do período seis. Já, para lâminas de irrigação, houve diferença estatística $(\mathrm{P}<0,05$ e $\mathrm{P}<0,01)$ entre os tratamentos aplicados a partir do período 6 (190 NDA), mantendo-se até o período 20. Por sua vez, a interação lâmina x nitrogênio não mostrou efeito significativo $(\mathrm{P}>0,05$ e $\mathrm{P}<0,01)$ em nenhum dos períodos avaliados.

Em relação aos blocos, observa-se que houve efeito significativo $(\mathrm{P}<0,05$ e $\mathrm{P}<0,01$ ), principalmente, nos primeiros quatro períodos de avaliação, quando não houve efeito entre os tratamentos. Este efeito de bloco pode ter ocorrido como conseqüência da variabilidade genética e características da cultura, acarretando para o mesmo tratamento parcelas com plantas maiores em alguns blocos e menores em outros. Entretanto, a partir do momento em que começa a ocorrer efeito dos tratamentos sobre o crescimento das plantas, diminuiu o efeito dos blocos. Afinal, ao longo do tempo, observou-se no campo que com a aplicação dos tratamentos, há uma tendência em diminuir as diferenças iniciais entre as plantas nas parcelas. Isto também pode ser corroborado pela diminuição dos coeficientes de variação a partir deste mesmo período. Observe-se que, durante 
todos os períodos avaliados, de forma geral seus valores foram pequenos, variando de $10,71 \%$ a $16,57 \%$.

Tabela 16. Resumo da análise de variância para altura de planta nos períodos de avaliação.

\begin{tabular}{|c|c|c|c|c|c|c|c|}
\hline $\begin{array}{c}\text { Causas de } \\
\text { Variação } \\
\text { GL }\end{array}$ & $\begin{array}{c}\text { Lâmina } \\
3\end{array}$ & $\begin{array}{c}\text { Nitrogênio } \\
2\end{array}$ & $\begin{array}{c}\text { Interação } \\
\text { L x N } \\
6\end{array}$ & $\begin{array}{c}\text { Blocos } \\
3\end{array}$ & $\begin{array}{c}\text { Resíduo } \\
33\end{array}$ & $\begin{array}{l}\mathrm{CV} \\
(\%)\end{array}$ & $\begin{array}{c}\text { Média } \\
(\mathrm{cm})\end{array}$ \\
\hline Período & \multicolumn{7}{|c|}{ Quadrado Médio } \\
\hline 1 & 2,25 & 1,15 & 4,34 & $28,36^{*}$ & 6,66 & 16,57 & 15,58 \\
\hline 2 & 5,36 & 5,15 & 3,90 & $36,71 * *$ & 6,91 & 15,57 & 16,88 \\
\hline 3 & 7,09 & 11,10 & 4,85 & $43,52 * *$ & 7,96 & 15,08 & 17,86 \\
\hline 4 & 11,47 & 22,84 & 7,11 & $35,52 *$ & 10,28 & 15,97 & 20,07 \\
\hline 5 & 34,00 & $52,36^{* *}$ & 11,30 & 61,82 & 15,92 & 16,37 & 24,37 \\
\hline 6 & $106,75^{* *}$ & 66,21 & 18,51 & 61,50 & 23,10 & 16,58 & 28,99 \\
\hline 7 & $116,38 *$ & $100,07 *$ & 19,59 & $89,09 * *$ & 28,59 & 15,64 & 34,17 \\
\hline 8 & $153,47 *$ & $186,11 *$ & 23,22 & 76,71 & 41,11 & 15,42 & 41,58 \\
\hline 9 & $331,91 * *$ & $482,52 * *$ & 43,66 & 156,14 & 63,64 & 14,71 & 54,21 \\
\hline 10 & $512,55^{* *}$ & $944,11 * *$ & 41,85 & $213,63 * *$ & 72,38 & 13,56 & 62,73 \\
\hline 11 & $794,74 * *$ & $1536,59 * *$ & 39,66 & 238,03 & 91,08 & 13,41 & 71,15 \\
\hline 12 & $1043,15^{* *}$ & $1726,83 * *$ & 32,63 & 219,77 & 93,37 & 12,96 & 74,55 \\
\hline 13 & $1459,29 * *$ & $2008,83^{* *}$ & 25,67 & 350,70 & 122,92 & 13,79 & 80,39 \\
\hline 14 & $1747,83^{* *}$ & $2140,44 * *$ & 25,17 & $409,10^{* *}$ & 133,59 & 13,87 & 83,31 \\
\hline 15 & $2147,95 * *$ & $2149,67 * *$ & 26,73 & 279,40 & 133,37 & 13,19 & 87,51 \\
\hline 16 & $2459,21 * *$ & $2975,84 * *$ & 35,87 & 406,47 & 165,28 & 13,05 & 98,52 \\
\hline 17 & $2721,23 * *$ & $3568,29 * *$ & 57,89 & 403,91 & 178,28 & 12,25 & 108,97 \\
\hline 18 & $2787,53 * *$ & $3672,94 * *$ & 82,41 & 288,07 & 181,53 & 11,32 & 118,95 \\
\hline 19 & $2960,18 * *$ & $4534,64 * *$ & 126,02 & 287,23 & 209,05 & 10,72 & 134,86 \\
\hline 20 & $3010,47 * *$ & $5330,90 * *$ & 178,24 & 316,74 & 258,47 & 10,71 & 150,06 \\
\hline
\end{tabular}

* significativo ao nível de $5 \%$ pelo teste $\mathrm{F}$; ** significativo ao nível de $1 \%$ pelo teste $\mathrm{F}$

A Figura 15 representa a altura absoluta da planta, para as lâminas de irrigação e doses de nitrogênio, respectivamente, nos períodos avaliados. Por estas figuras, constatase que, no início, as diferenças em altura são pequenas entre os tratamentos. As plantas apresentavam altura média de 13,82 cm e verificou-se um menor crescimento nos quatro primeiros períodos de avaliação. A partir do quinto período, as plantas começaram a ter um crescimento em altura mais acentuado, principalmente, nos tratamentos L3 e L4 (Figura 15a) e N2 e N3 (Figura 15b). É possível perceber uma clara tendência em 
aumentar a diferença de crescimento entre plantas, a medida em que foram aplicados os tratamentos. A partir dos 361 NDA ( $11^{\circ}$ período), o crescimento foi menor até os 499 NDA ( $15^{\circ}$ período), pois conforme a Tabela 9 , neste intervalo, as menores temperaturas que ocorreram durante todo o período estudado, $18,67^{\circ} \mathrm{C}$ ( $13^{\circ}$ período) e $18,69^{\circ} \mathrm{C}\left(14^{\circ}\right.$ período), foram registradas. De outubro a fevereiro (do $16^{\circ}$ ao $20^{\circ}$ período), ocorreu um aumento da temperatura sendo este um período de crescimento intenso. Note-se que, no momento do corte, as plantas apresentavam altura média de 150,06 cm. Conforme a Tabela 16, até o último corte realizado, apenas 244 plantas do total avaliado já tinham alcançado a altura recomendada de corte $(1,60 \mathrm{~cm})$. Como foram cortadas todas as plantas úteis para avaliação dos tratamentos, a altura das plantas menores influenciou na média geral.

Os tratamentos com déficit hídrico ou sem irrigação (L1 e L2), apresentaram os menores crescimentos em altura durante todo o período avaliado (Figura 15a). O mesmo ocorreu para N1, conforme ilustra a Figura 15b.

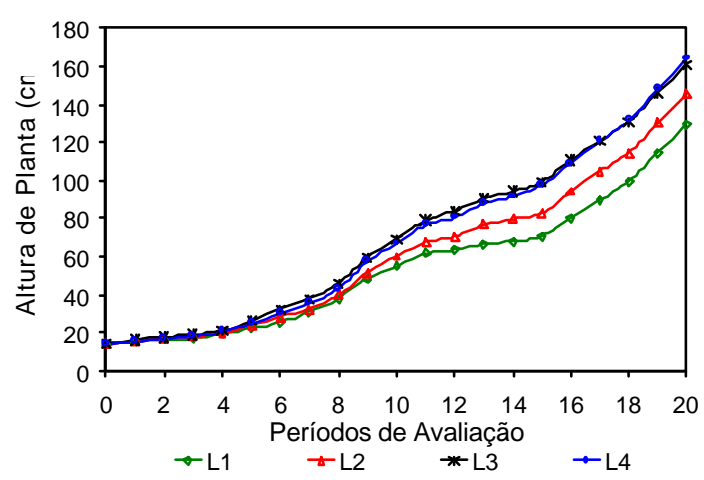

(a)

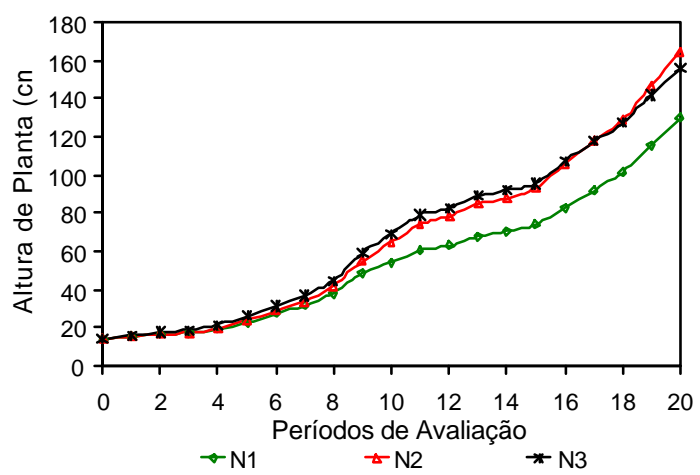

(b)

Figura 15 - Crescimento ( $\mathrm{cm}$ ) médio em altura em função das lâminas de irrigação (a) e das doses de nitrogênio (b).

As regressões entre os tratamentos e o parâmetro altura foram estabelecidas até o $19^{\circ}$ período. Cabe recordar que o último período não foi considerado, pois, não foram aplicadas as lâminas de irrigação devido às elevadas precipitações que ocorreram, sendo feitas somente fertirrigações. Os resultados apresentam-se na Tabela 17, onde se verifica 
que os tratamentos, lâminas e doses de nitrogênio, não tiveram efeitos sobre o crescimento em altura de planta até o quarto período de avaliação e que a interação lâmina x nitrogênio não foi significativa em nenhum período avaliado.

Tabela 17. Resumo da regressão linear e quadrática entre os tratamentos lâminas de irrigação e dosagens de adubação nitrogenada e o crescimento em altura.

\begin{tabular}{|c|c|c|c|c|c|}
\hline \multirow{3}{*}{$\begin{array}{l}\text { Causas de } \\
\text { Variação } \\
\text { Períodos }\end{array}$} & \multicolumn{2}{|c|}{ Lâmina } & \multicolumn{2}{|c|}{ Nitrogênio } & \multirow{3}{*}{$\begin{array}{c}\text { Interação } \\
\text { L x N }\end{array}$} \\
\hline & Linear & Quadrática & Linear & Quadrática & \\
\hline & \multicolumn{4}{|c|}{ Quadrado Médio } & \\
\hline 1 & 1,63 & 0,79 & 0,18 & 2,12 & 0,31 \\
\hline 2 & 7,32 & 4,44 & 5,67 & 4,62 & 0,22 \\
\hline 3 & 14,37 & 2,04 & 16,60 & 5,67 & 0,11 \\
\hline 4 & 25,77 & 2,95 & 33,86 & 11,82 & 0,23 \\
\hline 5 & $77,09 *$ & 8,82 & $102,57 *$ & 2,15 & 0,20 \\
\hline 6 & $271,68 * *$ & 13,55 & $128,48^{*}$ & 3,94 & 6,45 \\
\hline 7 & $268,15 * *$ & 2,93 & $195,71 *$ & 4,43 & 1,55 \\
\hline 8 & $358,55 * *$ & 4,13 & $368,01 * *$ & 4,21 & 4,62 \\
\hline 9 & $865,49 * *$ & 2,70 & $948,72 * *$ & 16,31 & 5,10 \\
\hline 10 & $1389,84 * *$ & 12,09 & $1768,29 * *$ & 119,93 & 11,93 \\
\hline 11 & $2183,23 * *$ & 10,28 & $2866,88^{* *}$ & 206,31 & 2,06 \\
\hline 12 & $2843,06^{* *}$ & 22,11 & $3144,53^{* *}$ & 309,13 & 2,13 \\
\hline 13 & $4099,21 * *$ & 56,20 & $3587,14 * *$ & 430,52 & 10,44 \\
\hline 14 & $4921,79 * *$ & 98,83 & $3807,47 * *$ & 473,43 & 13,35 \\
\hline 15 & $6158,44^{* *}$ & 43,75 & $3527,88^{* *}$ & $771,46^{*}$ & 6,11 \\
\hline 16 & $7095,97 * *$ & 93,81 & $4712,07 * *$ & $1239,61 * *$ & 59,17 \\
\hline 17 & $7960,18 * *$ & 90,33 & $5273,90 * *$ & $1862,68 * *$ & 119,29 \\
\hline 18 & $8199,27 * *$ & 74,00 & $5233,05 * *$ & $2112,84 * *$ & 138,92 \\
\hline 19 & $8769,99 * *$ & 58,07 & $5546,81 * *$ & $3522,47 * *$ & 156,89 \\
\hline
\end{tabular}

* significativo ao nível de $1 \%$ pelo teste $\mathrm{F}$; * significativo ao nível de $5 \%$ pelo teste $\mathrm{F}$

Em relação às lâminas de irrigação, verifica-se que a partir do quinto período, os efeitos lineares foram sempre significativos $(\mathrm{P}<0,05$ e $\mathrm{P}<0,01)$ e nenhum efeito quadrático significativo foi detectado. No $11^{\circ}$ período (Figura 16a), o efeito da irrigação sobre o crescimento em altura pode ser representado por $\mathrm{Y}=57,08+0,049 \mathrm{X}\left(\mathrm{R}^{2}=\right.$ 0,92\%). Para quantidades crescentes de lâminas de irrigação, a resposta de crescimento em altura foi também crescente até o último período avaliado, em resposta às lâminas totais de $144,00 \mathrm{~mm} /$ planta, $410,30 \mathrm{~mm} /$ planta, $678,1 \mathrm{~mm} /$ planta e $787,2 \mathrm{~mm} /$ planta 
aplicadas nos tratamentos L1, L2, L3 e L4, respectivamente. É pertinente lembrar que a pupunheira é natural de áreas com precipitações de $2000 \mathrm{~mm} \mathrm{ano}^{-1}$ e não só o total de precipitação é importante, como também sua distribuição. Períodos secos maiores que três meses ocasionam um atraso no desenvolvimento da planta, o que prejudicaria uma colheita precoce de palmito (Villachica, 1996). Ainda, Ramos et al., (2001) e Diotto et al., (1999) trabalhando com pupunheiras adultas determinaram um alto consumo hídrico pela cultura, sendo encontrados valores médios de coeficiente de cultura $(\mathrm{Kc})$ de 1,00 para a planta mãe e perfilhos. Resultados semelhantes foram obtidos por Lopes et al. (2000), comprovando o alto consumo hídrico da cultura.

Já, o nitrogênio começou a apresentar efeitos lineares significativos sobre o crescimento em altura, também, a partir do $5^{\circ}$ período (162 NDA). Até o $11^{\circ}$ período, em que se completa o parcelamento da adubação realizada por 12 meses, com a aplicação de $411 \mathrm{~kg}$ de $\mathrm{N} \mathrm{ha}^{-1} \mathrm{ano}^{-1}$ (para o tratamento $\mathrm{N} 3$ ) os efeitos lineares ainda foram significativos, com coeficiente de determinação $\mathrm{R}^{2}=0,93 \%$. Na medida em que se aumentavam as doses de nitrogênio aplicadas, ocorreram incrementos também crescentes na altura das plantas, sendo esta relação representada por $\mathrm{Y}=61,68+0,046 \mathrm{X}$, onde $\mathrm{X}$ é a dose de nitrogênio aplicada. Na ausência de adubação nitrogenada (N1) foram observados os menores valores de altura de planta (Figura 16b). Gusman (1985), em experimento realizado na Costa Rica com a pupunheira, avaliou a influência de quatro doses de nitrogênio sobre algumas características vegetativas. $\mathrm{O}$ autor constatou que o aumento de nitrogênio influenciava positivamente os parâmetros avaliados, até a dose de $367 \mathrm{~kg}$ de $\mathrm{N} \mathrm{ha}^{-1} \mathrm{ano}^{-1}$. Também, Bovi et al. (2002), estudando os efeitos de quatro doses de nitrogênio, fósforo e potássio, aplicados em cobertura, sobre alguns parâmetros de crescimento verificaram um máximo crescimento vegetativo com doses de $400 \mathrm{~kg}_{\mathrm{de}} \mathrm{N} \mathrm{ha}^{-1} \mathrm{ano}^{-1}$.

A partir do $15^{\circ}$ período, em que foram aplicados $321,09 \mathrm{~kg}_{\mathrm{de}} \mathrm{N} \mathrm{ha}^{-1}$ e $642,19 \mathrm{~kg}$ de $\mathrm{N} \mathrm{ha}^{-1}$ para $\mathrm{N} 2$ e N3, começam a ocorrer efeitos quadráticos, com efeitos crescentes sobre a altura de planta, somente até certa quantidade de nitrogênio aplicada, estendendo-se até o $19^{\circ}$ período. Embora estes efeitos quadráticos tenham sido significativos, a magnitude do efeito linear foi superior até o último período analisado. 
Por exemplo, para o $15^{\circ}$ período, $\operatorname{Pr}>\mathrm{F}=0,001$ e 0,0135 para linear e quadrático, respectivamente. Alguns autores têm comprovado que, por estar relacionado com a biomassa aérea e a produção, o nitrogênio é um elemento essencial para o desenvolvimento vegetativo de algumas palmeiras, como a pupunheira (Zamorra, 1985; Bovi et al., 2000; Bovi et al., 2002) e o coqueiro (Cocos nucifera L.) (Bonneau et al., 1993).

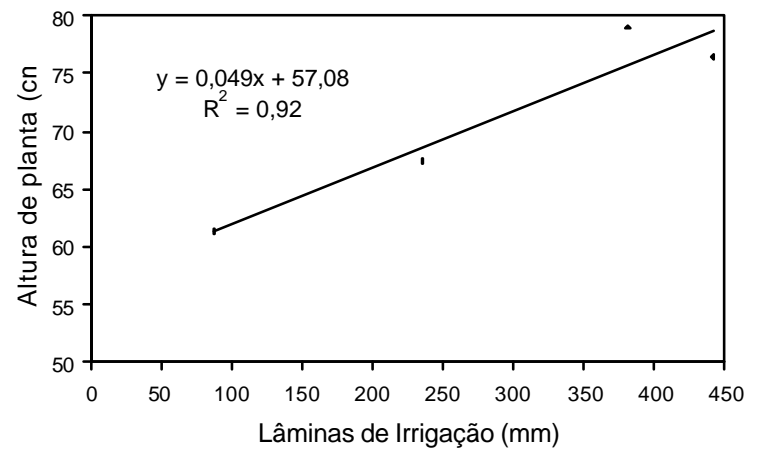

(a)

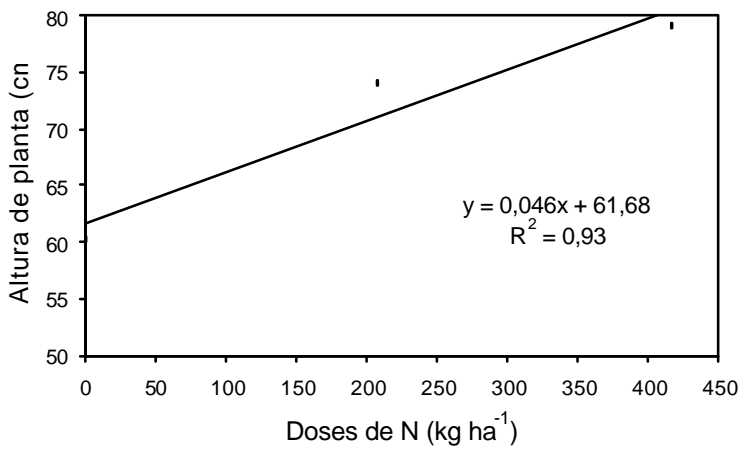

(b)

Figura 16 - Regressão linear: (a) entre as lâminas de irrigação acumuladas e crescimento em altura; (b) entre os níveis de nitrogênio acumulados e crescimento em altura, obtidas para o $11^{\circ}$ período.

\subsubsection{Diâmetro da planta}

O diâmetro da haste principal, assim como a altura, apresentaram correlações positivas e significativas para a produção de palmito (Bovi, et al., 1988, Clement et al., 1988). Como mencionado anteriormente, ambos os parâmetros são utilizados com freqüência para avaliar respostas das plantas aos tratamentos e mesmo para estimar o ponto de colheita.

Pela Tabela 18, é possível verificar que tanto para lâminas, quanto para nitrogênio, começam a ocorrer diferenças significativas $(\mathrm{P}<0,05$ e $\mathrm{P}<0,01)$ entre os tratamentos a partir do período 7, mantendo esta tendência até o período 20. Dessa forma, constata-se que a resposta da pupunheira aos tratamentos aplicados é mais lenta 
em diâmetro do que em altura, cuja resposta aos tratamentos ocorreu a partir do período 5. A interação lâmina $x$ nitrogênio não foi significativa $(P>0,05$ e $P<0,01)$ em nenhum dos períodos.

Tabela 18. Resumo da análise de variância para diâmetro de planta nos períodos de avaliação.

\begin{tabular}{|c|c|c|c|c|c|c|c|}
\hline $\begin{array}{c}\text { Causas } \\
\text { de } \\
\text { Variação } \\
\text { GL }\end{array}$ & Lâmina & Nitrogênio & $\begin{array}{c}\text { Interação } \\
\text { L x N } \\
6\end{array}$ & Blocos & $\begin{array}{c}\text { Resídu } \\
\text { o } \\
33\end{array}$ & $\mathrm{CV}$ & Média \\
\hline Período & \multicolumn{7}{|c|}{ Quadrado médio } \\
\hline 1 & 0,02 & 0,06 & 0,04 & 0,19 & 0,07 & 15,18 & 1,80 \\
\hline 2 & 0,07 & 0,13 & 0,08 & $0,57 * *$ & 0,11 & 15,50 & 2,17 \\
\hline 3 & 0,11 & 0,34 & 0,11 & $1,05^{* *}$ & 0,14 & 15,46 & 2,49 \\
\hline 4 & 0,19 & 0,46 & 0,13 & $0,98 * *$ & 0,17 & 15,25 & 2,77 \\
\hline 5 & 0,25 & 0,57 & 0,12 & $1,11 * *$ & 0,21 & 15,39 & 3,00 \\
\hline 6 & 0,55 & 0,76 & 0,20 & $0,98 *$ & 0,24 & 14,89 & 3,29 \\
\hline 7 & $0,88 *$ & $1,32 * *$ & 0,24 & $1,38 * *$ & 0,28 & 14,30 & 3,76 \\
\hline 8 & $1,16^{*}$ & $2,15 * *$ & 0,23 & 0,92 & 0,35 & 13,97 & 4,24 \\
\hline 9 & $2,92 * *$ & $4,38 * *$ & 0,27 & $1,45^{*}$ & 0,47 & 13,09 & 5,27 \\
\hline 10 & $3,86 * *$ & $6,13 * *$ & 0,36 & $1,67 *$ & 0,49 & 12,02 & 5,85 \\
\hline 11 & $4,91 * *$ & $7,53 * *$ & 0,30 & $2,38 *$ & 0,55 & 11,62 & 6,41 \\
\hline 12 & $5,55 * *$ & $7,98 * *$ & 0,21 & $1,65^{*}$ & 0,55 & 10,87 & 6,82 \\
\hline 13 & $7,87 * *$ & $7,88 * *$ & 0,35 & 1,24 & 0,65 & 10,63 & 7,61 \\
\hline 14 & $9,47 * *$ & $8,54 * *$ & 0,41 & 1,16 & 0,67 & 10,28 & 7,97 \\
\hline 15 & $10,53 * *$ & $6,45 * *$ & 0,56 & 0,60 & 0,71 & 10,01 & 8,44 \\
\hline 16 & $11,59 * *$ & $6,20 * *$ & 0,53 & 1,10 & 0,60 & 8,68 & 8,93 \\
\hline 17 & $11,29 * *$ & $6,50 * *$ & 0,54 & 0,63 & 0,54 & 7,87 & 9,31 \\
\hline 18 & $10,48 * *$ & $6,16 * *$ & 0,67 & 0,44 & 0,48 & 7,13 & 9,71 \\
\hline 19 & $10,32 * *$ & $6,06 * *$ & 0,57 & 1,28 & 0,47 & 6,78 & 10,21 \\
\hline 20 & $9,11 * *$ & $6,09 * *$ & 0,60 & 1,52 & 0,47 & 6,43 & 10,70 \\
\hline
\end{tabular}

* significativo ao nível de $5 \%$ pelo teste $\mathrm{F}$; ** significativo ao nível de $1 \%$ pelo teste $\mathrm{F}$

Assim como para altura, também houve efeito de blocos, entretanto, em relação ao diâmetro, esses efeitos foram significativos $(\mathrm{P}<0,05$ e $\mathrm{P}<0,01)$, em grande parte dos períodos avaliados, até o período 12. Para a altura, esses efeitos de bloco ocorreram em um número menor de períodos, pois, conforme observado, durante a condução do experimento, a planta apresenta maior resposta de crescimento em altura do que em diâmetro. A partir do período 13, não ocorreram mais efeitos significativos de blocos. 
Os coeficientes de variação para todas as avaliações realizadas ficaram entre $6,43 \%$ e $15,53 \%$. A partir do momento em que começaram as respostas das plantas aos tratamentos, tiveram seus valores reduzidos a cada avaliação realizada.

A Figura 17 representa o diâmetro da planta, nos diferentes tratamentos e períodos avaliados. Por esta figura, observa-se comportamento semelhante ao parâmetro altura, no que se refere à curva de crescimento obtida para os tratamentos L3 e L4 (Figura 17a) e N2 e N3 (Figura 17b), com exceção do período entre 361 NDA (11 período) e 499 NDA (15 período). Nestes intervalos, o crescimento em diâmetro aparentemente não sofreu influência da diminuição de temperatura ou de outros parâmetros climáticos. Como a magnitude do crescimento em diâmetro é menor do que em altura, este deve ser menos influenciado por condições adversas.

Os tratamentos que receberam as menores lâminas (L1 e L2) e dosagens de adubação nitrogenada (N1) também apresentaram um crescimento menor, quando comparados aos demais tratamentos.

Na primeira avaliação realizada, o diâmetro médio era de $1,45 \mathrm{~cm}$ e ao final, $10,70 \mathrm{~cm}$, sendo estas medidas realizadas a $10 \mathrm{~cm}$ do solo. Diâmetros acima de $9 \mathrm{~cm}$ são considerados por alguns autores (Mora Urpí et al., 1997) como indicativos de que a planta encontra-se em ponto de colheita de palmito

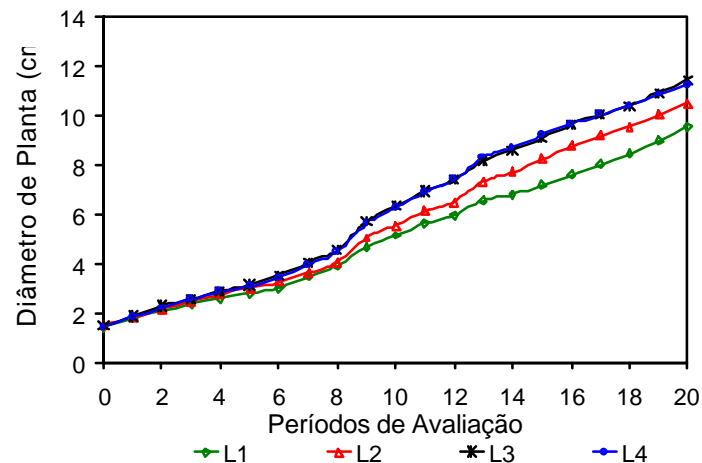

(a)

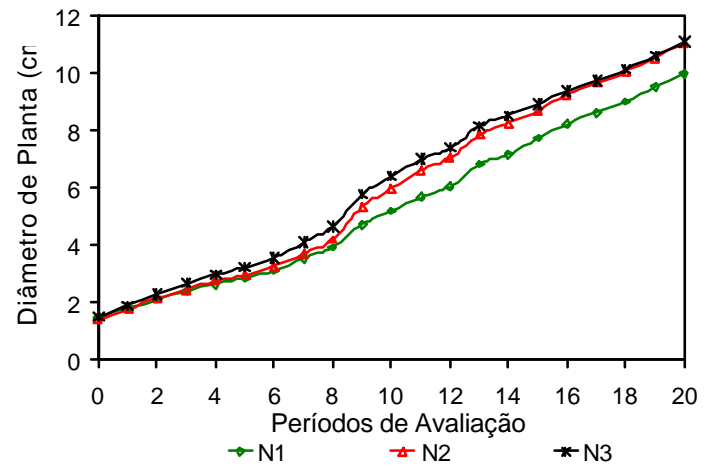

(b)

Figura 17 - Crescimento $(\mathrm{cm})$ médio diâmetro de planta em função das lâminas de irrigação (a) e das doses de nitrogênio (b). 
Os efeitos dos tratamentos sobre o crescimento em diâmetro da planta foram também semelhantes aos que ocorreram para altura. No entanto, para este parâmetro, a resposta ocorreu logo nos primeiros períodos de avaliação (Tabela 19). Para lâminas de irrigação, a partir do $6^{\circ}$ período, constatou-se efeito linear sobre diâmetro, ocorrendo um ajuste significativo $(\mathrm{P}<0,01)$ com coeficiente de determinação $\mathrm{R}^{2}=0,96 \%$ no $11^{\circ}$ período. $\mathrm{O}$ crescimento em diâmetro é expresso por $\mathrm{Y}=5,26+0,004 \mathrm{X}$ (Figura 20a). Estes efeitos lineares se mantiveram até o último período avaliado. Ramos et al. (2002) estudaram o desenvolvimento vegetativo de uma cultura de pupunheira, com três anos, em Terra Roxa Estruturada, em função de níveis de depleção de água no solo. Dentre as variáveis de crescimento testadas, encontraram maior crescimento em diâmetro de planta, altura e maior número de folhas novas emitidas para o tratamento com maior intensidade de aplicação de água (75\% AD). Alves Júnior et al. (2000) quantificaram e qualificaram os efeitos de lâminas de irrigação sobre as características vegetativas e produtivas de pupunheiras cultivadas no Noroeste Paulista e obtiveram um maior crescimento vegetativo e produtividade no tratamento que recebeu $75 \%$ da evapotranspiração do Tanque Classe A, no corte inicial, e 100\% ECA no segundo ano de produção.

Os efeitos lineares do nitrogênio começam a partir do $3^{\circ}$ período (96 NDA), perdurando até o último período avaliado (Tabela 19). Assim como para altura, no $11^{\circ}$ período, os efeitos da adubação nitrogenada sobre o crescimento em diâmetro são lineares, com $\mathrm{R}^{2}=0,95 \%$ e expresso por $\mathrm{Y}=5,74+0,032 \mathrm{X}$, onde $\mathrm{X}$ representa a dose de N aplicada (Figura 18b). Nos três últimos períodos, os efeitos são quadráticos. Entretanto, a magnitude do efeito linear é superior, possibilitando concluir que doses crescentes de $\mathrm{N}$ proporcionaram aumentos também crescentes no diâmetro da planta. Da mesma forma, Bovi et al. (2002), estudando os efeitos da adubação sobre o crescimento da pupunheira, concluíram que, ao longo de todo o período avaliado, doses crescentes de $\mathrm{N}$ proporcionaram aumentos também crescentes no diâmetro da haste principal. 
Tabela 19 - Resumo da regressão linear e quadrática entre os tratamentos lâminas de irrigação e dosagens de adubação nitrogenada e o crescimento em diâmetro.

\begin{tabular}{|c|c|c|c|c|c|}
\hline \multirow{3}{*}{$\begin{array}{l}\text { Causas de } \\
\text { Variação } \\
\text { Períodos }\end{array}$} & \multicolumn{2}{|c|}{ Lâmina } & \multicolumn{2}{|c|}{ Nitrogênio } & \multirow{3}{*}{$\begin{array}{c}\text { Interação } \\
\text { L x N }\end{array}$} \\
\hline & Linear & Quadrática & Linear & $\begin{array}{c}\text { Quadrátic } \\
\text { a }\end{array}$ & \\
\hline & \multicolumn{4}{|c|}{ Quadrado Médio } & \\
\hline 1 & 0,041 & 0,017 & 0,072 & 0,045 & 0,003 \\
\hline 2 & 0,129 & 0,038 & 0,232 & 0,033 & 0,038 \\
\hline 3 & 0,301 & 0,011 & $0,613 *$ & 0,054 & 0,020 \\
\hline 4 & 0,504 & 0,044 & $0,895^{*}$ & 0,036 & 0,045 \\
\hline 5 & 0,602 & 0,100 & $1,073 *$ & 0,065 & 0,038 \\
\hline 6 & $1,486^{*}$ & 0,0701 & $1,445^{*}$ & 0,073 & 0,028 \\
\hline 7 & $2,359 * *$ & 0,004 & $2,553^{*}$ & 0,102 & 0,040 \\
\hline 8 & $3,182 * *$ & 0,026 & $4,234 * *$ & 0,077 & 0,038 \\
\hline 9 & $8,209 * *$ & 0,006 & $8,673 * *$ & 0,097 & 0,050 \\
\hline 10 & $10,881 * *$ & 0,0001 & $11,821 * *$ & 0,453 & 0,094 \\
\hline 11 & $14,150 * *$ & 0,00008 & $14,164 * *$ & 0,899 & 0,252 \\
\hline 12 & $16,092 * *$ & 0,0003 & $14,521 * *$ & 1,441 & 0,186 \\
\hline 13 & $23,509 * *$ & 0,0329 & $14,391 * *$ & 1,387 & 1,075 \\
\hline 14 & $28,036 * *$ & 0,150 & $15,387 * *$ & 1,736 & 1,164 \\
\hline 15 & $31,196 * *$ & 0,322 & $11,328 * *$ & 1,545 & 1,848 \\
\hline 16 & $33,577 * *$ & 1,061 & $10,327 * *$ & 2,095 & 1,853 \\
\hline 17 & $32,432 * *$ & 1,697 & $10,626 * *$ & $2,375^{*}$ & 1,655 \\
\hline 18 & $30,345 * *$ & 0,961 & $9,929 * *$ & $2,385^{*}$ & 1,485 \\
\hline 19 & $29,481 * *$ & 1,154 & $10,023 * *$ & $2,092 *$ & 1,067 \\
\hline
\end{tabular}

* significativo ao nível de $5 \%$ pelo teste $\mathrm{F}$; ** significativo ao nível de $1 \%$ pelo teste $\mathrm{F}$

Do $17^{\circ}$ período ao $19^{\circ}$ período ocorreram efeitos quadráticos, mas, a significância da regressão linear foi maior $(\operatorname{Pr}>F=0,0001)$ do que para a quadrática $(\operatorname{Pr}$ $>\mathrm{F}=0,0332$ ). Esses dados levam a assumir que em todos os períodos ocorreram efeitos lineares crescentes com as doses de $\mathrm{N}$ aplicadas, onde os tratamentos que receberam os maiores níveis de adubação nitrogenada são os também de maior diâmetro das plantas.

A interação lâmina $\mathrm{x}$ nitrogênio não mostrou efeitos significativos em nenhum dos períodos avaliados (Tabela 19). 


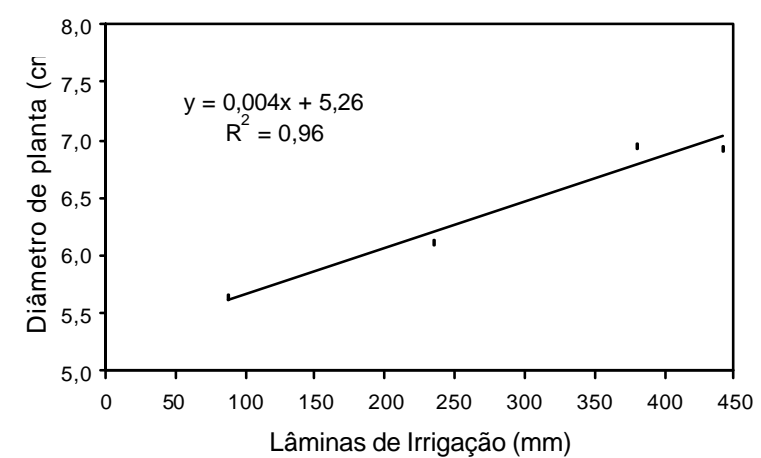

(a)

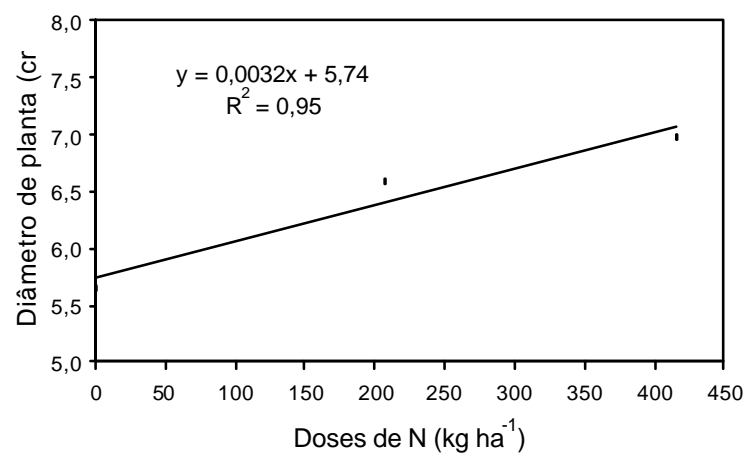

(b)

Figura 18 - Regressão linear: (a) entre as lâminas de irrigação acumuladas e crescimento em diâmetro; (b) entre os níveis de nitrogênio acumulados e crescimento em diâmetro, obtidas para o $11^{\circ}$ período.

\subsubsection{Número de folhas}

O número de folhas vivas, verdes ou funcionais está diretamente relacionado com o número de folhas internas e, portanto, com a produção de palmito. Esses número também reflete bem o efeito de estresse hídrico e adubação (Bovi, 1998; Bovi et al., 1988 ; Ramos et al., 2002).

Para o parâmetro número de folhas há efeito significativo $(\mathrm{P}<0,05$ e $\mathrm{P}<0,01)$ entre os tratamentos, principalmente, sob lâminas de irrigação do segundo período (64NDA) ao sétimo período (229 NDA). Posteriormente, somente ocorreram diferenças estatísticas, novamente, a partir do período 15 , até o $19^{\circ}$ período (Tabela 20).

Os períodos com efeitos significativos de lâminas (do $15^{\circ}$ período ao $19^{\circ}$ período) correspondem, principalmente, aos meses de agosto/2001 a janeiro/2002. Nesses meses, foram registrados altos valores de umidade relativa, temperatura e radiação (Tabela 9). Todos esses dados são um indicativo de que não só a irrigação influenciou na quantidade de folhas, mas também aqueles parâmetros climáticos. Isto é bem evidente na Figura 19, em que se constata um pico de crescimento em relação ao 
numero de folhas, chegando até, aproximadamente, 8,4 folhas planta $^{-1}$ do oitavo período ao nono período

Tabela 20. Resumo da análise de variância para número de folhas nos períodos de avaliação.

\begin{tabular}{|c|c|c|c|c|c|c|c|}
\hline $\begin{array}{c}\text { Causas de } \\
\text { Variação } \\
\text { GL }\end{array}$ & $\begin{array}{c}\text { Lâmina } \\
3\end{array}$ & $\begin{array}{c}\text { Nitrogênio } \\
2\end{array}$ & $\begin{array}{c}\text { Interação } \\
\text { L x N } \\
6\end{array}$ & $\begin{array}{c}\text { Blocos } \\
3\end{array}$ & $\begin{array}{c}\text { Resídu } \\
\text { o } \\
33\end{array}$ & $\mathrm{CV}$ & Média \\
\hline Período & \multicolumn{7}{|c|}{ Quadrado Médio } \\
\hline 1 & 0,663 & 0,100 & 0,123 & $1,374 * *$ & 0,283 & 7,93 & 6,70 \\
\hline 2 & $0,691 *$ & 0,398 & 0,528 & $0,675^{*}$ & 0,239 & 7,26 & 6,64 \\
\hline 3 & $1,125^{*}$ & $1,046 * *$ & 0,275 & $1,056 * *$ & 0,191 & 6,59 & 6,63 \\
\hline 4 & $1,233^{*}$ & 0,947 & 0,269 & 0,757 & 0,333 & 8,04 & 7,17 \\
\hline 5 & $1,499 * *$ & $1,484^{*}$ & 0,230 & 0,618 & 0,308 & 8,06 & 6,88 \\
\hline 6 & $1,543 * *$ & $1,083^{*}$ & 0,207 & 0,079 & 0,241 & 6,90 & 7,11 \\
\hline 7 & $1,181 * *$ & 0,517 & 0,183 & 0,405 & 0,204 & 5,74 & 7,85 \\
\hline 8 & 0,084 & 0,746 & 0,410 & 0,083 & 0,446 & 8,53 & 7,82 \\
\hline 9 & 0,548 & 0,267 & 0,066 & $0,833^{*}$ & 0,238 & 5,95 & 8,19 \\
\hline 10 & 0,574 & 0,273 & 0,163 & 0,355 & 0,249 & 6,68 & 7,46 \\
\hline 11 & 0,284 & 0,363 & 0,205 & 0,169 & 0,183 & 6,14 & 6,96 \\
\hline 12 & 0,414 & 0,737 & 0,307 & 0,286 & 0,256 & 7,82 & 6,47 \\
\hline 13 & 0,118 & 0,229 & 0,304 & 0,353 & 0,142 & 6,09 & 6,18 \\
\hline 14 & 0,530 & 0,101 & 0,244 & 0,261 & 0,175 & 7,20 & 5,82 \\
\hline 15 & $0,583^{*}$ & 0,147 & 0,254 & 0,169 & 0,142 & 6,79 & 5,55 \\
\hline 16 & $0,392 *$ & 0,109 & 0,232 & 0,284 & 0,141 & 6,57 & 5,71 \\
\hline 17 & $0,661 * *$ & 0,063 & 0,186 & 0,426 & 0,122 & 6,02 & 5,80 \\
\hline 18 & $0,548 *$ & 0,014 & 0,153 & $0,878 * *$ & 0,128 & 5,64 & 6,35 \\
\hline 19 & $0,261^{*}$ & 0,184 & 0,165 & $1,426 * *$ & 0,290 & 7,81 & 6,89 \\
\hline 20 & 0,197 & 0,040 & $0,823 *$ & 0,121 & 0,261 & 7,37 & 6,92 \\
\hline
\end{tabular}

* significativo ao nível de $5 \%$ pelo teste $\mathrm{F}$; ** significativo ao nível de $1 \%$ pelo teste $\mathrm{F}$

Observe-se que nestes períodos não houve efeito das lâminas aplicadas sobre o número médio de folhas e as temperaturas estiveram bem acima da média recomendada para a cultura, que é de $22^{\circ} \mathrm{C}$ (Tabela 9). Esses resultados estão em concordância com Diotto et al. (2001) que estudando a influência dos parâmetros climáticos sobre a taxa de crescimento das pupunheiras observaram que a época do ano exerceu influência na taxa de crescimento calculada em função da altura. Essa influência foi constatada tanto para os tratamentos com déficit, quanto para aqueles que não sofreram nenhuma deficiência 
hídrica, chegando a acarretar uma diminuição média de $60 \%$ na taxa de crescimento. No presente trabalho, tal fato pode ser atribuído à diminuição da quantidade de energia solar incidente, que ocorreu mais efetivamente durante os meses de maio a agosto.

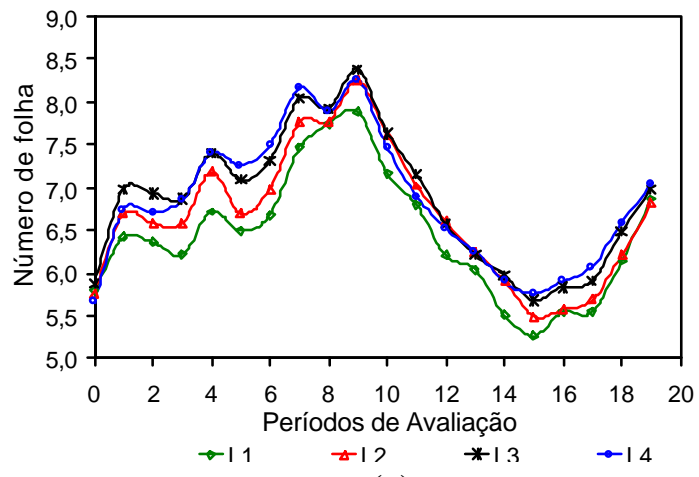

(a)

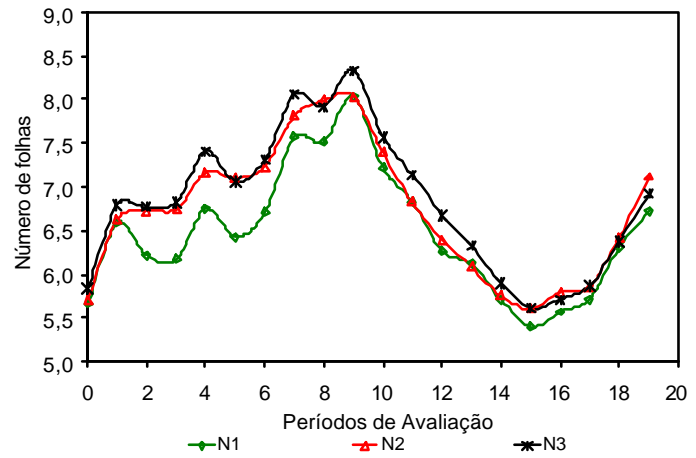

(b)

Figura 19 - Número médio de folhas em função das lâminas de irrigação (a) e das doses de nitrogênio (b).

Em relação às dosagens de nitrogênio, observa-se que os diferentes níveis aplicados influenciaram significativamente $(\mathrm{P}<0,05$ e $\mathrm{P}<0,01)$ o número de folhas somente nos períodos 3,5 e 6 . Nos demais períodos, não houve efeito significativo. Porém, é pertinente registrar, que no campo, as diferenças entre as tonalidades das folhas eram bem evidentes, dando a indicação de que este poderia ser um parâmetro de avaliação. Para a interação lâmina $\mathrm{x}$ nitrogênio, também, não houve diferença significativa entre os tratamentos $(\mathrm{P}>0,05$ e $\mathrm{P}<0,01)$.

Os coeficientes de variação (Tabela 21) foram bem pequenos $(5,64 \%$ a $8,53 \%)$, pois, o número de folhas foi relativamente uniforme, em todos os períodos avaliados. Contudo, apesar do número de folhas variar pouco, o parâmetrocomprimento da folha mostrou diferenças entre os tratamentos, conforme será visto adiante.

No início, as plantas apresentavam em média 5,78 folhas, chegando no período 10 até um valor de 8,4. Durante o desenvolvimento vegetativo da planta, como parte do processo fisiológico, a cada período, surgem novas folhas e ocorre a senescência e morte de folhas mais velhas, razão de uma certa flutuação em relação ao número de folhas 
entre os períodos. Mas, a partir do décimo período iniciou uma diminuição brusca do número de folhas (Figura 20), chegando a um valor médio de 5,3. Observando-se a Tabela 9, verifica-se que também ocorreu uma diminuição acentuada nos valores de temperatura média até o $14^{\circ}$ período, passando de $25,38^{\circ} \mathrm{C}$ (período 10) para $18,69^{\circ} \mathrm{C}$ (período 14). A diminuição acentuada da temperatura média nos períodos em discussão pode estar relacionada à redução no número de folhas. Do $15^{\circ}$ período em diante começa a aumentar o número de folhas novamente e, ao final,. as plantas apresentavam um número médio de 6,9 folhas.

Tabela 21. Resumo da regressão linear e quadrática entre os tratamentos lâminas de irrigação e dosagens de adubação nitrogenada e o número de folhas.

\begin{tabular}{cccccc}
\hline $\begin{array}{c}\text { Causas de } \\
\text { Variação }\end{array}$ & \multicolumn{2}{c}{ Lâmina } & \multicolumn{2}{c}{ Nitrogênio } \\
& Linear & Quadrática & Linear & Quadrátic & Interação \\
L x N \\
Períodos & \multicolumn{5}{c}{ Quadrado Médio } \\
\hline 1 & 1,326 & 0,330 & 0,058 & 0,142 & 0,136 \\
2 & $1,578^{*}$ & 0,188 & $2,057^{* *}$ & 0,127 & 0,872 \\
3 & $3,249^{* *}$ & 0,100 & $1,862^{* *}$ & 0,729 & 0,891 \\
4 & $3,409^{* *}$ & 0,288 & $1,886^{*}$ & 0,009 & 0,365 \\
5 & $4,393^{* *}$ & 0,097 & $2,194^{* *}$ & 0,774 & 0,196 \\
6 & $4,616^{* *}$ & 0,011 & $1,925^{* *}$ & 0,241 & 0,142 \\
7 & $3,542^{* *}$ & 0,0000014 & $0,931^{*}$ & 0,102 & 0,409 \\
8 & 0,204 & 0,0000091 & 0,901 & 0,591 & 0,025 \\
9 & $1,183^{*}$ & 0,426 & 0,396 & 0,139 & 0,011 \\
10 & 0,735 & 0,985 & 0,505 & 0,042 & 0,161 \\
11 & 0,209 & 0,430 & 0,591 & 0,135 & 0,235 \\
12 & 0,662 & 0,559 & $1,453^{*}$ & 0,022 & 0,595 \\
13 & 0,256 & 0,069 & 0,374 & 0,085 & 0,664 \\
14 & $1,108^{*}$ & 0,482 & 0,201 & 0,0011 & 0,101 \\
15 & $1,745^{* *}$ & 0,004 & 0,236 & 0,057 & 0,192 \\
16 & $1,062^{*}$ & 0,090 & 0,043 & 0,175 & 0,008 \\
17 & $1,906^{*}$ & 0,069 & 0,125 & 0,00007 & 0,452 \\
18 & $1,545^{* *}$ & 0,089 & 0,022 & 0,007 & 0,687 \\
19 & 0,676 & 0,574 & 0,087 & 0,281 & 0,021 \\
\hline
\end{tabular}

* significativo ao nível de $5 \%$ pelo teste $\mathrm{F}$; ** significativo ao nível de $1 \%$ pelo teste $\mathrm{F}$

Houve apenas efeitos lineares para lâminas e nitrogênio, sendo que nenhum efeito quadrático foi observado. Também não foi detectada a interação lâmina $x$ 
nitrogênio (Tabela 21) em nenhum período avaliado, seguindo a mesma tendência que para os outros parâmetros avaliados. Os efeitos lineares para o nitrogênio (Figura 21b), assim como para lâminas, começaram a ser significativos já a partir da segunda avaliação realizada, até o período 7 (229 NDA). A partir do $14^{\circ}$ período, começaram a ocorrer, novamente, efeitos lineares significativos sobre o parâmetro número de folhas.

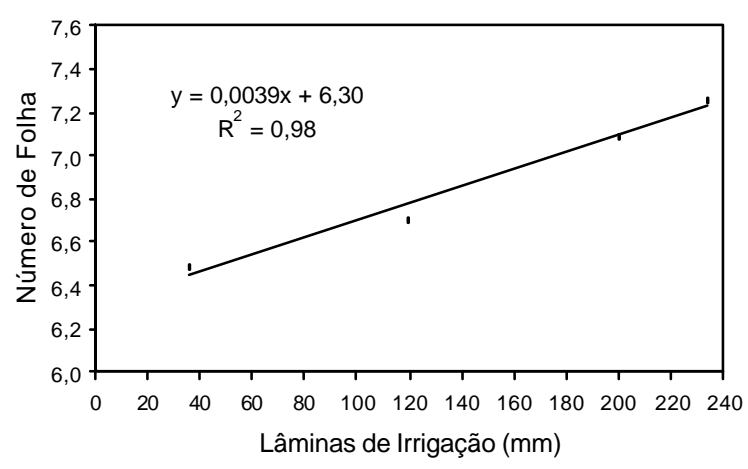

(a)

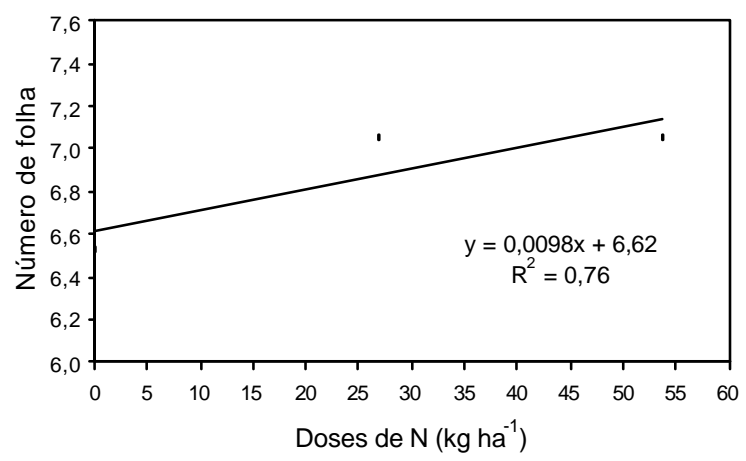

(b)

Figura 20 - Regressão linear: (a) entre as lâminas de irrigação acumuladas e o número de folhas; (b) entre os níveis de nitrogênio acumulados e o número de folhas, obtidas para o $5^{\circ}$ período.

Aos 162 NDA ( $5^{\circ}$ período), o efeito das lâminas sobre o número de folhas pode ser representado pela equação $\mathrm{Y}=6,30+0,0039 \mathrm{X}\left(\mathrm{R}^{2}=0,98 \%\right)$. O coeficiente de determinação obtido para a regressão entre as doses de $\mathrm{N}$ e o número de folhas foi menor $\left(R^{2}=0,76\right)$, podendo esta relação ser expressa por $Y=6,62+0,0098 X$.

\subsubsection{Folhas novas}

O número de folhas novas emitidas foi calculado entre duas avaliações consecutivas. O resumo da análise de variância encontra-se na Tabela 22 onde se verifica que houve efeito significativo $(\mathrm{P}<0,05$ e 0,01$)$ entre os tratamentos somente em

alguns períodos e, alternadamente, para lâminas e dosagens de nitrogênio. Assim como os demais parâmetros, para folhas novas a interação lâmina $\mathrm{x}$ nitrogênio não foi 
significativa ( $\mathrm{P}>0,05$ e $\mathrm{P}>0,01)$ em nenhum dos períodos avaliados. Esses resultados são concordante com Diotto et al. (2001) não encontraram diferença estatística para o número de folhas novas, em função das lâminas aplicadas. Nesse experimento, o número médio de folhas novas manteve-se sempre muito próximo em todos os tratamentos.

Também, houve efeito de blocos somente em alguns períodos, alternadamente, e os coeficientes de variação estiveram numa ampla faixa de $8,42 \%$ a 45,96\%. Nos primeiros períodos, seus valores eram maiores (de 35,27\% a 38,02\%) e foram diminuindo até o $4^{\circ}$ período. Já nos períodos 5 , do 12 ao 15 e 17 , ocorreram altos coeficientes de variação e pela Figura 21, constata-se que estes correspondem a períodos em que ocorreram um redução drástica no número de folhas novas emitidas.

Tabela 22. Resumo da análise de variância para folhas novas nos períodos de avaliação.

\begin{tabular}{cccccccc}
\hline $\begin{array}{c}\text { Causas de } \\
\text { Variação } \\
\text { GL }\end{array}$ & Lâmina & Nitrogênio & $\begin{array}{c}\text { Interação } \\
\text { L x N } \\
\text { Período }\end{array}$ & 3 & 2 & Blocos & Resíduo \\
Quadrado Médio & 3 & 33 & CV & Média \\
\hline 1 & $0,575^{* *}$ & 0,006 & 0,139 & $0,471^{*}$ & 0,124 & 37,39 & 0,94 \\
2 & 0,047 & $0,212^{* *}$ & 0,162 & $0,196^{* *}$ & 0,032 & 37,02 & 0,47 \\
3 & $0,093^{*}$ & 0,069 & 0,328 & 0,030 & 0,030 & 35,27 & 0,49 \\
4 & 0,016 & 0,0028 & 0,013 & 0,021 & 0,018 & 15,57 & 0,87 \\
5 & 0,013 & 0,042 & 0,013 & 0,031 & 0,028 & 25,68 & 0,66 \\
6 & $0,146^{* *}$ & 0,021 & 0,004 & $0,091^{* *}$ & 0,013 & 12,51 & 0,91 \\
7 & 0,0453 & 0,017 & 0,018 & $0,144^{* *}$ & 0,019 & 9,78 & 1,43 \\
8 & 0,016 & $0,075^{*}$ & 0,008 & 0,009 & 0,020 & 12,19 & 1,16 \\
9 & 0,011 & 0,098 & 0,051 & 0,075 & 0,043 & 13,10 & 1,57 \\
10 & 0,034 & $0,065^{*}$ & 0,021 & $0,093^{* *}$ & 0,019 & 14,96 & 0,93 \\
11 & 0,014 & $0,051^{*}$ & 0,011 & 0,007 & 0,011 & 13,37 & 0,81 \\
12 & $0,245^{* *}$ & 0,049 & 0,011 & 0,092 & 0,027 & 30,79 & 0,53 \\
13 & 0,022 & 0,051 & 0,016 & $0,198^{* *}$ & 0,023 & 25,05 & 0,61 \\
14 & $0,111^{*}$ & 0,003 & 0,043 & $0,098^{*}$ & 0,026 & 45,96 & 0,35 \\
15 & $0,081^{* *}$ & 0,037 & 0,067 & 0,014 & 0,017 & 21,42 & 0,62 \\
16 & 0,028 & 0,028 & 0,024 & $0,305^{* *}$ & 0,019 & 14,73 & 0,93 \\
17 & 0,057 & 0,060 & 0,026 & 0,187 & 0,020 & 21,68 & 0,65 \\
18 & $0,032^{*}$ & 0,017 & 0,008 & $0,072^{* *}$ & 0,007 & 8,42 & 1,03 \\
19 & 0,065 & 0,017 & 0,017 & $1,151^{* *}$ & 0,049 & 13,56 & 1,64 \\
20 & $0,172^{*}$ & $0,518^{* *}$ & 0,026 & 0,065 & 0,047 & 13,20 & 1,64 \\
\hline
\end{tabular}

* significativo ao nível de $5 \%$ pelo teste $\mathrm{F}$; ** significativo ao nível de $1 \%$ pelo teste $\mathrm{F}$ 


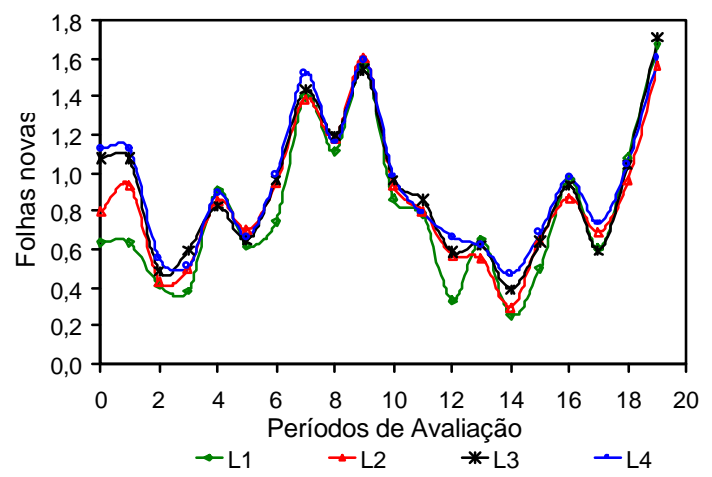

(a)

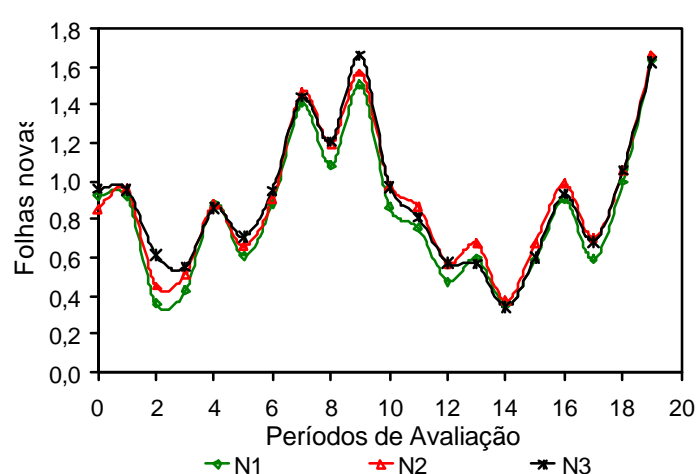

(b)

Figura 21 - Emissão de folhas novas em função das lâminas de irrigação (a) das doses de nitrogênio (b).

Como o número médio de folhas está diretamente relacionado à emissão de folhas novas, o comportamento de crescimento foi bem semelhante a ambos, com uma maior emissão de folhas novas nos períodos de 4 a 9 (126 a 301 NDA) e 15 a 20 (499 NDA a 664 NDA). Estes períodos coincidem com os meses de temperaturas mais elevadas, com possível influência de alguns parâmetros climáticos, além dos tratamentos aplicados, no crescimento das plantas e conforme discutido anteriormente. Isto pode ser observado na Figura 22a e 22b, onde os valores médios de folhas novas emitidas variaram de 0,47 folha a 1,64 folha por período. Ademais, as maiores médias foram obtidas nos períodos que compreendem os meses de setembro/2000 a fevereiro/2001 (períodos de 5 a 10). O mesmo comportamento repetiu-se nos mesmos meses do ano seguinte (períodos 16 a 20), mas com menores valores de coeficientes de variação $(8,42 \%$ a 25,68\%). Para este parâmetro, a sazonalidade dos valores de emissão de folhas, juntamente com a variação dos parâmetros climáticos, é ainda mais visível, particularmente, quando comparado ao número de folhas, conforme ilustrado na Figura 22.

Ainda, a regressão linear entre o número de emissão de folhas com o nitrogênio foi significativa em poucos períodos e com uma alternância entre os mesmos (Tabela 23). No $2^{\circ}$ período, a equação que pode representar o efeito linear do nitrogênio, sobre o número de folhas novas emitidas é $\mathrm{Y}=0,34+0,0095 \mathrm{X}$. e o coeficiente de determinação 
obtido foi de $\mathrm{R}^{2}=0,98 \%$. Pela Figura $22 \mathrm{~b}$, verifica-se que o maior número de folhas novas emitidas ocorreu no tratamento N2 (200 kg ha ${ }^{-1}$ ano $^{-1}$ ), seguido por N3 (400 kg ha${ }^{1}$ ano $\left.^{-1}\right)$.

Tabela 23. Resumo da regressão linear e quadrática entre os tratamentos lâminas de irrigação e dosagens de adubação nitrogenada e emissão de folhas novas.

\begin{tabular}{|c|c|c|c|c|c|}
\hline \multirow{3}{*}{$\begin{array}{l}\text { Causas de } \\
\text { Variação } \\
\text { Períodos }\end{array}$} & \multicolumn{2}{|c|}{ Lâmina } & \multicolumn{2}{|c|}{ Nitrogênio } & \multirow{2}{*}{$\begin{array}{c}\text { Interação } \\
\text { L x N }\end{array}$} \\
\hline & Linear & Quadrática & Linear & Quadrátic & \\
\hline & \multicolumn{5}{|c|}{ Quadrado Médio } \\
\hline 1 & $1,66 * *$ & 0,0701 & 0,0091 & 0,0028 & 0,0009 \\
\hline 2 & 0,1242 & 0,0143 & $0,5248 * *$ & 0,0128 & 0,4243 \\
\hline 3 & $0,1849^{*}$ & 0,0595 & $0,1288^{*}$ & 0,0102 & 0,0348 \\
\hline 4 & 0,0091 & 0,0380 & 0,0052 & 0,0004 & 0,0086 \\
\hline 5 & 0,0058 & 0,0198 & 0,0840 & 0,000004 & 0,0566 \\
\hline 6 & $0,3587 * *$ & 0,0722 & 0,0406 & 0,0008 & 0,0028 \\
\hline 7 & 0,0851 & 0,0440 & 0,0091 & 0,0247 & 0,0063 \\
\hline 8 & 0,0242 & 0,02161 & $0,1237^{*}$ & 0,0270 & 0,0014 \\
\hline 9 & 0,0002 & 0,0017 & 0,1953 & 0,0018 & 0,0033 \\
\hline 10 & $0,0974 *$ & 0,0046 & $0,0871 *$ & 0,0446 & 0,0315 \\
\hline 11 & 0,0068 & 0,0064 & 0,0253 & $0,0759^{*}$ & 0,0309 \\
\hline 12 & $0,6358 * *$ & 0,0538 & 0,0770 & 0,0225 & 0,0005 \\
\hline 13 & 0,0013 & 0,0449 & 0,0066 & 0,0950 & 0,0046 \\
\hline 14 & $0,3108 * *$ & 0,0221 & 0,0004 & 0,0056 & 0,0014 \\
\hline 15 & $0,1978 * *$ & 0,0255 & 0,0010 & 0,0737 & 0,0045 \\
\hline 16 & 0,0022 & 0,0806 & 0,0058 & 0,0518 & 0,0008 \\
\hline 17 & 0,0281 & 0,00001 & 0,0712 & 0,0499 & 0,0029 \\
\hline 18 & 0,0006 & $0,0770 * *$ & 0,0270 & 0,0071 & 0,0098 \\
\hline 19 & 0,000007 & 0,095 & 0,0010 & 0,0337 & 0,0033 \\
\hline
\end{tabular}

* significativo ao nível de $5 \%$ pelo teste $\mathrm{F}$; ** significativo ao nível de $1 \%$ pelo teste $\mathrm{F}$

Em relação às lâminas, os efeitos lineares foram significativos por um maior número de períodos. $\mathrm{O}$ gráfico da regressão para lâminas foi estabelecido para $\mathrm{o} 10^{\circ}$ período, pois, devido à alternância de significância entre os períodos, este representa o de máximo crescimento para esta variável. A equação que expressa o efeito da lâmina sobre a variável é Y $=0,84+0,0004 X$ (Figura 22a). Observe-se que a lâmina L4 foi a que proporcionou uma maior emissão de folhas. Ainda, para lâminas foi obtido um maior efeito linear $\left(R^{2}=0,95 \%\right)$ do que para nitrogênio $\left(R^{2}=0,66 \%\right)$. 
Tanto para lâminas, quanto para nitrogênio, apenas em um período (período 18) a regressão quadrática foi significativa (Tabela 23).

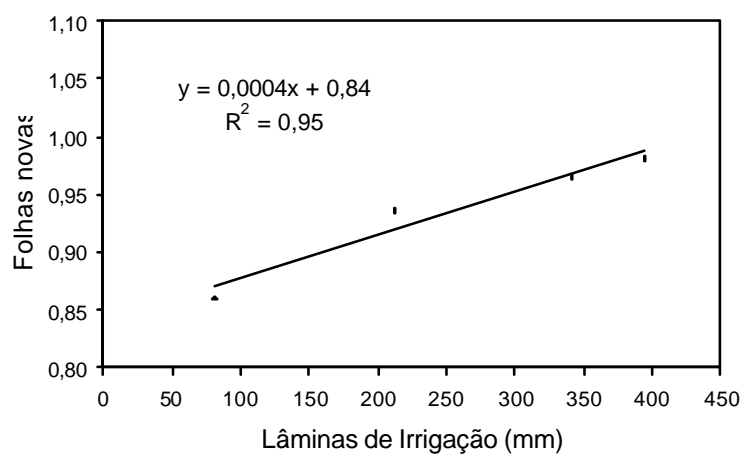

(a)

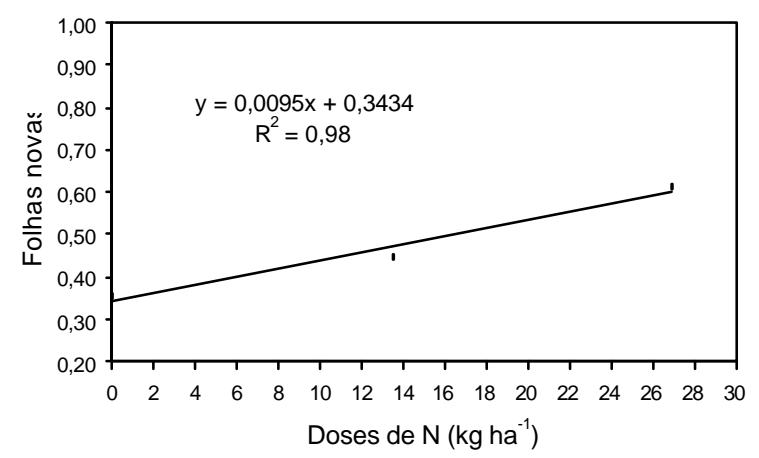

(b)

Figura 22 - Regressão linear: (a) entre as lâminas de irrigação acumuladas e o número de folhas novas, obtida para o $10^{\circ}$ período; (b) entre os níveis de nitrogênio acumulados e a emissão de folhas novas, obtida para o $2^{\circ}$ período.

\subsubsection{Comprimento da folha}

Cabe recordar que o comprimento e largura da folha são medidas lineares amplamente usadas em palmeiras (Bovi et al., 1992; Clement, 1995). Também, ambos apresentam correlações significativas com a produção de palmito (Bovi, et al., 1998, Clement et al., 1988), uma vez que esse produto é constituído, basicamente, pelo meristema apical e um número variável de folhas internas, ainda não plenamente desenvolvidas (Bovi, 1998).

As medidas de comprimento de folha somente começaram a ser efetuadas a partir do período 8 (261NDA), conforme se observa na Tabela 24.Tal procedimento foi adotado em virtude da constatação no campo que o número de folhas era relativamente uniforme entre os tratamentos. A despeito disso, notou-se que havia variações evidentes no comprimento da ráquis foliar, bem como no número, dimensões e coloração dos folíolos. Os resultados da análise estatística confirmaram essa observação prática. Dessa forma, verificou-se também, que ocorreram diferenças significativas $(\mathrm{P}<0,05$ e $\mathrm{P}<0,01)$ 
entre as lâminas de irrigação do $8^{\circ}$ período (261NDA) ao $19^{\circ}$ (636 NDA) período. Apesar disso, para número de folhas entre o $8^{\circ}$ período e o $13^{\circ}$ (435 NDA período não houve diferenças estatísticas entre as lâminas aplicadas. Estudos têm mostrado que a largura e o comprimento da folha podem ser influenciados por fatores ambientais sazonais, como por exemplo, as precipitações (Clement \& Urpí, 1983). Neste experimento, conclui-se que, de fato, o comprimento da folha foi mais influenciado pelos tratamentos (principalmente, as lâminas) do que o parâmetro número de folhas.

Tabela 24. Resumo da análise de variância para comprimento de folha, nos períodos de avaliação.

\begin{tabular}{cccccccc}
\hline $\begin{array}{c}\text { Causas de } \\
\text { Variação }\end{array}$ & Lâmina & Nitrogênio & $\begin{array}{c}\text { Interação } \\
\text { L x N } \\
\text { GL }\end{array}$ & 3 & 2 & $\begin{array}{c}\text { Blocos } \\
\text { Período }\end{array}$ & \multicolumn{7}{c}{$\begin{array}{c}\text { Resíduo } \\
\text { Quadrado Médio }\end{array}$} & 3 & 33 & CV & Média \\
\hline 8 & 123,13 & 28,14 & 43,09 & $269,85^{* *}$ & 48,26 & 21,78 & 31,89 \\
9 & $229,13^{*}$ & 16,52 & 58,21 & 191,02 & 66,12 & 20,66 & 39,35 \\
10 & $389,16^{*}$ & 45,39 & 67,14 & $439,27 * *$ & 98,35 & 19,50 & 50,83 \\
11 & $602,40^{* *}$ & 96,64 & 86,61 & $425,46^{*}$ & 136,14 & 19,35 & 60,27 \\
12 & $806,18^{* *}$ & 168,77 & 125,02 & 329,13 & 164,05 & 18,36 & 69,73 \\
13 & $1313,88^{* *}$ & 280,02 & 213,15 & $542,38^{*}$ & 185,84 & 17,85 & 76,33 \\
14 & $1599,33^{* *}$ & 361,02 & 190,44 & 509,16 & 187,65 & 16,17 & 84,66 \\
15 & $1859,94 * *$ & 507,25 & 205,94 & 519,05 & 196,38 & 15,65 & 89,50 \\
16 & $2455,33^{* *}$ & $681,02^{*}$ & 280,60 & 482,33 & 203,94 & 14,47 & 98,67 \\
17 & $2857,91 * *$ & $842,27 *$ & 254,27 & 596,52 & 217,95 & 13,67 & 107,96 \\
18 & $2966,68^{* *}$ & $1033,52^{*}$ & 239,35 & 560,24 & 242,18 & 13,36 & 116,48 \\
19 & $3038,47 * *$ & $1120,68^{*}$ & 255,15 & 141,19 & 230,54 & 11,78 & 128,88 \\
20 & $2942,88^{* *}$ & $1350,14 * *$ & 275,28 & 30,83 & 231,95 & 10,76 & 141,42 \\
\hline
\end{tabular}

* significativo ao nível de 5\% pelo teste $\mathrm{F}$; * significativo ao nível de $1 \%$ pelo teste $\mathrm{F}$

Inicialmente, as plantas apresentavam um comprimento médio de folhas de 31,89 $\mathrm{cm}$, aumentando nos períodos subseqüentes até atingir um comprimento de 141,42 cm aos 636 NDA, conforme se observa na Figura 23. Em dendezeiro (Elaeis guineensis) foi reportado que o tamanho da folha aumenta durante o estádio juvenil, até atingir a maturidade. A seguir, estabiliza-se por um período de tempo e, então, começa a diminuir suavemente (Hardon, et al., 1969; Corley \& Grey, 1976 citados por Clement \& Urpí, 
1983). Para que todo esse comportamento fosse observado em pupunheira seria necessário esperar que a planta atingisse a fase reprodutiva, que é alcançada após o sexto ano de campo (Mora-Urpi et al., 1997).

Em relação ao nitrogênio, só começaram a ocorrer diferenças significativas $(\mathrm{P}<0,05$ e $\mathrm{P}<0,01)$ entre as dosagens, a partir do $16^{\circ}$ período (531NDA). O coeficiente de variação no período 8 foi de $21,78 \%$ e seus valores foram diminuindo nos demais períodos até atingir um valor de $10,76 \%$, no último período avaliado. Existe a possibilidade dessa diminuição nos valores do coeficiente de variação ter ocorrido em função dos tratamentos aplicados, que com o tempo, podem ter diminuído as desuniformidades iniciais entre plantas, que é característica da própria cultura.

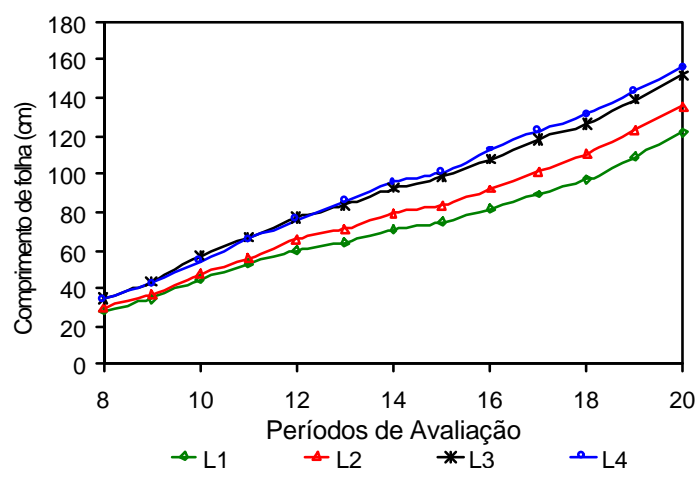

(a)

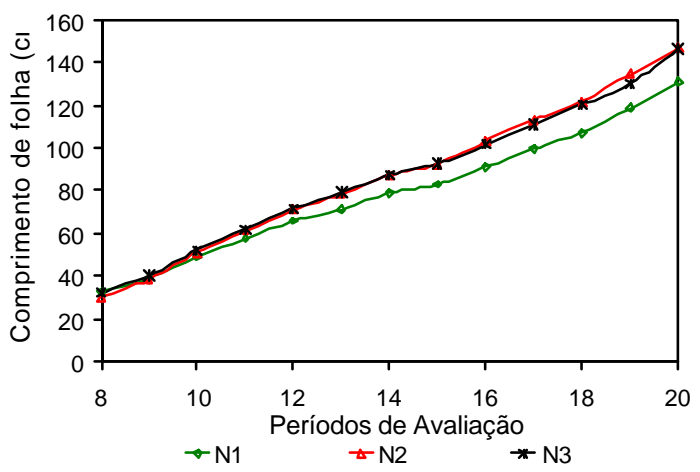

(b)

Figura 23 - Comprimento da folha em função das lâminas de irrigação (a) e doses de nitrogênio (b).

Pela Tabela 25, verifica-se que houve apenas efeitos lineares para lâminas e nitrogênio, sem efeitos quadráticos e nem interação $\mathrm{L} \times \mathrm{N}$ significativa entre estes tratamentos. Efeitos lineares das lâminas foram detectados em todos os períodos avaliados, com aumentos crescentes no comprimento de folha a medida em que se aumenta a lâmina de irrigação aplicada. Esta relação expressa por $\mathrm{Y}=73,49+0,0563 \mathrm{X}$ $(\mathrm{R} 2=0,99 \%)$ para $\mathrm{o} 16^{\circ}$ período (Figura 24a). Para nitrogênio, os efeitos lineares começam a ocorrer a partir do $15^{\circ}$ período e foram o último. Enquanto que para lâminas, a regressão foi linear já a partir do oitavo período, sendo que este é o primeiro período 
Tabela 25. Resumo da regressão linear e quadrática entre os tratamentos lâminas de irrigação e dosagens de adubação nitrogenada e o comprimento de folha.

\begin{tabular}{|c|c|c|c|c|c|}
\hline \multirow{3}{*}{$\begin{array}{l}\text { Causas de } \\
\text { Variação } \\
\text { Períodos }\end{array}$} & \multicolumn{2}{|c|}{ Lâmina } & \multicolumn{2}{|c|}{ Nitrogênio } & \multirow{3}{*}{$\begin{array}{c}\text { Interação } \\
\text { L x N }\end{array}$} \\
\hline & Linear & Quadrática & Linear & $\begin{array}{c}\text { Quadrátic } \\
\text { a }\end{array}$ & \\
\hline & \multicolumn{4}{|c|}{ Quadrado Médio } & \\
\hline 8 & $347,84 * *$ & 0,43 & 0,78 & 55,51 & 57,20 \\
\hline 9 & $638,44 * *$ & 1,84 & 18,00 & 15,04 & 64,74 \\
\hline 10 & $958,19 * *$ & 0,18 & 87,77 & 3,01 & 60,97 \\
\hline 11 & $1650,26 * *$ & 12,43 & 175,78 & 17,51 & 157,44 \\
\hline 12 & $2285,36^{* *}$ & 0,59 & 281,90 & 55,63 & 203,65 \\
\hline 13 & $3877,11^{* *}$ & 15,49 & 488,28 & 71,76 & 307,22 \\
\hline 14 & $4768,57 * *$ & 13,36 & 569,53 & 152,51 & 281,43 \\
\hline 15 & $5507,68 * *$ & 9,46 & $780,12 *$ & 234,37 & 371,81 \\
\hline 16 & $7317,76^{* *}$ & 32,09 & $871,42 *$ & 490,62 & 457,02 \\
\hline 17 & $8545,89 * *$ & 3,59 & $1035,35 *$ & 661,71 & 349,68 \\
\hline 18 & $8888,12^{* *}$ & 0,79 & $1350,99 *$ & 716,04 & 252,62 \\
\hline 19 & $9102,67 * *$ & 0,41 & $1498,68 *$ & 742,68 & 134,26 \\
\hline
\end{tabular}

* significativo ao nível de $1 \%$ pelo teste $\mathrm{F}$; ${ }^{*}$ significativo ao nível de $5 \%$ pelo teste $\mathrm{F}$

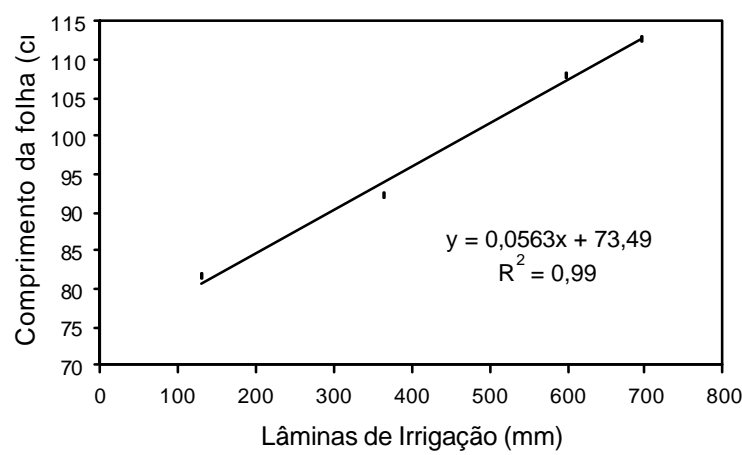

(a)

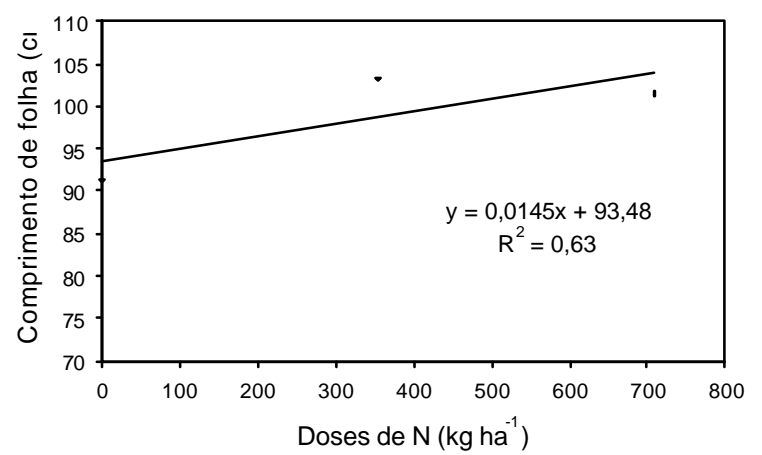

(b)

Figura 24 - Regressão linear: (a) entre as lâminas de irrigação acumuladas e o comprimento de folha; (b) entre os níveis de nitrogênio acumulados e comprimento de folha, obtidas para o $16^{\circ}$ período.

em que se começou a avaliar este parâmetro. Além disso, no mesmo período, o coeficiente de determinação obtido para as lâminas, foi superior ao nitrogênio $(\mathrm{R} 2=$ 
0,63\%). Caso tivesse sido avaliado anteriormente, talvez, esse efeito linear fosse observado já nos primeiros períodos, como aconteceu com o número de folhas.

\subsubsection{Número de perfilhos}

Conforme citado anteriormente, o número de perfilhos é uma característica fundamental, pois, avalia a capacidade de regeneração da planta e é muito afetado pela densidade do plantio. Trata-se, portanto, de um importante parâmetro fisiológico de estudo em pupunheiras (Clement \& Bovi, 2000).

Pela Tabela 26, é possível constatar que as lâminas de irrigação não influenciaram no parâmetro número de perfilhos em nenhum dos períodos avaliados. Já, para nitrogênio, ocorreram diferenças significativas entre as dosagens a partir do $8^{\circ}$ período (261NDA), mantendo-se assim até o $20^{\circ}$ período (664NDA), como ocorreu para os parâmetros altura e diâmetro do caule. Bovi et al. (2002), também, encontraram resposta significativa sobre os efeitos do nitrogênio no perfilhamento com o emprego de adubação convencional. Segundo esses autores, os efeitos começaram a ser estatisticamente significativos seis meses após o início da aplicação das adubações, quando as plantas estavam com 12 meses a campo. Esta resposta tardia, em relação ao nitrogênio pode ser consequiência de um efeito acumulativo do nitrogênio no solo, depois dos primeiros meses de aplicação dos tratamentos. Exatamente como aconteceu para os parâmetros altura e diâmetro de planta, em que os níveis de nitrogênio aplicados somente começaram a influenciar no crescimento a partir do $5^{\circ}$ período e $7^{\circ}$ período, respectivamente. 
Tabela 26. Resumo da análise de variância para número de perfilhos, nos períodos de avaliação.

\begin{tabular}{|c|c|c|c|c|c|c|c|}
\hline $\begin{array}{c}\text { Causas de } \\
\text { Variação } \\
\text { GL }\end{array}$ & $\begin{array}{c}\text { Lâmina } \\
3\end{array}$ & $\begin{array}{c}\text { Nitrogênio } \\
2\end{array}$ & $\begin{array}{c}\text { Interação } \\
\text { L x N } \\
6\end{array}$ & $\begin{array}{c}\text { Blocos } \\
3\end{array}$ & $\begin{array}{c}\text { Resíduo } \\
33\end{array}$ & $\mathrm{CV}$ & Média \\
\hline Período & \multicolumn{7}{|c|}{ Quadrado Médio } \\
\hline 1 & 0,058 & 0,037 & 0,060 & $1,392 * *$ & 0,190 & 70,32 & 0,62 \\
\hline 2 & 0,156 & 0,105 & 0,197 & $1,817 * *$ & 0,276 & 61,80 & 0,84 \\
\hline 3 & 0,278 & 0,148 & 0,318 & $2,953^{* *}$ & 0,356 & 57,63 & 1,04 \\
\hline 4 & 0,361 & 0,274 & 0,416 & $2,931 * *$ & 0,423 & 48,19 & 1,34 \\
\hline 5 & 0,237 & 0,341 & 0,383 & $3,277 * *$ & 0,511 & 39,82 & 1,79 \\
\hline 6 & 0,873 & 1,438 & 0,425 & $3,034^{* *}$ & 0,560 & 31,07 & 2,41 \\
\hline 7 & 0,692 & $3,732 * *$ & 0,241 & $3,275^{* *}$ & 0,685 & 22,95 & 3,61 \\
\hline 8 & 0,836 & $4,879 * *$ & 0,590 & $2,11^{*}$ & 0,647 & 18,89 & 4,26 \\
\hline 9 & 1,543 & $5,689 * *$ & 0,214 & $4,309^{* *}$ & 0,691 & 15,06 & 5,51 \\
\hline 10 & 1,151 & $8,313 * *$ & 0,483 & $3,918^{* *}$ & 0,735 & 14,09 & 6,08 \\
\hline 11 & 2,196 & $11,275^{* *}$ & 0,498 & $3,086^{*}$ & 0,980 & 14,76 & 6,71 \\
\hline 12 & 2,064 & $10,688^{* *}$ & 0,553 & 2,452 & 0,915 & 13,84 & 6,91 \\
\hline 13 & 1,777 & $8,586 * *$ & 0,635 & 1,575 & 1,070 & 13,79 & 7,49 \\
\hline 14 & 1,748 & $9,531 * *$ & 0,634 & 1,715 & 1,086 & 13,54 & 7,69 \\
\hline 15 & 1,652 & $8,862 * *$ & 0,776 & 1,432 & 0,882 & 11,70 & 8,03 \\
\hline 16 & 1,690 & $9,664 * *$ & 0,778 & 2,867 & 0,925 & 11,81 & 8,14 \\
\hline 17 & 1,256 & $8,817 * *$ & 0,813 & 1,279 & 1,302 & 13,24 & 8,62 \\
\hline 18 & 1,319 & $8,225^{* *}$ & 0,802 & 0,844 & 1,193 & 12,20 & 8,94 \\
\hline 19 & 1,793 & $5,749^{*}$ & 1,018 & 0,623 & 1,202 & 11,42 & 9,59 \\
\hline 20 & 1,671 & $11,935^{*}$ & 6,587 & 2,233 & 1,219 & 11,45 & 9,64 \\
\hline
\end{tabular}

* significativo ao nível de 5\% pelo teste $\mathrm{F}$; ** significativo ao nível de $5 \%$ pelo teste $\mathrm{F}$

Os coeficientes de variação obtidos para as avaliações realizadas até o $6^{\circ}$ período foram muito altos (de $31,07 \%$ a $74,52 \%$ do $1^{\circ}$ período ao $7^{\circ}$ período). Altos valores de coeficientes de variação para os períodos iniciais de avaliação, também, foram obtidos por Bovi et al. (2002) (CV variando de 42,83\% a 29,44\%). Segundo os mesmos autores, esses valores refletem a variabilidade da população em relação à esse caráter. No início do experimento, as plantas apresentavam um número médio de perfilhos de 0,39 com valores bem próximos entre as doses de $\mathrm{N}$ aplicadas, conforme se verifica na Figura 25. E, e ao final do período avaliado, as plantas apresentam-se com 9,64 perfilhos. 


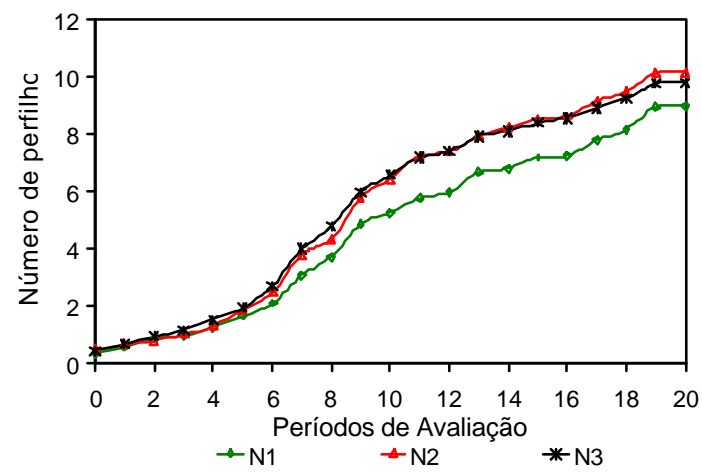

Figura 25 - Número de perfilhos para as das doses de nitrogênio.

Pela Figura 25, é possível constatar ainda que o maior número de perfilhos esteve relacionado às plantas das parcelas que receberam N2 $\left(200 \mathrm{~kg} \mathrm{ha}^{-1} \mathrm{ano}^{-1}\right)$ e N3 (400 kg $\mathrm{ha}^{-1} \mathrm{ano}^{-1}$ ), com aumento sucessivo do número médio de perfilhos em respostas às adubações nitrogenadas recebidas nos períodos de avaliação. Os tratamentos que receberam N1 (testemunha) apresentaram menor número de perfilhos durante o período de aplicação dos tratamentos. A partir do $6^{\circ}$ período (190NDA), começou a ocorreu um maior incremento do número de perfilhos. Por volta do $18^{\circ}$ período (594 NDA), observou-se uma tendência de estabilização, em relação ao número médio de perfilhos obtidos sob os diferentes tratamentos.

$\mathrm{Na}$ Tabela 27 encontram-se os resultados da regressão entre os dados dos tratamentos e o número de perfilhos. A regressão foi linear para lâminas somente em três períodos e com menor grau de significância do que da regressão para nitrogênio, que teve efeitos significativos a partir do sexto período e se mantendo até o último. Do décimo período em diante, a regressão quadrática foi significativa, porém, em menor grau de significância do que a regressão linear.

A Figura 26a ilustra o gráfico da regressão entre as lâminas de irrigação e o número de perfilhos para o $11^{\circ}$ período de avaliação. A equação que representa a resposta em número de perfilhos as lâminas é $\mathrm{Y}=6+0,0025 \mathrm{X}\left(\mathrm{R}^{2}=0,84 \%\right)$, onde o $\mathrm{X}$ é à lâmina aplicada. Para o nitrogênio (Figura 26b), a equação é expressa por $\mathrm{Y}=5,98+$ $0,0035 X\left(R^{2}=0,73 \%\right)$. O coeficiente de determinação obtido para $\mathrm{N}$ teve valor inferior à lâmina. 
$0,0035 X\left(\mathrm{R}^{2}=0,73 \%\right)$. O coeficiente de determinação obtido para $\mathrm{N}$ teve valor inferior à lâmina.

Tabela 27. Resumo da regressão linear e quadrática entre os tratamentos lâminas de irrigação e dosagens de adubação nitrogenada e o número de perfilhos.

\begin{tabular}{|c|c|c|c|c|c|}
\hline \multirow{3}{*}{$\begin{array}{l}\text { Causas de } \\
\text { Variação } \\
\text { Períodos }\end{array}$} & \multicolumn{2}{|c|}{ Lâmina } & \multicolumn{2}{|c|}{ Nitrogênio } & \multirow{2}{*}{$\begin{array}{c}\text { Interação } \\
\text { L x N }\end{array}$} \\
\hline & Linear & Quadrática & Linear & $\begin{array}{c}\text { Quadrátic } \\
\text { a }\end{array}$ & \\
\hline & \multicolumn{5}{|c|}{ Quadrado Médio } \\
\hline 1 & 0,024 & 0,149 & 0,072 & 0,002 & 0,001 \\
\hline 2 & 0,0063 & 0,452 & 0,065 & 0,0917 & 0,0133 \\
\hline 3 & 0,0715 & 0,760 & 0,248 & 0,048 & 0,059 \\
\hline 4 & 0,023 & 1,057 & 0,485 & 0,057 & 0,007 \\
\hline 5 & 0,297 & 0,346 & 0,644 & 0,037 & 0,064 \\
\hline 6 & 1,282 & 0,796 & $2,796 *$ & 0,081 & 0,004 \\
\hline 7 & 1,784 & 0,205 & $6,716^{* *}$ & 0,748 & 0,046 \\
\hline 8 & 2,204 & 0,041 & $9,702 * *$ & 0,057 & 1,292 \\
\hline 9 & $3,673^{*}$ & 0,282 & $9,923 * *$ & 1,455 & 0,024 \\
\hline 10 & 2,811 & 0,209 & $13,623 * *$ & $3,004 *$ & 0,385 \\
\hline 11 & $5,521 *$ & 0,088 & $16,545^{* *}$ & $6,005^{*}$ & 0,143 \\
\hline 12 & $5,132 *$ & 0,072 & $16,107 * *$ & $5,260 *$ & 0,136 \\
\hline 13 & 2,713 & 1,095 & $12,675^{* *}$ & $4,498 *$ & 0,547 \\
\hline 14 & 3,111 & 0,861 & $13,017 * *$ & $6,045^{*}$ & 0,688 \\
\hline 15 & 2,485 & 0,823 & $11,544 * *$ & $6,181^{*}$ & 0,476 \\
\hline 16 & 2,674 & 1,198 & $13,622 * *$ & $5,705^{*}$ & 0,158 \\
\hline 17 & 0,814 & 1,668 & $10,374 * *$ & $7,260 *$ & 0,003 \\
\hline 18 & 0,162 & 2,419 & $9,933 * *$ & $6,516^{*}$ & 0,009 \\
\hline 19 & 1,463 & 2,626 & $5,008^{*}$ & $6,490 *$ & 0,078 \\
\hline
\end{tabular}

* significativo ao nível de $5 \%$ pelo teste $\mathrm{F}$; ** significativo ao nível de $1 \%$ pelo teste $\mathrm{F}$ 


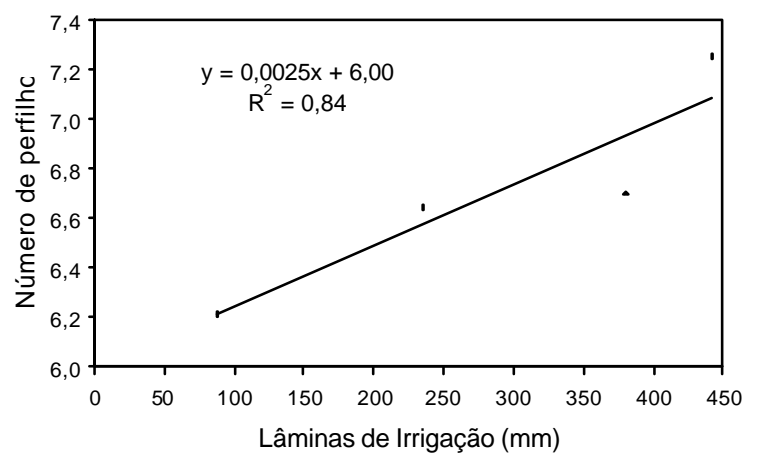

(a)

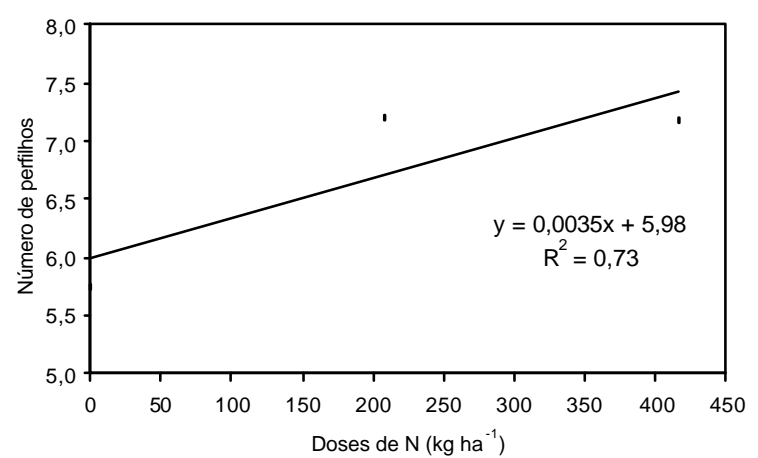

(b)

Figura 26 - Regressão linear: (a) entre as lâminas de irrigação acumuladas e o número de perfilhos; (b) entre os níveis de nitrogênio acumulados e o número de perfilhos, obtidas para o $11^{\circ}$ período.

\subsection{Taxa de crescimento}

A taxa de crescimento absoluto, calculada segundo equação (5), pode ser usada para se ter uma idéia da velocidade de crescimento ao longo do período de observação e pode ser denominada de taxa de crescimento média ou velocidade média de crescimento ao longo do período observado (Benincasa, 1988).

Como a taxa de crescimento corresponde ao incremento obtido entre duas avaliações consecutivas, as regressões feitas para essas variáveis foram calculadas com as quantidades dos tratamentos aplicados em cada período avaliado. Para os demais parâmetros, as regressões foram calculadas em função das quantidades totais acumuladas no período, afinal, trabalhou-se com os totais absolutos de crescimento.

Para o cálculo da taxa de crescimento médio das parcelas que tiveram algumas plantas cortadas nos primeiros cortes, foi feita uma estimativa baseada na taxa de crescimento médio da planta nos quatro meses anteriores ao corte.

\subsubsection{Taxa de crescimento em altura}

Pela Tabela 28, observa-se que as taxas de crescimento em altura foram estatisticamente diferentes $(\mathrm{P}<0,05$ e $\mathrm{P}<0,01)$ entre as lâminas de irrigação e níveis de 
Tabela 28. Análise de variância para taxa de crescimento em altura ( $\mathrm{cm}$ mês $\left.{ }^{-1}\right)$ de planta, nos períodos de avaliação.

\begin{tabular}{|c|c|c|c|c|c|c|c|}
\hline $\begin{array}{c}\text { Causas de } \\
\text { Variação }\end{array}$ & Lâmina & Nitrogênio & $\begin{array}{c}\text { Interação } \\
\text { L x N }\end{array}$ & Blocos & Resíduo & \multirow{3}{*}{$\mathrm{CV}$} & \multirow{2}{*}{ Média } \\
\hline GL & 3 & 2 & 6 & 3 & 33 & & \\
\hline Período & \multicolumn{5}{|c|}{ Quadrado Médio } & & \\
\hline 1 & 0,79 & 0,58 & 0,13 & $6,17 * *$ & 0,47 & 42,00 & 1,64 \\
\hline 2 & $2,57 *$ & 1,53 & 0,43 & 0,50 & 0,67 & 54,45 & 1,51 \\
\hline 3 & 0,26 & $1,46^{*}$ & 0,12 & 0,23 & 0,33 & 55,36 & 1,03 \\
\hline 4 & 0,62 & 1,37 & 0,68 & 0,49 & 0,48 & 34,52 & 2,02 \\
\hline 5 & $7,76 * *$ & $10,99 * *$ & 1,12 & $8,07 * *$ & 1,12 & 22,92 & 4,62 \\
\hline 6 & $23,37 * *$ & 0,81 & 1,94 & 1,32 & 1,74 & 26,84 & 4,91 \\
\hline 7 & 2,24 & 2,05 & 1,35 & 1,29 & 1,49 & 31,07 & 3,93 \\
\hline 8 & 2,31 & $19,44 * *$ & 0,97 & 1,38 & 2,84 & 24,41 & 6,91 \\
\hline 9 & $20,63 * *$ & $39,45 * *$ & 2,62 & $9,74^{*}$ & 2,86 & 17,98 & 9,42 \\
\hline 10 & $20,48 * *$ & $82,83 * *$ & 0,91 & $6,74^{*}$ & 1,98 & 17,19 & 8,19 \\
\hline 11 & $33,36 * *$ & $79,49 * *$ & 2,63 & 9,91 & 3,66 & 22,22 & 8,61 \\
\hline 12 & $14,68 * *$ & $7,44 * *$ & 1,31 & 1,23 & 1,02 & 31,68 & 3,18 \\
\hline 13 & $13,96 * *$ & $22,91 * *$ & 1,49 & 1,60 & 1,31 & 37,83 & 3,03 \\
\hline 14 & $14,69 * *$ & 2,02 & 1,03 & 2,84 & 1,48 & 41,81 & 2,91 \\
\hline 15 & $14,67 * *$ & $7,78 *$ & 3,40 & $7,24 *$ & 1,66 & 32,33 & 3,99 \\
\hline 16 & $16,00 * *$ & $51,48 * *$ & 14,24 & $11,83^{*}$ & 2,78 & 17,34 & 9,6 \\
\hline 17 & $12,81 * *$ & $21,42 * *$ & 5,17 & 6,06 & 2,32 & 17,31 & 8,08 \\
\hline 18 & 1,24 & 4,78 & 8,05 & $17,90 *$ & 5,68 & 22,37 & 10,65 \\
\hline 19 & 0,79 & $42,24 * *$ & 3,62 & 8,29 & 6,64 & 22,89 & 11,26 \\
\hline 20 & 0,24 & $70,64 *$ & 6,98 & 21,60 & 14,90 & 24,01 & 16,03 \\
\hline
\end{tabular}

* significativo a $5 \%$ pelo teste $\mathrm{F}$; ** significativo a $1 \%$ pelo teste $\mathrm{F}$.

adubação nitrogenada em grande parte dos períodos avaliados, evidenciando que as respostas aos tratamentos são mais facilmente identificadas na variável altura do que na variável diâmetro. Os coeficientes de variação obtidos para taxa de crescimento em altura foram, assim como para taxa em diâmetro, bastante elevados, de 17,19\% a $55,36 \%$. Os maiores valores ocorreram, principalmente, nos primeiros períodos avaliados, o que pode ser entendido como uma resposta das plantas aos tratamentos pela diminuição do coeficiente de variação ao longo dos períodos.

Inicialmente, a taxa média de crescimento foi de $1,64 \mathrm{~cm}$ mês ${ }^{-1}$ e foi aumentando a cada período avaliado. Seus valores passaram a ser bem maiores do $5^{\circ}$ período ao $11^{\circ}$ período (Figura 27), estando este intervalo compreendido entre os meses de 
setembro/2000 a abril/2001. Pela Tabela 9, constata-se que nesses meses ocorreram altos valores de temperatura média mensal, radiação global e precipitação pluviométrica, podendo ser tudo isso um indicativo de que a taxa de crescimento da cultura pode ter sido muito influenciada, também, pelos parâmetros climáticos. Diotto et al. (2001) estudando as mesmas plantas observaram que houve uma correlação positiva entre a temperatura e a radiação solar com a taxa de crescimento em altura das plantas. No entanto, não foi possível encontrar um modelo que desse uma boa correlação com a precipitação pluviométrica. Do $12^{\circ}$ período ao $14^{\circ}$ período (abril a julho/2002), as taxas diminuíram bastante e esse decréscimo pode ser atribuído, principalmente, à temperatura que a partir do $12^{\circ}$ período começa a diminuir até chegar a um valor de $18,76^{\circ} \mathrm{C}\left(14^{\circ}\right.$ período - Tabela 9). No $15^{\circ}$ período, os valores de taxa de crescimento voltaram a ser bem mais altos e, ao final a taxa média foi de $16,03 \mathrm{~cm}^{\text {mês }}{ }^{-1}$. Ramos et al. (2002) avaliaram o desenvolvimento vegetativo de uma cultura de pupunheiras com três anos, em Terra Roxa Estruturada, em função de níveis de depleção de água no solo e encontraram uma taxa média de crescimento em altura variando de $10,45 \mathrm{~cm}^{\text {mês }}{ }^{-1}$ a $15,12 \mathrm{~cm}$ mês $^{-1}$ para o tratamento com maior intensidade de aplicação de água (25\% $\mathrm{AD}$ ). É pertinente recordar que ao comparar esses resultados com os do presente trabalho, é necessário observar que as plantas estavam em idade de campo diferente e foram avaliados somente seis meses (agosto/1997 a janeiro/1998).

Os tratamentos que proporcionaram as maiores taxas de crescimento em altura, durante grande parte dos períodos avaliados foram L3 e L4 e a menores taxas ocorreram em L1 (Figura 27a). Já, para nitrogênio, as melhores dosagens foram N2 e N3, sendo que as plantas do tratamento $\mathrm{N} 1$ foram as que tiveram as menores taxas de crescimento durante todo o tempo de avaliação (Figura 27b) 


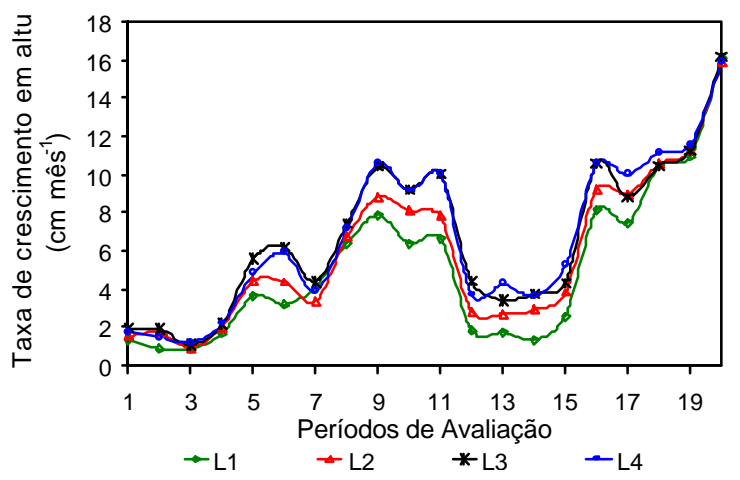

(a)

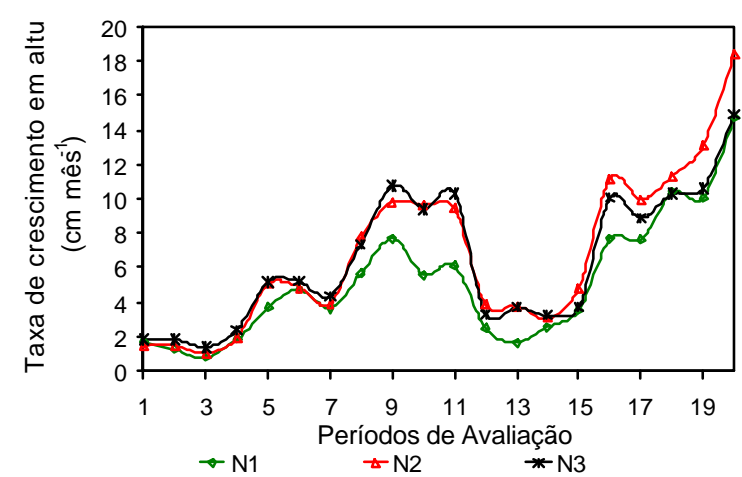

(b)

Figura 27 - Taxa de crescimento $(\mathrm{cm})$ médio em altura em função das lâminas de irrigação (a) e das doses de nitrogênio.

Pela Tabela 29, é possível perceber que somente no período dois ocorre um efeito quadrático para lâminas. Enquanto efeitos lineares estavam presentes em grande parte dos períodos estudados (do $4^{\circ}$ período, $5^{\circ}$ período e do $9^{\circ}$ período ao $17^{\circ}$ período). Esses resultados levam a assumir que níveis crescentes de irrigação acarretam aumentos também crescentes na taxa de crescimento em altura.

A Figura 27a representa o gráfico da regressão obtida entre as lâminas e a taxa de crescimento em altura para o $10^{\circ}$ período e seus efeitos podem ser equacionados por $\mathrm{Y}=$ $5,75+0,07 \mathrm{X}\left(\mathrm{R}^{2}=94 \%\right)$. As lâminas L3 e L4 têm uma taxa de crescimento muito semelhante em resposta às quantidades aplicadas nestes tratamentos. Já, comparativamente a de L1 é muito inferior a de L3 e L4.

Para nitrogênio, os efeitos lineares começaram a se manifestar a partir do $2^{\circ}$ período e em grande parte dos períodos estudados (em 12 períodos). Do $8^{\circ}$ período em diante, surgem os efeitos quadráticos, entretanto, em magnitude superior para os efeitos lineares. A equação que representa a resposta em taxa de crescimento às doses de $\mathrm{N}$ é dada por $\mathrm{Y}=6,28+0,0519 \mathrm{X}\left(\mathrm{R}^{2}=0,71 \%\right)$. A maior taxa de crescimento em altura ocorreu em N2, conforme se observa na Figura 28b. 
Tabela 29. Resumo da regressão linear e quadrática entre os tratamentos lâminas de irrigação e dosagens de adubação nitrogenada e a taxa de crescimento em altura.

\begin{tabular}{cccccc}
\hline $\begin{array}{c}\text { Causas de } \\
\text { Variação }\end{array}$ & $\begin{array}{c}\text { Linear } \\
\text { Nitrogênio }\end{array}$ & $\begin{array}{c}\text { Quadrática } \\
\text { Nitrogênio }\end{array}$ & $\begin{array}{c}\text { Linear } \\
\text { Lâmina }\end{array}$ & $\begin{array}{c}\text { Quadrática } \\
\text { Lâmina }\end{array}$ & $\begin{array}{c}\text { Interação } \\
\text { L x N }\end{array}$ \\
\hline Períodos & \multicolumn{5}{c}{ Quadrado Médio } \\
\hline 1 & 0,1126 & 1,0831 & 1,8242 & 0,0989 & 0,2427 \\
2 & $3,0112^{*}$ & 0,0380 & 3,6849 & $3,7629 * *$ & 0,4177 \\
3 & $2,9203 * *$ & 0,0129 & 0,7673 & 0,0578 & 0,0210 \\
4 & $2,2836^{*}$ & 0,4241 & 1,6944 & 0,1677 & 0,0849 \\
5 & $17,7310^{* *}$ & 4,2588 & $17,3070^{* *}$ & 1,2865 & 0,0537 \\
6 & 1,6083 & 0,1499 & $65,9101 * *$ & 0,4742 & 4,5919 \\
7 & 4,0091 & 0,0976 & 0,1117 & 1,6770 & 0,7753 \\
8 & $22,4165^{* *}$ & $16,4830^{*}$ & 5,7835 & 0,0884 & 0,9134 \\
9 & $75,8741^{* *}$ & 3,1637 & $60,5949^{* *}$ & 0,0769 & 0,0078 \\
10 & $117,2743^{* *}$ & $48,1940^{* *}$ & $58,0979^{* *}$ & 3,2739 & 1,5996 \\
11 & $142,9402^{* *}$ & $15,8876^{*}$ & $96,1771^{* *}$ & 0,0698 & 3,2153 \\
12 & $5,0696^{*}$ & $9,9287^{* *}$ & $36,9408^{* *}$ & 1,7716 & 0,0031 \\
13 & $32,7018^{* *}$ & $13,1120^{* *}$ & $40,6716^{* *}$ & 0,2918 & 1,6204 \\
14 & 3,7032 & 0,3015 & $40,4742^{* *}$ & 3,4379 & 0,1018 \\
15 & 0,1981 & $15,2960^{*}$ & $42,0436^{* *}$ & 0,0056 & 0,0033 \\
16 & $44,7915^{* *}$ & $57,9713^{* *}$ & $46,5309^{* *}$ & 0,3565 & 0,1981 \\
17 & $12,5100^{*}$ & $30,5823^{* *}$ & $30,6238^{* *}$ & 0,3482 & 6,7471 \\
18 & 0,0361 & 9,6476 & 1,4892 & 0,7772 & 0,5937 \\
\hline
\end{tabular}

* significativo a $5 \%$ pelo teste $\mathrm{F}$; **significativo a $1 \%$ pelo teste $\mathrm{F}$.

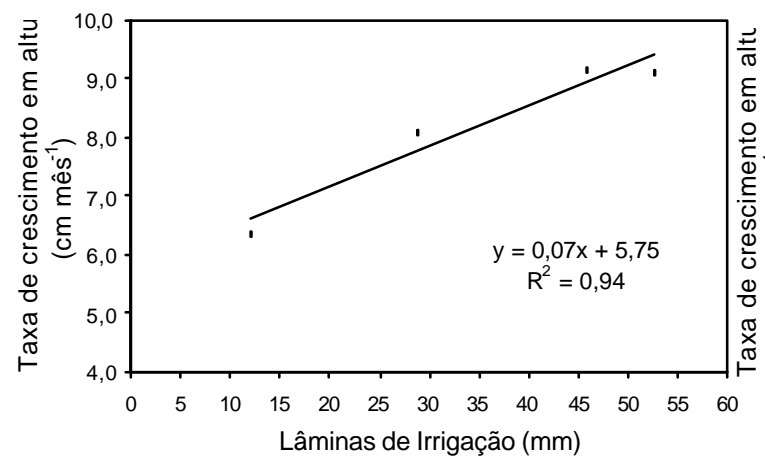

(a)

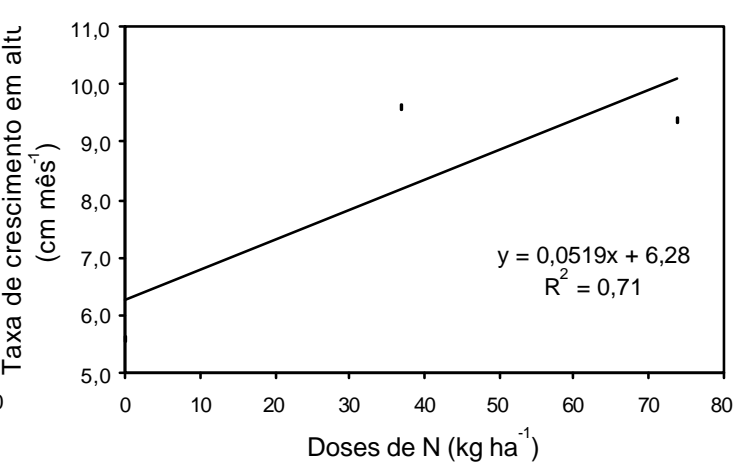

(b)

Figura 28 - Regressão linear: (a) entre as lâminas de irrigação acumuladas e a taxa de crescimento em altura; (b) entre os níveis de nitrogênio acumulados e a taxa de crescimento em altura, obtidas para o $10{ }^{\circ}$ período. 


\subsubsection{Taxa de crescimento em diâmetro}

A Tabela 30 contém um resumo da análise de variância para taxa de crescimento em diâmetro para todos os períodos avaliados. Por esta, é possível verificar que houve diferença significativa $(\mathrm{P}<0,05$ e $\mathrm{P}<0,01)$ entre os tratamentos a partir do sexto período (190 NDA) até o $16^{\circ}$ período (531 NDA), com uma alternância entre lâminas e dosagens de nitrogênio em alguns períodos e concomitantes nos períodos 7, 9, 10 e 12. Estes resultados podem ser atribuídos à dificuldade de se medir o diâmetro do colo, uma vez que em plantas jovens este diâmetro acaba englobando diferentes partes da planta como pecíolos e bainhas e não somente a estipe. Dificuldade esta encontrada também em outro trabalho desenvolvido por Clement \& Bovi (1998) sobre padronização de medidas de crescimento para pupunheiras.

Tabela 30. Resumo da análise de variância para taxa de crescimento em diâmetro (cm mês ${ }^{-1}$ ) de planta, nos períodos de avaliação.

\begin{tabular}{|c|c|c|c|c|c|c|c|}
\hline $\begin{array}{c}\text { Causas de } \\
\text { Variação }\end{array}$ & Lâmina & Nitrogênio & $\begin{array}{c}\text { Interação } \\
\text { L x N }\end{array}$ & Blocos & Resíduo & \multirow{3}{*}{$\mathrm{CV}$} & \multirow{2}{*}{ Média } \\
\hline GL & 3 & 2 & 6 & 3 & 33 & & \\
\hline Período & \multicolumn{5}{|c|}{ Quadrado Médio } & & \\
\hline 1 & 0,016 & 0,024 & 0,010 & 0,012 & 0,015 & 37,10 & 0,33 \\
\hline 2 & 0,019 & 0,017 & 0,024 & $0,153 * *$ & 0,013 & 30,03 & 0,39 \\
\hline 3 & 0,009 & $0,071 * *$ & 0,005 & $0,042 *$ & 0,009 & 30,83 & 0,32 \\
\hline 4 & 0,014 & 0,004 & 0,004 & 0,012 & 0,008 & 35,72 & 0,26 \\
\hline 5 & 0,007 & 0,003 & 0,003 & 0,015 & 0,004 & 27,65 & 0,24 \\
\hline 6 & $0,082 * *$ & 0,014 & 0,017 & 0,012 & 0,009 & 29,63 & 0,32 \\
\hline 7 & $0,035^{*}$ & $0,047 *$ & 0,005 & 0,027 & 0,011 & 29,50 & 0,35 \\
\hline 8 & 0,030 & $0,090 *$ & 0,016 & $0,061 *$ & 0,018 & 30,55 & 0,45 \\
\hline 9 & $0,237 * *$ & $0,306 * *$ & 0,016 & 0,049 & 0,029 & 22,54 & 0,77 \\
\hline 10 & $0,068 * *$ & $0,173 * *$ & 0,011 & $0,056 * *$ & 0,013 & 19,92 & 0,56 \\
\hline 11 & 0,0823 & 0,090 & 0,033 & 0,072 & 0,031 & 30,20 & 0,58 \\
\hline 12 & $0,0387 *$ & $0,063 * *$ & 0,016 & $0,058 * *$ & 0,011 & 26,65 & 0,39 \\
\hline 13 & $0,111 * *$ & 0,035 & 0,042 & $0,118 * *$ & 0,021 & 27,01 & 0,34 \\
\hline 14 & $0,097 * *$ & 0,020 & 0,006 & 0,024 & 0,015 & 32,79 & 0,37 \\
\hline 15 & 0,043 & $0,074^{*}$ & 0,046 & $0,064 *$ & 0,017 & 30,15 & 0,43 \\
\hline 16 & 0,012 & $0,049 * *$ & 0,005 & 0,014 & 0,008 & 21,43 & 0,43 \\
\hline 17 & 0,004 & 0,004 & 0,008 & $0,067 * *$ & 0,005 & 22,69 & 0,33 \\
\hline 18 & 0,025 & 0,006 & 0,024 & 0,022 & 0,022 & 35,66 & 0,42 \\
\hline 19 & 0,015 & 0,002 & 0,010 & $0,162 * *$ & 0,013 & 32,12 & 0,35 \\
\hline 20 & 0,039 & 0,008 & 0,019 & $0,352 * *$ & 0,030 & 34,35 & 0,50 \\
\hline
\end{tabular}

* significativo a $5 \%$ pelo teste $\mathrm{F}$; **significativo a $1 \%$ pelo teste $\mathrm{F}$. 
Nos períodos 6 ao 11, ocorreram as maiores taxas médias de crescimento em diâmetro, variando de $0,32 \mathrm{~cm} \mathrm{mês}^{-1}$ a $0,58 \mathrm{~cm} \mathrm{mês}^{-1}$, entre os meses de outubro/2000 a abril/2001. Neste intervalo, registraram-se as maiores temperaturas médias $\left(22,14^{\circ} \mathrm{C}\right.$ a $24,58^{\circ} \mathrm{C}$ ) considerando todos os períodos estudados (Tabela 9). Este comportamento foi o mesmo que para outros parâmetros como número de folhas e folhas novas, onde os maiores acréscimos foram obtidos nos meses de temperaturas mais elevadas, associadas a altos índices de umidades relativas e radiação global. Em tal intervalo, também foram observados os menores coeficientes de variação $(19,92 \%$ a 30,55\%), quando comparados aos primeiros e aos últimos períodos (30,03\% e 37,10\%). Ademais, os coeficientes de variação foram altos em todos os períodos.

As figuras abaixo representam a curva de crescimento para os tratamentos lâminas de irrigação (Figura 29a) e doses de nitrogênio (Figura 29b). Verifica-se que as maiores taxas de crescimento foram a dos tratamentos L3 e L4 até o período 15 e, ao final (período 20), as taxas de crescimento foram aproximadamente iguais entre os tratamentos L2, L3 e L4. E somente L1 teve a menor taxa de crescimento durante todo o período avaliado, assim como N1.

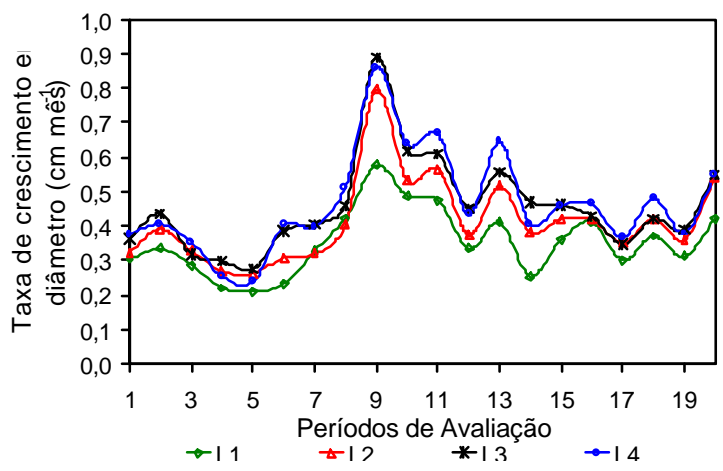

(a)

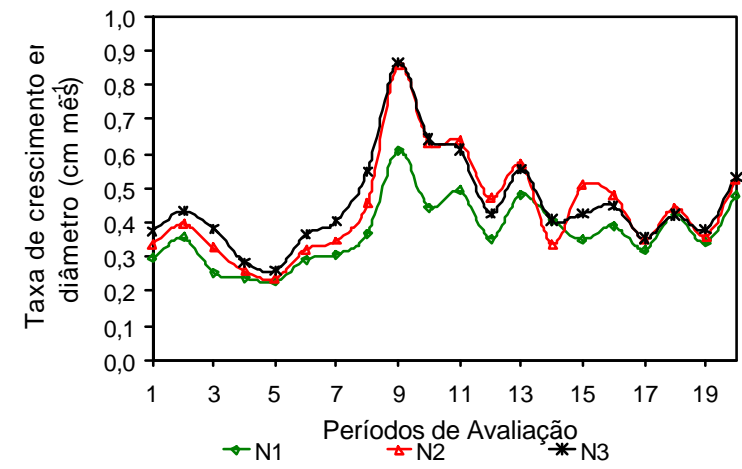

(b)

Figura 29 - Taxa de crescimento $(\mathrm{cm})$ médio em diâmetro em função das lâminas de irrigação (a) e das doses de nitrogênio (b).

Os tratamentos, lâminas e doses de nitrogênio começaram a apresentar efeitos sobre a taxa de crescimento em diâmetro de planta a partir do terceiro período de 
avaliação (Tabela 31). Independentemente às respostas, os efeitos lineares e quadráticos tiveram uma tendência de se concentrarem, principalmente, entre o sexto e décimo sexto períodos.

Tabela 31. Resumo da regressão linear e quadrática entre os tratamentos lâminas de irrigação e dosagens de adubação nitrogenada e a taxa de crescimento em diâmetro de planta.

\begin{tabular}{cccccc}
\hline $\begin{array}{c}\text { Causas de } \\
\text { Variação }\end{array}$ & $\begin{array}{c}\text { Linear } \\
\text { Nitrogênio }\end{array}$ & $\begin{array}{c}\text { Quadrática } \\
\text { Nitrogênio }\end{array}$ & $\begin{array}{c}\text { Linear } \\
\text { Lâmina }\end{array}$ & $\begin{array}{c}\text { Quadrátic } \\
\text { a } \\
\text { Lâmina }\end{array}$ & $\begin{array}{c}\text { Interação } \\
\text { L x N }\end{array}$ \\
\hline Período & \multicolumn{5}{c}{ Quadrado Médio } \\
\hline 1 & 0,0535 & 0,00007 & 0,0436 & 0,0054 & 0,0038 \\
2 & 0,03418 & 0,0005 & 0,0514 & 0,0099 & 0,0037 \\
3 & $0,1397 * *$ & 0,0004 & 0,0220 & 0,0006 & 0,0010 \\
4 & 0,0099 & 0,0001 & 0,0162 & 0,0132 & 0,0119 \\
5 & 0,0091 & 0,0008 & 0,0126 & 0,0059 & 0,00008 \\
6 & 0,0319 & 0,0001 & $0,2383^{*} *$ & 0,0025 & 0,0004 \\
7 & $0,0881 * *$ & 0,014 & $0,0622^{*}$ & 0,0219 & 0,0013 \\
8 & $0,1798^{*} *$ & 0,0013 & 0,0589 & 0,0371 & 0,00002 \\
9 & $0,4204 * *$ & $0,1965 *$ & $0,6771 * *$ & 0,0394 & 0,0013 \\
10 & $0,2262 * *$ & $0,1142 * *$ & $0,1885 * *$ & 0,0074 & 0,0090 \\
11 & 0,1124 & 0,0784 & $0,2299^{*} *$ & 0,0004 & 0,0474 \\
12 & 0,0009 & $0,1284 * *$ & $0,0965 * *$ & 0,0003 & 0,0028 \\
13 & 0,0392 & 0,0304 & $0,3107 * *$ & 0,000001 & 0,0277 \\
14 & 0,0169 & 0,0221 & $0,2284 * *$ & 0,0492 & 0,0025 \\
15 & $0,1456 *$ & 0,0018 & 0,0319 & 0,0515 & 0,0742 \\
16 & $0,0901 * *$ & 0,0048 & 0,0066 & 0,0220 & 0,0019 \\
17 & 0,0009 & 0,0064 & 0,0063 & 0,0033 & 0,0017 \\
18 & 0,0148 & 0,00001 & 0,0411 & 0,0232 & 0,0095 \\
\hline
\end{tabular}

* significativo a $5 \%$ pelo teste $\mathrm{F}$; $* *$ significativo a $1 \%$ pelo teste $\mathrm{F}$.

Em relação à taxa de crescimento em altura, para este parâmetro, foi detectado efeito linear significativo em um menor número de períodos (em 8 períodos). Mas os efeitos quadráticos aparecem em três períodos (9, 10 e 12). E, assim como aconteceu para a taxa de crescimento em altura, a magnitude da regressão linear foi superior à quadrática (Tabela 31). O coeficiente de determinação obtido para a regressão realizada no $11^{\circ}$ período foi de $\mathrm{R}^{2}=0,94 \%$ (Figura 30a). 


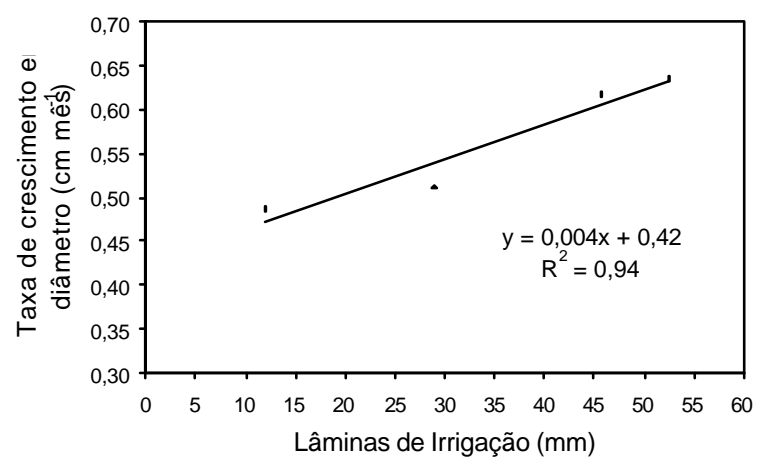

(a)

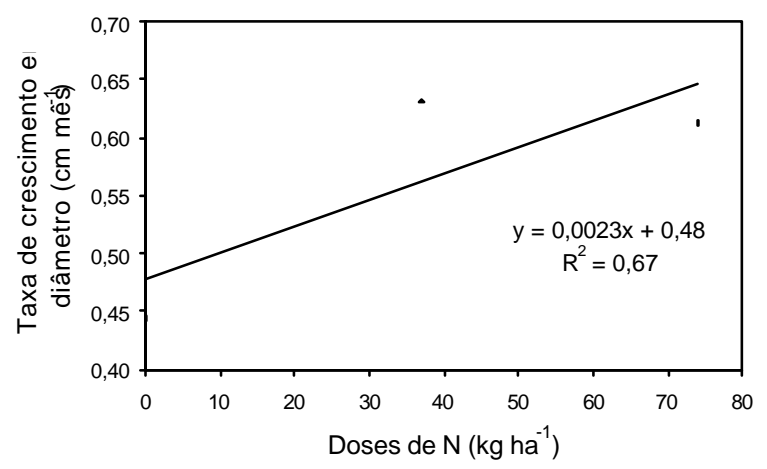

(b)

Figura 30 - Regressão linear: (a) entre as lâminas de irrigação acumuladas e a taxa de crescimento em diâmetro; (b) entre os níveis de nitrogênio acumulados e a taxa de crescimento em diâmetro, obtidas para o $11^{\circ}$ período.

O nitrogênio apresentou efeitos lineares do $7^{\circ}$ período ao $10^{\circ}$ período e, quadráticos, do $9^{\circ}$ período ao $12^{\circ}$ período. (Figura 30b). Mais uma vez, como para lâminas, seus efeitos lineares foram superiores aos quadráticos. $O$ coeficiente de determinação obtido foi menor $\left(\mathrm{R}^{2}=0,64 \%\right)$ ao da taxa de crescimento em altura.

\section{6 Área foliar}

A Tabela 32 representa um resumo da análise de variância do índice de área foliar no período pesquisado. Por esta tabela, nota-se que para o parâmetro índice de área foliar houve efeito significativo $(\mathrm{P}<0,01)$ entre os tratamentos níveis de irrigação e doses de adubação nitrogenada, com ausência de interação significativa para a combinação lâmina x nitrogênio $(\mathrm{P}>0,01)$. 
Tabela 32. Análise de variância para índice de área foliar $\left(\mathrm{m}^{2}\right)$, no $15^{\circ}$ período (499NDA).

\begin{tabular}{cccc}
\hline \multirow{2}{*}{ Causas de Variação } & \multirow{2}{*}{ GL } & \multicolumn{2}{c}{ Índice de Área foliar $\left(\mathrm{m}^{2}\right)$} \\
\cline { 3 - 4 } & & $\mathrm{QM}$ & $\mathrm{P}$ \\
\hline Lâmina & 3 & 0,7102 & $0,0019^{* *}$ \\
Nitrogênio & 2 & 0,6963 & $0,0037^{* *}$ \\
L x N & 6 & 0,0343 & 0,8100 \\
\hline Tratamento & 11 & 0,3119 & $0,0100^{* *}$ \\
Bloco & 1 & 0,040 & 0,4699 \\
Resíduo & 12 & 0,0714 & \\
\hline CV $(\%)$ & 14.72 & & \\
\hline
\end{tabular}

**significativo ao nível de $1 \%$ pelo teste $\mathrm{F}$

Ao passo que pela Tabela 33, observa-se que houve efeito linear significativo para as lâminas de irrigação aplicadas, assim como para doses de nitrogênio. Não houve efeitos quadráticos e nem interação significativa entre lâmina x nitrogênio.

Tabela 33. Análise de regressão para índice de área foliar $\left(\mathrm{m}^{2}\right)$, no $15^{\circ}$ período (499NDA).

\begin{tabular}{cccc}
\hline \multirow{2}{*}{ Causas de Variação } & \multirow{2}{*}{ GL } & \multicolumn{2}{c}{ Índice de Área Foliar $\left(\mathrm{m}^{2}\right)$} \\
\cline { 3 - 4 } & & QM & P>F \\
\hline Tratamento & 6 & 0,5765 & $0,0001^{* *}$ \\
Resíduo & 17 & 0,0629 & \\
\hline Bloco & 1 & 0,0400 & 0,4362 \\
Linear Lâmina & 1 & 1,4897 & $0,0001^{* *}$ \\
Quadrática Lâmina & 1 & 0,1761 & 0,1127 \\
Linear Nitrogênio & 1 & 1,3924 & $0,0002^{* *}$ \\
Quadrática Nitrogênio & 1 & 0,0001 & 0,9639 \\
L x N & 1 & 0,0011 & 0,8977 \\
\hline CV $(\%)$ & 13,82 & & \\
\hline
\end{tabular}

**significativo ao nível de $1 \%$ pelo teste $\mathrm{F}$

A Figura 31a ilustra a regressão linear entre as lâminas de irrigação aplicadas e o índice de área foliar. Por esta, é possível verificar que a regressão foi linear e com aumentos crescentes no valor do IAF, a medida em que se aumentava a lâmina de irrigação. O maior valor de $\operatorname{IAF}\left(2,13 \mathrm{~m}^{2}\right)$ foi alcançado em L3 (100\%ETo), acima do 
tratamento L4 com $1,99 \mathrm{~m}^{2}$ para a lâmina de $120 \%$ ETo. Este resultado era esperado, uma vez que também ocorreram efeitos lineares para o comprimento de folha em todos os períodos avaliados (do $8^{\circ}$ período ao $19^{\circ}$ período). Para L1 (testemunha), que recebeu água somente pela fertirrigação, com um total de $144 \mathrm{~mm}$ aplicados durante todo o período irrigado, registrou-se o menor valor de $\operatorname{IAF}\left(1,35 \mathrm{~m}^{2}\right)$. Clement et al. (1985) utilizaram metodologia indireta para estimar o IAF de pupunheiras adultas, cultivadas num espaçamento de $5 \mathrm{~m}$ x $5 \mathrm{~m}$ e encontraram valor de 2,72 mí. Já, para Martel \& Clement (1986/87) esses valores variaram de 3,02 $\mathrm{m}^{2}$ a 3,74 $\mathrm{m}^{2}$. Ressalve-se que estes dois trabalhos foram realizados com plantas adultas. Estes autores afirmam que essas variações, como por exemplo, comprimento da ráquis e o número de folíolos, observadas dentro de uma mesma progênie podem ser atribuídas a fatores ambientais. Também avaliam que o IAF pode variar com a idade da planta, espaçamento, fertilidade do solo, entre outros fatores.

Para nitrogênio, notou-se a mesma tendência que para lâminas, com efeitos lineares das dosagens aplicadas sobre o índice de área foliar. Conforme seria previsível afirmar, o maior IAF obtido foi para a maior dosagem de nitrogênio $\left(\mathrm{N} 3=400 \mathrm{~kg} \mathrm{ha}^{-1}\right.$ ano $^{-1}$ ) (Figura 31b).

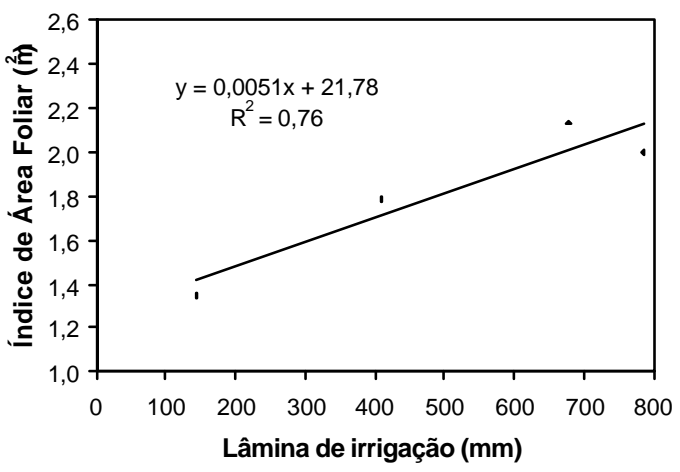

(a)

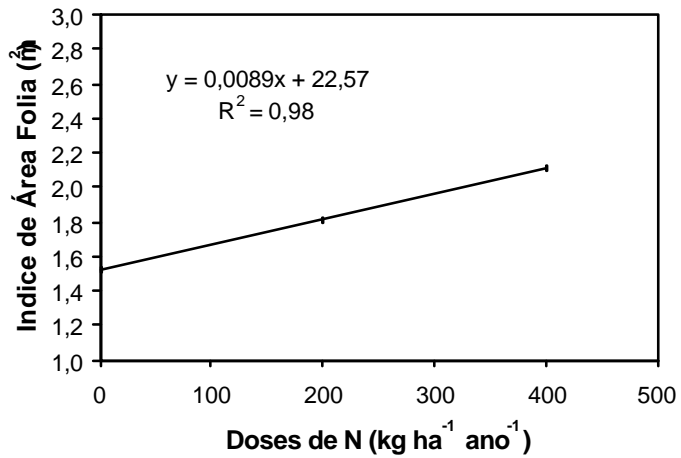

(b)

Figura 31 - Regressão linear: (a) entre as lâminas de irrigação acumuladas e o índice de área foliar $\left(\mathrm{m}^{2}\right)$; (b) entre os níveis de nitrogênio acumulados e o índice de área foliar $\left(\mathrm{m}^{2}\right)$, estimado aos 499 NDA. 


\subsection{Colheita}

Segundo Bovi (1998), a colheita no Brasil é efetuada por volta dos 18 meses aos 36 meses do plantio, dependendo das condições locais de cultivo. Para as condições estudadas, o corte se iniciou por volta dos 30 meses de plantio, quando as plantas estavam com 1,60 m de altura e o diâmetro da plantacm de altura) variando de $9 \mathrm{~cm}$ a 12 cm. Os totais de plantas cortadas por tratamento assim como as porcentagens, são apresentadas na tabela abaixo.

Tabela 34. Número e porcentagem de plantas cortadas por tratamento.

\begin{tabular}{ccccccc}
\hline Datas & $25 / 10 / 01$ & $18 / 12 / 01$ & $22 / 01 / 02$ & $25 / 02 / 02$ & \multirow{2}{*}{ Total } & \multirow{2}{*}{$\begin{array}{c}\% \text { Corte }(40 \\
\text { plantas úteis })\end{array}$} \\
\cline { 1 - 4 } Tratamentos & $1 .{ }^{\circ}$ Corte & $2 .{ }^{\circ}$ Corte & $3 .{ }^{\circ}$ Corte & $4 .{ }^{\circ}$ Corte & & \\
\cline { 1 - 3 } L4N3 & 10 & 7 & 5 & 8 & 30 & 75 \\
L4N2 & 10 & 12 & 4 & 10 & 36 & 90 \\
L4N1 & 3 & 3 & 4 & 6 & 16 & 40 \\
L3N3 & 8 & 7 & 4 & 4 & 23 & 58 \\
L3N2 & 13 & 6 & 10 & 8 & 37 & 93 \\
L3N1 & 2 & 1 & 8 & 8 & 19 & 48 \\
L2N3 & 3 & 8 & 6 & 5 & 23 & 58 \\
L2N2 & 4 & 5 & 4 & 10 & 22 & 55 \\
L2N1 & 1 & 0 & 2 & 0 & 3 & 8 \\
L1N3 & 5 & 2 & 4 & 1 & 12 & 30 \\
L1N2 & 0 & 3 & 4 & 10 & 17 & 43 \\
L1N3 & 0 & 0 & 3 & 3 & 6 & 15 \\
Total & 59 & 54 & 58 & 73 & 244 & 51 \\
\hline
\end{tabular}

Os tratamentos que proporcionaram o corte de um maior número de plantas, em relação ao total de plantas úteis/tratamento (40 plantas), foram L4N3 (75\%), L4N2 (90\%) e L3N2 (93\%) (Tabela 34). Ao final do experimento, em função dos tratamentos aplicados, penas $51 \%$ das plantas úteis atingiram altura de corte. Apesar dos tratamentos L4 (120\%ETo) e L3 (100\%ETo) mostraram bons resultados, variando de 40\% a $93 \%$ de corte, L2 (50\%ETo) e L1 (testemunha) tiveram um índice de apenas $8 \%$ a $58 \%$ de corte. Fixando-se as lâminas de irrigação, observa-se nos tratamentos que receberam $200 \mathrm{~kg}$ $\mathrm{ha}^{-1} \mathrm{ano}^{-1}(\mathrm{~N} 2)$ uma maior percentagem de corte. Ao passo que os tratamentos que não 
receberam adubação nitrogenada (N1=testemunha) apresentaram um número pequeno de plantas aptas para o corte. Esses tratamentos com déficit hídrico ou ausência de adubação nitrogenada acarretaram um menor crescimento da planta e, consequientemente, atraso no corte. Afinal, na ausência de adubação nitrogenada, a deficiência em nitrogênio é pronunciada e, como era de se esperar, as aplicações de nitrogênio têm efeitos significativos sobre o crescimento vegetativo de palmeiras (Rodrigues et al.,1997, Tampubolon et al., 1990 e Bonneau et al., 1993).

\subsection{Produtividade}

A produtividade pode ser um bom indicador de resposta aos tratamentos aplicados, uma vez que é muito influenciada pela deficiência hídrica (Bovi, 1998, Alves Júnior et al., 2000).

Para avaliação da produtividade optou-se pela massa fresca de palmito, expressa por planta e por área $\left(\mathrm{kg} \mathrm{ha}^{-1}\right)$, separada em palmito de primeira e de segunda, peso bruto e diâmetro do palmito, segundo recomendação em Clement \& Bovi (2000). Foram considerados palmitos de primeira os toletes de $9 \mathrm{~cm}$ de comprimento, completos e sem defeitos físicos ou mecânicos. Para a produção do palmito de segunda, foram contabilizadas as partes referentes ao estipe tenro ou também chamado de resíduo basal e a folha tenra, ou resíduo apical.

A Tabela 35 representa a análise de variância para os parâmetros de produtividade avaliados. Por esta, constata-se que houve efeito significativo entre lâminas para os parâmetros de produtividade, com exceção do diâmetro médio de palmito, cujo CV (9,95\%) foi muito pequeno. Para nitrogênio, o efeito foi significativo em todos os parâmetros. Já a interação lâmina x nitrogênio não foi significativa.

Tabela 36 representa a análise de regressão entre os tratamentos lâminas e dosagens de nitrogênio e os parâmetros empregados para avaliação da produtividade: peso bruto, peso do palmito de primeira, palmito de segunda e peso total do palmito (ton $\mathrm{ha}^{-1}$ ) e diâmetro médio do palmito $(\mathrm{cm})$. Por esta tabela constata-se que houve efeitos 
Tabela 35. Análise de variância para peso bruto, palmito de primeira, palmito de segunda e peso total de palmito (ton $\mathrm{ha}^{-1}$ ) e diâmetro médio do palmito $(\mathrm{cm})$.

\begin{tabular}{lcccccc}
\hline \multirow{2}{*}{$\begin{array}{l}\text { Causas de } \\
\text { variação }\end{array}$} & GL & Peso bruto & $\begin{array}{c}\text { Palmito de } \\
\text { Primeira }\end{array}$ & $\begin{array}{c}\text { Palmito de } \\
\text { Segunda }\end{array}$ & $\begin{array}{l}\text { Palmito } \\
\text { Total }\end{array}$ & $\begin{array}{c}\text { Diâmetro } \\
\text { médio }\end{array}$ \\
\cline { 3 - 7 } Lâmina & 3 & $373,26^{* *}$ & $0,1104^{* *}$ & $0,7230^{* *}$ & $1,3224^{* *}$ & 0,1165 \\
Nitrogênio & 2 & $388,25^{* *}$ & $0,4136^{* *}$ & $1,3853^{* *}$ & $3,2494^{* *}$ & $0,9009^{* *}$ \\
L x N & 6 & 9,05 & 0,0142 & 0,0771 & 0,1064 & 0,0042 \\
Bloco & 3 & 38,84 & 0,0934 & 0,1946 & 0,1076 & $0,5689^{* *}$ \\
Resíduo & 33 & 28,43 & 0,0351 & 0,1264 & 0,2535 & 0,0809 \\
C.V. & 22,40 & 19,62 & 25,00 & 21,18 & 9,95 \\
$\begin{array}{l}\text { Média (ton } \\
\text { ha }{ }^{-1} \text { e cm) }\end{array}$ & 23,80 & 0,95 & 1,42 & 2,37 & 2,86 \\
**significativo ao nível de 1\% pelo teste F & & & & \\
\hline
\end{tabular}

Tabela 36. Análise de regressão entre os tratamentos aplicados e o peso bruto, do palmito de primeira, palmito de segundo e peso total de palmito (ton $\mathrm{ha}^{-1}$ ) e diâmetro médio do palmito (cm) para 664 NDA (período 16).

\begin{tabular}{ccccccc}
\hline & \multicolumn{7}{c}{ Quadrado Médio } \\
Causas de Variação & GL & \multicolumn{5}{c}{ Peso (ton ha $\left.{ }^{-1}\right)$} \\
& & Bruto & Palmito & Palmito & Total & Diâmetro \\
& & Primeira & Segunda & & $(\mathrm{cm})$ \\
\hline Linear Lâmina & 1 & $1084,54^{* *}$ & $0,2142^{*}$ & $2,0656^{* *}$ & $3,5530^{* *}$ & 0,2789 \\
Quadrática Lâmina & 1 & 6,3052 & 0,0280 & 0,000008 & 0,0258 & 0,0003 \\
Linear Nitrogênio & 1 & $613,53^{* *}$ & $0,5277^{* *}$ & $0,9136^{* *}$ & $2,8615^{* *}$ & $1,3243^{* *}$ \\
Quadrática Nitrogênio & 1 & $162,96^{*}$ & $0,3044^{* *}$ & $1,8569^{* *}$ & $3,6372^{* *}$ & $0,4774^{* *}$ \\
L x N & 1 & 6,0042 & 0,0031 & 0,2256 & 0,3016 & 0,0578 \\
\hline
\end{tabular}

*significativo ao nível de $5 \%$ pelo teste $\mathrm{F}$; **significativo ao nível de $1 \%$ pelo teste $\mathrm{F}$

lineares e quadráticos para doses de nitrogênio e para todos os parâmetros de produtividade.Com exceção do diâmetro médio do palmito, todos os demais apresentaram efeitos lineares para lâminas de irrigação. A interação lâmina $\mathrm{x}$ nitrogênio não teve efeitos lineares significativos para nenhum dos parâmetros avaliados. 
A Figura 32 ilustra a análise de regressão entre peso bruto e os tratamentos. As lâminas totais de irrigação aplicadas durante todos os períodos avaliados foram de 144,00 mm, 410,26 mm, 678,08 mm e 784,26 mm, correspondentes aos tratamentos L1, L2, L3 e L4, respectivamente (Tabela 10). Para lâminas de irrigação (Figura 32a), a regressão foi linear, com aumentos crescentes no peso bruto do palmito em relação às quantidades também crescentes de lâminas aplicadas. $\mathrm{O}$ maior peso bruto de palmito foi obtido para o tratamento L3 (100\%ETo), com 28,46 ton ha ${ }^{-1}$, seguido por L4, L2 e L1 com os valores de 28,10 ton $\mathrm{ha}^{-1}, 21,86$ ton $\mathrm{ha}^{-1}$ e 16,78 ton $\mathrm{ha}^{-1}$, respectivamente. Como se verifica os valores de peso bruto total de palmito foram bem próximos em L3 e L4, não havendo diferença estatística significativa entre os mesmos.

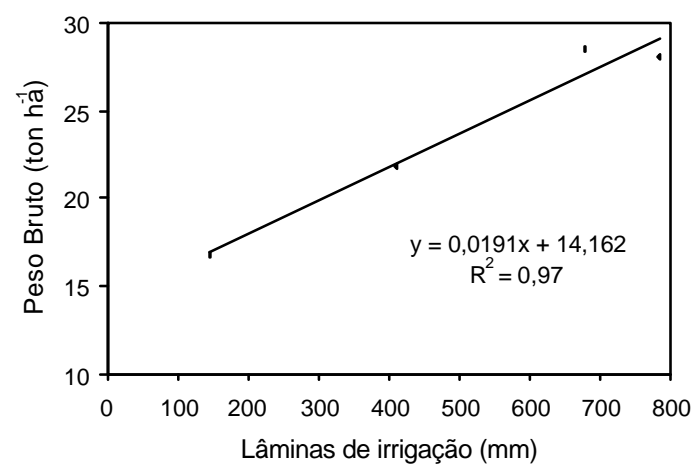

(a)

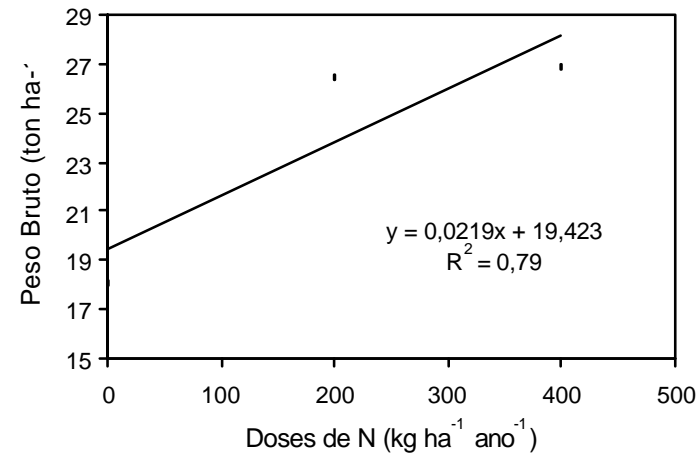

(b)

Figura 32 - Regressão linear: (a) entre as lâminas de irrigação acumuladas e o peso bruto (ton $\mathrm{ha}^{-1}$ ); (b) entre os níveis de nitrogênio acumulados e o peso bruto (ton $\mathrm{ha}^{-1}$ ), estimado aos 664 NDA.

Para nitrogênio, a regressão foi tanto linear, como quadrática, com um grau de significância maior para a linear. A maior produtividade foi de 26,88 ton ha $^{-1}$, obtida em $\mathrm{N} 3$ (400 kg ha ${ }^{-1}$ ano $\left.^{-1}\right)$, seguida por N2 (200 kg ha ${ }^{-1}$ ano $\left.^{-1}\right)$ e N1 (testemunha), com os totais de 26,41 ton $\mathrm{ha}^{-1}$ e 18,12 ton $\mathrm{ha}^{-1}$.

A produtividade do palmito de primeira apresentou efeitos lineares com valores bem próximos em todos os tratamentos, com os totais de 0,85 ton $\mathrm{ha}^{-1}, 0,93$ ton $\mathrm{ha}^{-1}$, 1,08 ton $\mathrm{ha}^{-1}$ e 0,97 ton $\mathrm{ha}^{-1}$ para os tratamentos L1, L2, L3 e L4, respectivamente 
(Figura 33). Porém, verifica-se que a maior produtividade de palmito de primeira foi obtida para L3 (100\%ETo) e a menor, para L1 (testemunha).

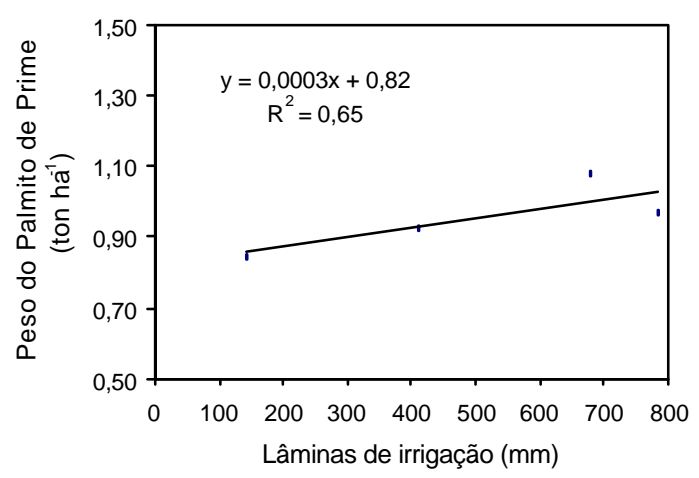

(a)

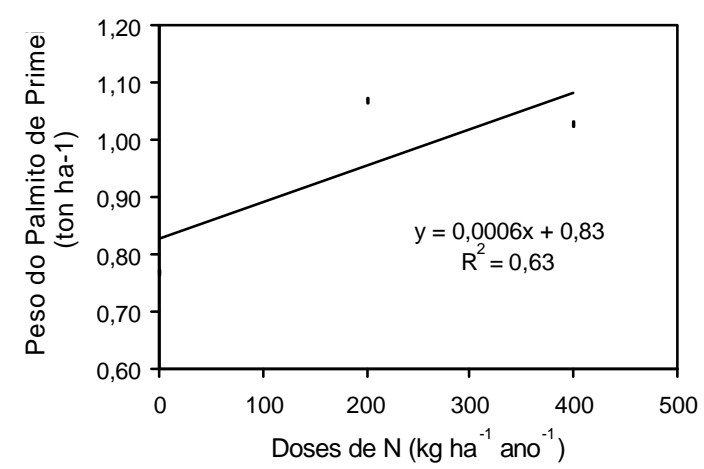

(b)

Figura 33 - Regressão linear: (a) entre as lâminas de irrigação acumuladas e o peso do palmito de primeira (ton $\mathrm{ha}^{-1}$ ); (b) entre os níveis de nitrogênio acumulados e o peso do palmito de primeira (ton $\mathrm{ha}^{-1}$ ), estimado aos 664 NDA.

Em relação ao nitrogênio, a regressão foi linear devido à magnitude de sua significância em relação à da regressão quadrática. As produtividades foram de 1,03 ton $\mathrm{ha}^{-1}, 1,07$ ton ha ${ }^{-1}$ e 0,77 ton $\mathrm{ha}^{-1}$ para os tratamentos N3, N2 e N1, respectivamente. Já, a maior produtividade obtida com a dosagem de $200 \mathrm{~kg} \mathrm{ha}^{-1} \mathrm{ano}^{-1}$ (N2).

A regressão linear entre as lâminas de irrigação e a produtividade do palmito de segunda também foi significativa. Pela Figura 34a, nota-se que para níveis crescentes de irrigação, ocorrem aumentos similarmente crescentes na produtividade. A maior produtividade foi obtida em L3 (1,64 ton $\left.\mathrm{ha}^{-1}\right)$, seguida por L4 (1,61 ton ha $\left.{ }^{-1}\right)$ e L2 (1,30 ton $\left.\mathrm{ha}^{-1}\right)$. O menor valor ocorreu em L1 $\left(1,13\right.$ ton $\left.\mathrm{ha}^{-1}\right)$, resaultando em uma queda de $31 \%$ na produtividade em relação a L3.

Para o nitrogênio, os efeitos quadráticos foram significativos, com aumentos crescentes na produtividade do palmito de segunda até certa quantidade de nitrogênio aplicada, ou seja, um ponto de máxima produtividade obtido com a dosagem de $250 \mathrm{~kg}$ $\mathrm{ha}^{-1} \mathrm{ano}^{-1}$. A maior produtividade foi de $1,7 \mathrm{ton} \mathrm{ha}^{-1}$ para os tratamentos que receberam 
N2 (200kg ha ${ }^{-1}$ ano $\left.^{-1}\right)$, seguido por N3 $\left(1,45\right.$ ton ha $\left.{ }^{-1}\right)$ e N1 $\left(1,11\right.$ ton ha $\left.{ }^{-1}\right)$, com redução de $14,71 \%$ e $34,71 \%$ no peso do palmito de segunda, quando comparados ao tratamento N2.

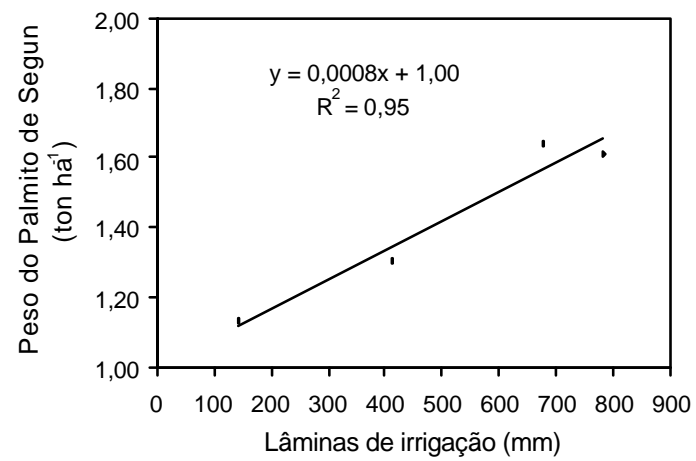

(a)

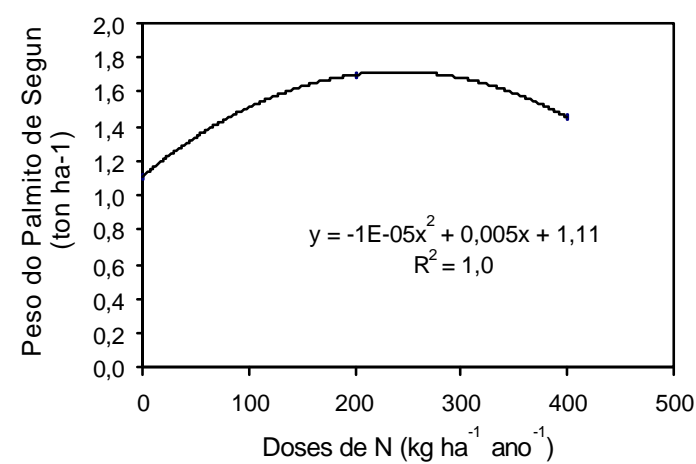

(b)

Figura 34 - Regressão linear (a) entre as lâminas de irrigação acumuladas e o peso do palmito de segunda (ton $\mathrm{ha}^{-1}$ ); regressão quadrática (b) entre os níveis de nitrogênio acumulados e o peso do palmito de segunda (ton $\mathrm{ha}^{-1}$ ), estimado aos 664 NDA.

Os tratamentos correspondentes às lâminas 3 e 4 (100\%ETo e 120\%ETo) foram os que proporcionaram as maiores produtividades, de 2,71 ton ha ${ }^{-1}$ e 2,58 ton ha ${ }^{-1}$ de palmito total, respectivamente (Figura 35a). Os níveis de irrigação L1 e L2 foram os que proporcionaram as menores produtividades totais $\left(2,23\right.$ e 1,98 ton $\left.h^{-1}\right)$, com redução de $27 \%$ e $18 \%$ na produção total de palmito em relação aos tratamentos L3 e L4. Alves Júnior et. al (2000) obtiveram uma produtividade inicial de $2,5 \mathrm{~kg} \mathrm{ha}^{-1}$, para o tratamento que recebeu lâmina referente a $100 \%$ Eto e o corte foi realizado em pupunheiras com 29 meses de campo. Estes valores são superiores à produtividade brasileira, que tem variado de 1,5 ton $\mathrm{ha}^{-1} \mathrm{ano}^{-1}$ a 2,4 ton $\mathrm{ha}^{-1}$ ano $^{-1}$, em função das variáveis como clima, irrigação, adubação, espaçamento e número de perfilhos mantidos por hectare (Bonaccini 1997); Bovi et al., 1998).

Em relação ao nitrogênio (Figura 35b), da mesma forma que para peso do palmito de segunda, os efeitos da regressão quadrática foram significativos e o maior 


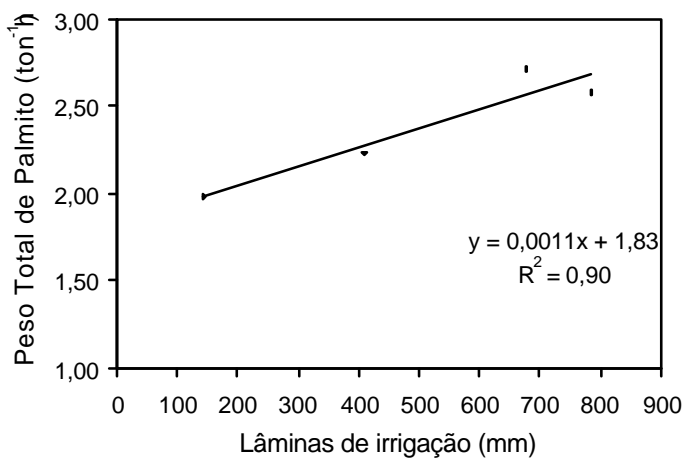

(a)

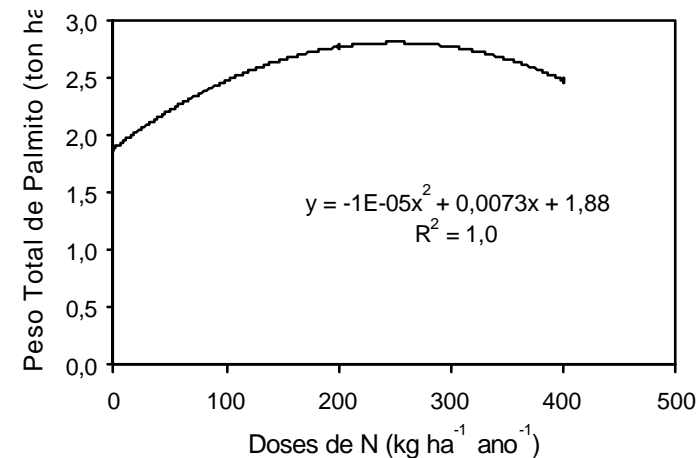

(b)

Figura 35 - Regressão linear: (a) entre as lâminas de irrigação acumuladas e o peso total do palmito (ton $\mathrm{ha}^{-1}$ ); (b) entre os níveis de nitrogênio acumulados e o peso total do palmito (ton $\mathrm{ha}^{-1}$ ), estimado aos 664 NDA.

peso total de palmito foi obtido para o tratamento $\mathrm{N} 2\left(2,77\right.$ ton $\left.^{-1} \mathrm{a}^{-1}\right)$ e o menor para N1 (1,88 ton $\left.\mathrm{ha}^{-1}\right)$. O ponto de máxima produtividade ocorreu com a dosagem de $265 \mathrm{~kg}$ de $\mathrm{N}$ ha ${ }^{-1}$

Observa-se pela Figura 35a que as maiores produtividades totais foram obtidas para L3 e L4 e as menores, para os tratamentos com maiores déficits hídricos (L1 e L2) e ausência de adubação nitrogenada (N1). Assim, é possível afirmar que o uso da irrigação foi essencial para que se obtivesse uma produtividade dentro dos padrões já alcançados para o Estado de São Paulo. Também, fica evidente a importância da adubação nitrogenada no crescimento e produtividade da cultura. Essas constatações estão de acordo com Bovi (1999) que coloca como a produção, além de outros fatores, pode ser muito influenciada pela adubação.

Para diâmetro médio do palmito (Tabela 35), não houve efeitos lineares e nem quadráticos, entre as lâminas de irrigação aplicada. Para nitrogênio a regressão foi tanto linear (Figura 36), com coeficiente de variação de 0,70\% (Figura 36), quanto quadrática. Cabe ressaltar, que a regressão linear foi muito mais significativa. Em relação aos 


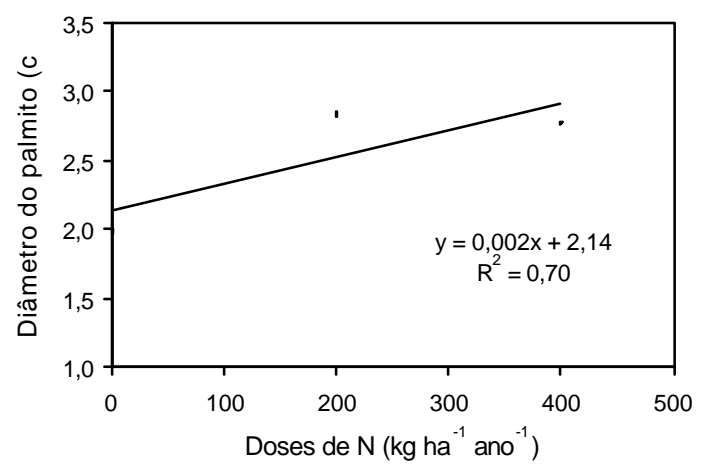

Figura 36 - Regressão linear entre os níveis de nitrogênio aplicados e o diâmetro do palmito (cm) aos 664 NDA.

demais parâmetros estudados este foi o único em que os maiores diâmetros médios foram obtidos para o tratamento L4 $(2,91 \mathrm{~cm})$, seguido por L3 $(2,71 \mathrm{~cm}), \mathrm{L} 2(2,23 \mathrm{~cm})$ e L1 $(1,98 \mathrm{~cm})$.

\subsection{Estado nutricional das plantas}

\subsubsection{Análise foliar}

Como a maioria dos processos fisiológicos são realizados nas folhas, elas refletem bem o estado nutricional das plantas. Por isso foi feita novamente, em 11/06/2001 uma análise foliar para verificar as concentrações dos nutrientes presentes nas folhas após a aplicação dos tratamentos.

Pelos resultados da análise foliar (Tabela 3) realizada logo no início do experimento, verifica-se que as folhas apresentavam de uma forma geral, concentrações inferiores as consideradas adequadas para a cultura da pupunheira, entre elas estão o $\mathrm{N}\left(35 \mathrm{~g} \mathrm{~kg}^{-1}\right), \mathrm{Ca}$ (4 $\left.\mathrm{g} \mathrm{kg}^{-1}\right), \mathrm{Mg}\left(3 \mathrm{~g} \mathrm{~kg}^{-1}\right), \mathrm{B}\left(30 \mathrm{mg}, \mathrm{kg}^{-1}\right)$ e $\mathrm{Mn}\left(142 \mathrm{mg}, \mathrm{kg}^{-1}\right)$, principalmente, para as folhas da amostra 1 (Malavolta et al. 1997). As Tabelas 37 e 38 apresentam o resultado da análise de variância para detectar os efeitos dos tratamentos 
Tabela 37. Análise de variância para macronutrientes em análise foliar realizada aos 06/11/2001 (17º período).

\begin{tabular}{cccccccc} 
& & \multicolumn{7}{c}{ Quadrado Médio } \\
\hline Causas de Variação & GL & $\mathrm{N}$ & $\mathrm{P}$ & $\mathrm{K}$ & $\mathrm{Ca}$ & $\mathrm{Mg}$ & $\mathrm{S}$ \\
\hline Lâmina & 3 & 45,801 & 0,114 & 0,880 & 1,474 & 0,067 & 0,245 \\
Nitrogênio & 2 & 98,270 & 0,911 & 2,515 & 0,365 & 0,458 & $2,666^{*}$ \\
L x N & 6 & 18,810 & 0,280 & 4,425 & 0,835 & 0,063 & 0,2667 \\
\hline Tratamento & 11 & 37,236 & 0,505 & 2,973 & 0,849 & 0,129 & 0,873 \\
Bloco & 1 & 0,0150 & 2,220 & 1,450 & 0,034 & 0,060 & 2,802 \\
Resíduo & 12 & 55,295 & 0,253 & 2,695 & 1,365 & 0,180 & 0,603 \\
Média $\left(\right.$ g gk $\left.^{-1}\right)$ & & 33,90 & 2,87 & 11,95 & 4,46 & 1,94 & 3,4 \\
CV $(\%)$ & & 21,92 & 17,53 & 13,74 & 26,19 & 21,85 & 22,83 \\
\hline
\end{tabular}

*significativo ao nível de $5 \%$ pelo teste $\mathrm{F}$

sobre a quantidade de macro e micronutrientes presentes na folha da pupunheira depois de realizadas as adubações.

$\mathrm{Na}$ análise de macronutrientes (Tabela 37) verifica-se que dos tratamentos aplicados, somente as doses de nitrogênio tiveram uma influência significativa $(\mathrm{P}<0,05)$, e mesmo assim, apenas nos teores de enxofre. Não houve diferenças estatísticas entre as lâminas de irrigação, assim como, para a interação L x N. Comparando-se as médias obtidas nesta análise, com a amostra 2 da análise anterior (Tabela 3), verifica-se que houve aumentos significativos nos níveis de $\mathrm{N}$ e $\mathrm{S}$, em menor proporção o $\mathrm{Ca}$, e $\mathrm{P}$, e diminuição nos teores de $\mathrm{K}$, e $\mathrm{Mg}$. No entanto, mesmo com essa redução o K (11,95 g $\left.\mathrm{kg}^{-1}\right)$ continua com nível superior ao considerado adequado à cultura $\left(11,0 \mathrm{~g} \mathrm{~kg}^{-1}\right)$. Por sua vez, o Mg teve seus teores reduzidos de 2,3 para $1,9 \mathrm{~g} \mathrm{~kg}^{-1}$, isto pode ter ocorrido como consequiência da adubação potássica com nitrato de potássio utilizado na fertirrigação, pois sabe-se que altas concentrações de $\mathrm{K}$ no meio, podem inibir competitivamente a absorção do Mg (Malavolta et al, 1997).

Após esta análise, foi feita análise de regressão entre as concentrações de enxofre na folha e as doses de nitrogênio. Os resultados obtidos são apresentados na Figura 37, onde se verifica que os maiores teores de enxofre $\left(3,88 \mathrm{~g} \mathrm{~kg}^{-1}\right)$ foram encontrados nas folhas das plantas que não receberam adubação nitrogenada (N1 = testemunha) e que com o aumento nas doses de nitrogênio ocorre certa diminuição na concentração de 
enxofre na folha. Quando há deficiência de S, entre outros fatores, podem ocorrer acúmulos de nitratos e aminoácidos no tecido, principalmente nas folhas (Malavolta et al., 1997).

Os níveis de enxofre, mesmo para N3 $\left(2,75 \mathrm{~g} \mathrm{~kg}^{-1}\right)$ estão acima do considerado adequado para a cultura $\left(2,0 \mathrm{~g} \mathrm{~kg}^{-1}\right)$. $\mathrm{O}$ enxofre é um elemento muito importante por ser parte estrutural da molécula de aminoácidos, proteínas (todas), vitaminas, coenzimas e ésteres com polissacarídeos, participando de processos como a fotossíntese, respiração, síntese de gorduras e proteínas. Quando há deficiência de $S$, entre outros fatores, podem ocorrer acúmulos de nitratos e aminoácidos no tecido, principalmente nas folhas (Malavolta et al., 1997).

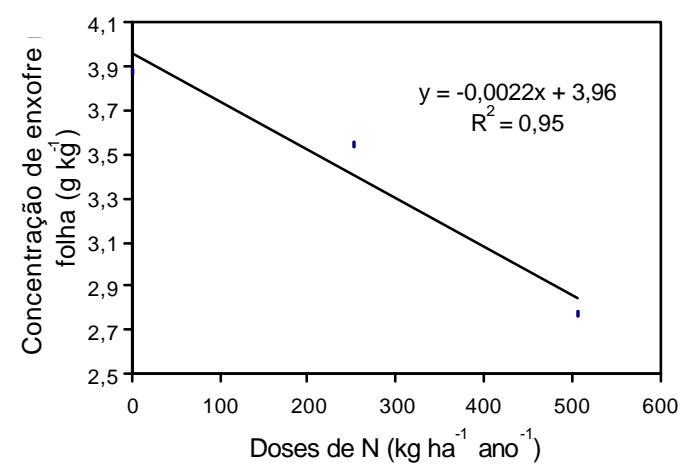

Figura 37 - Regressão linear entre e a concentração de enxofre nas folhas e as doses de nitrogênio.

Em relação aos micronutrientes, não houve diferenças estatísiticas $(\mathrm{P}<0,01$ e 0,05) entre os tratamentos aplicados, assim como, para a interação L x N (Tabela 38). Os micronutrientes $\mathrm{Cu}, \mathrm{Mn}$ e $\mathrm{Zn}$, tiveram seus níveis médios bastante elevados em relação à análise foliar realizada antes da aplicação dos tratamentos, e redução acentuada nos teores de Fe, que pode ter ocorrido, pois o manganês inibe a absorção do Fe (Malavolta et al., 1997). Os níveis determinados, com exceção do B, apresentam valores superiores aos considerados ideais para a cultura da pupunha, como o $\mathrm{Cu}\left(9,0 \mathrm{mg} \mathrm{kg}^{-1}\right), \mathrm{Fe}(126 \mathrm{mg}$ $\left.\mathrm{kg}^{-1}\right)$ e $\mathrm{Zn}\left(23 \mathrm{mg} \mathrm{kg}^{-1}\right)$. 
Tabela 38. Análise de variância para micronutrientes em análise foliar realizada aos 06/11/2001(17ºperíodo).

\begin{tabular}{cccccccc} 
& & \multicolumn{7}{c}{ Quadrado Médio } \\
\cline { 2 - 8 } $\begin{array}{c}\text { Causas de } \\
\text { Variação }\end{array}$ & \multirow{2}{*}{$\mathrm{GL}$} & $\mathrm{Fe}$ & $\mathrm{Mn}$ & $\mathrm{Cu}$ & $\mathrm{Zn}$ & $\mathrm{Na}$ & $\mathrm{B}$ \\
\hline Lâmina & 3 & 310159,72 & 223870,83 & 81122,22 & 3111,11 & 2194,44 & 4336,71 \\
Nitrogênio & 2 & 3629,17 & 452029,17 & 55837,50 & 1029,17 & 2512,50 & 5478,04 \\
L x N & 6 & 80801,39 & 137645,83 & 58693,06 & 6323,17 & 7840,28 & 2396,04 \\
\hline Tratamento & 11 & 129198,60 & 217087,50 & 66538,89 & 4345,83 & 4976,39 & 4203,96 \\
Bloco & 1 & 63037,50 & 203504,17 & 91266,67 & 2816,67 & 1066,67 & 12105,04 \\
Resíduo & 12 & 286046,60 & 146904,20 & 72593,94 & 2689,39 & 5248,49 & 4480,31 \\
Média (mg kg $\left.{ }^{-1}\right)$ & & 191,96 & 88,21 & 17,50 & 35,16 & 45,25 & 28,40 \\
CV $(\%)$ & & 27,86 & 43,45 & 153,96 & 14,75 & 16,01 & 23,56 \\
\hline
\end{tabular}

\subsection{Métodos para determinação da distribuição radicular}

Como descrito no Material e Métodos, foi feito um estudo para acompanhamento do desenvolvimento radicular pela determinação de sua distribuição espacial ao longo do tempo. Ao final da última avaliação realizada, trincheira foram abertas nas plantas que vinham sendo monitoradas. Cabe mencionar que o método indireto foi espacial e temporal e o indireto apenas espacial.

\subsubsection{Método Indireto}

Em função das determinações da umidade com sonda de nêutrons, a distribuição espacial pelo método indireto foi realizada na horizontal e vertical. Para análise da distribuição temporal, foram feitas cinco determinações, nos períodos de 15/05 a 26/06/2000 (57NDA), 29/09 a 3/11/2000 (187NDA), 03/05 a 13/06/2001 (416NDA), 05/09 a 07/11/2001(560NDA) e 05/04 a 24/05/2002 (760NDA).

Os perfis de distribuição de água no solo representam a variação da umidade obtida pela curva de calibração da sonda de nêutrons, determinada na linha (Figura 38) e entrelinha de plantas (Figura 39). O perfil I evidencia uma maior variação de umidade de 


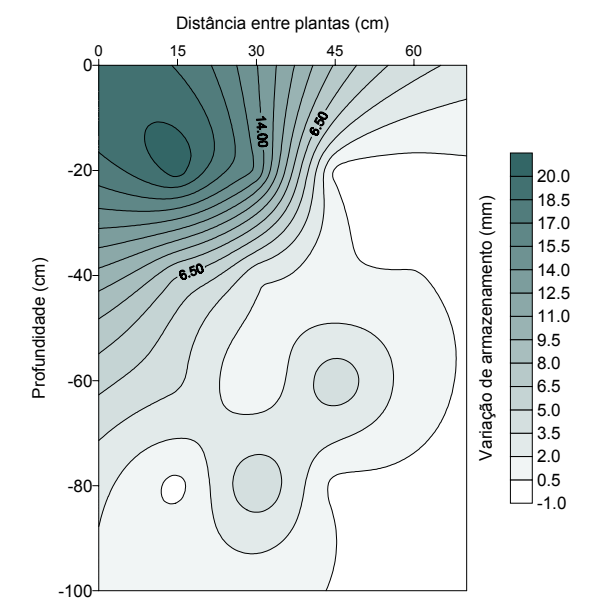

(I)

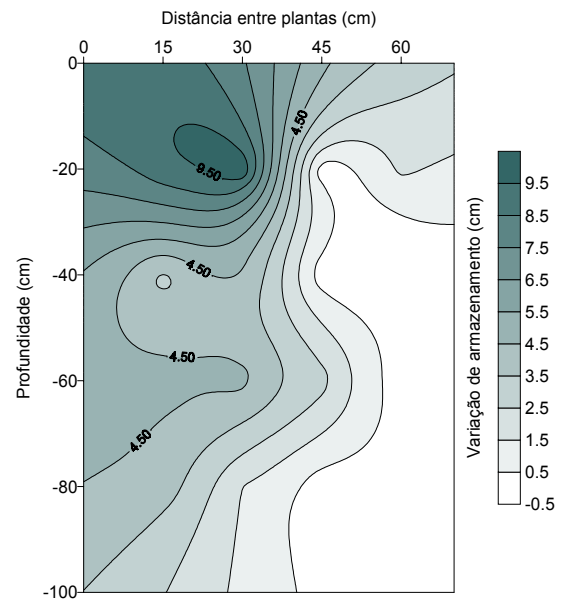

(II)

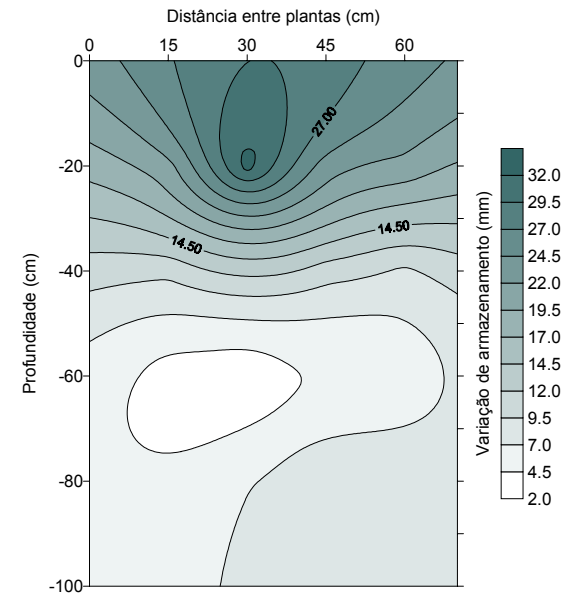

(III)
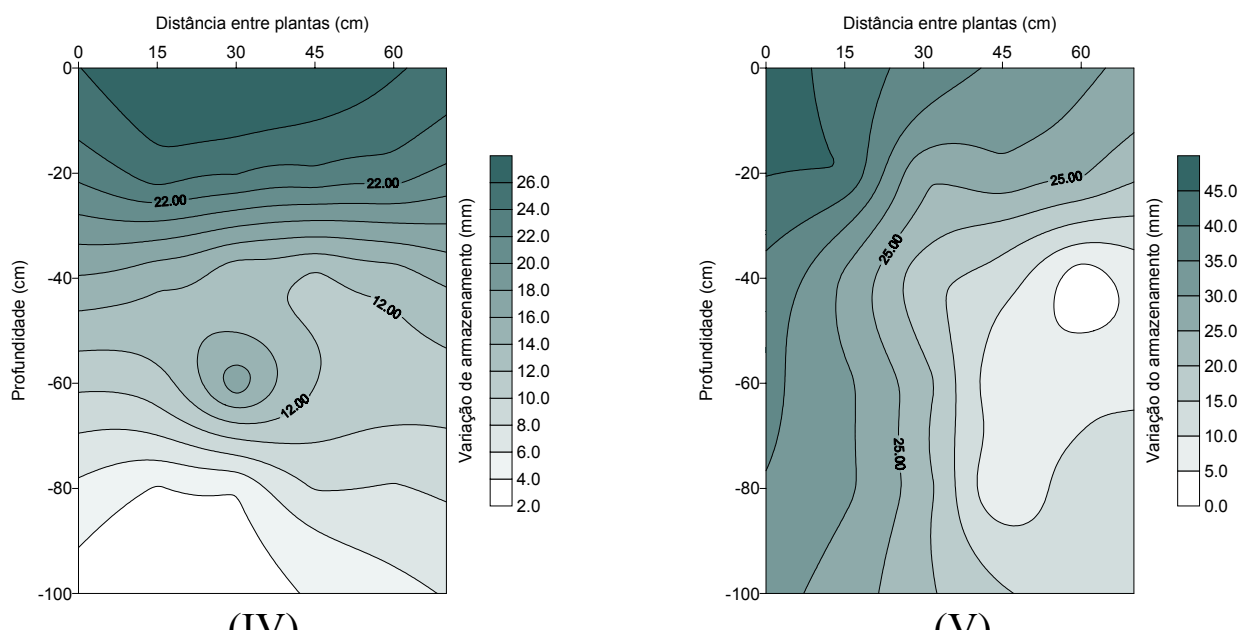

(V)

Figura 38 - Perfis de distribuição espacial de água no perfil do solo sob o nível de irrigação L2 (100\% ETo), nos períodos de15/05 a 26/06; 29/09 a 3/11/2000; 03/05 a 13/06/2001 e 05/04 a 24/05/2002, na entrelinha de plantas. 

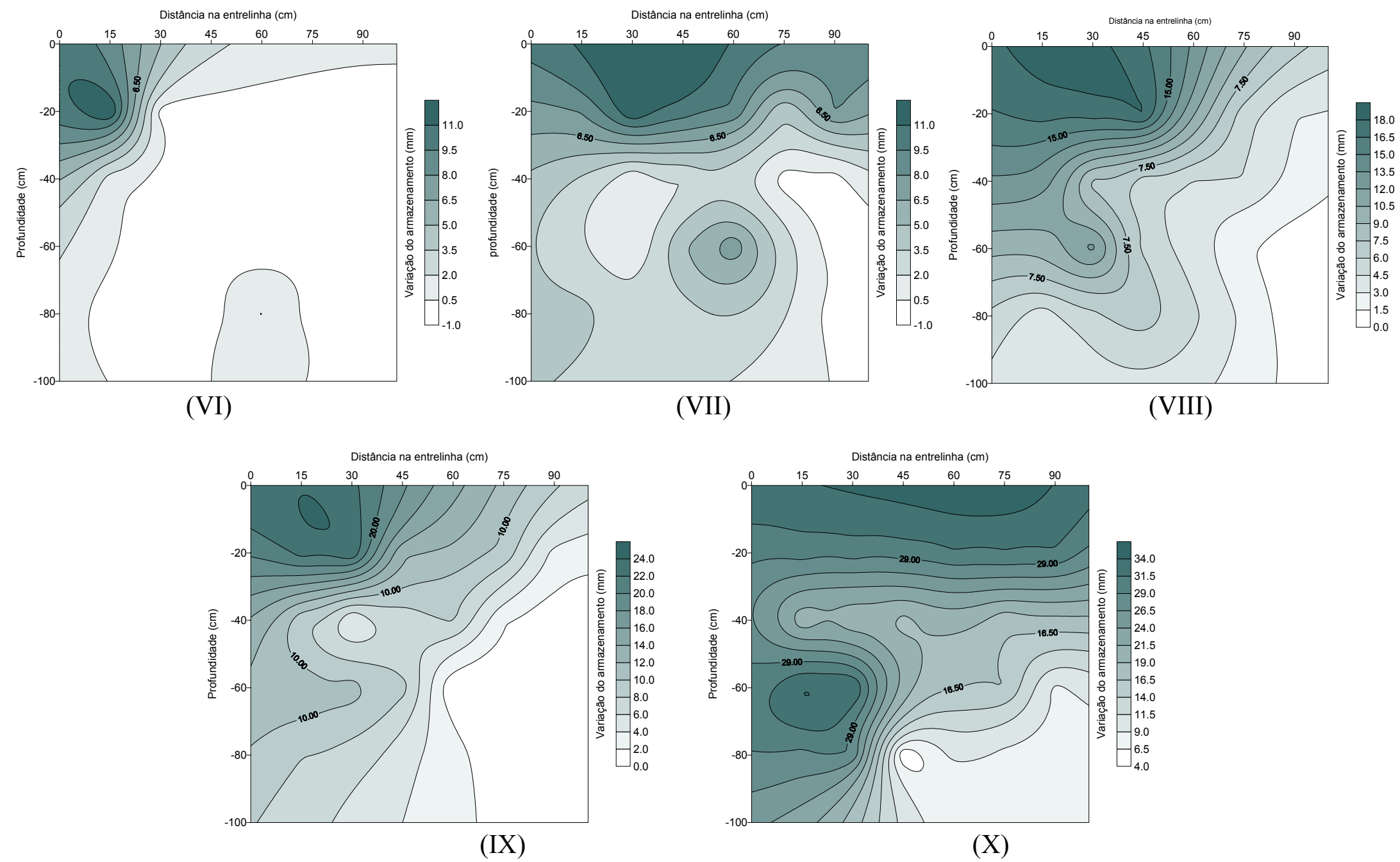

(X)

Figura 39 - Perfis de distribuição espacial de água no perfil do solo sob o nível de irrigação L2 (100\% ETo), nos períodos de 15/05 a 26/06; 29/09 a 3/11/2000; 03/05 a 13/06/2001 e 05/04 a 24/05/2002, na entrelinha de plantas. 
$16 \mathrm{~mm}$ a $20 \mathrm{~mm}$, cuja maior concentração de água se encontra a uma distância de $0,30 \mathrm{~m}$ a partir do tronco da planta (na linha) e a uma profundidade de 0,30m, aproximadamente. No perfil II, observa-se que esta variação se estendeu um pouco mais em distância. No perfil III, em profundidade, apresentou uma maior concentração até 0,25 m e a variação de armazenamento se manteve em uma faixa contínua que se estendeu até $0,60 \mathrm{~m}$ de distância. No IV a distribuição do sistema radicular também se manteve $0,60 \mathrm{~m}$ em distância e $0,35 \mathrm{~m}$ em profundidade. Ainda, esse perfil teve uma outra área com uma certa concentração dos $0,55 \mathrm{~m}$ aos $0,60 \mathrm{~m}$. Mas, existe a possibilidade desta ser referente à outra planta localizada ao lado da daquela estudada. $\mathrm{Na}$ última avaliação realizada (perfil $\mathrm{V}$ ), verificou-se um maior crescimento do sistema radicular em profundidade, com uma distribuição chegando até $0,80 \mathrm{~m}$ aproximadamente. Entretanto, a maior variação continuou ocorrendo mais superficialmente, até $0,30 \mathrm{~m}$ (35 $\mathrm{mm}$ a $45 \mathrm{~mm})$.

Os perfis VI, VII, VIII, IX e X representam a variação de armazenamento de água na entrelinha de plantas e onde se verificou, também, uma distribuição superficial. $\mathrm{Na}$ primeira avaliação efetuada, a variação de armazenamento esteve entre $0,90 \mathrm{~m}$ de distância e 1,0 m de profundidade, sendo que a maior variação ocorreu até $0,3 \mathrm{~m}$ de distância e 0,4m de profundidade, estendendo-se até $0,60 \mathrm{~m}$ de distância no perfil VII. No perfil VIII, uma maior variação se concentrou até os $0,60 \mathrm{~m}$ de distância e $0,65 \mathrm{~m}$ de profundidade. Na última avaliação realizada (perfil X), observou-se uma maior variação de umidade $(24 \mathrm{~mm}$ a $34 \mathrm{~mm}$ ) muito superficial até $0,25 \mathrm{~m}$ de profundidade e $0,90 \mathrm{~m}$ de distância. Ainda, ocorreu uma outra grande grande variação de umidade aos 0,45 m a 0,8 $\mathrm{m}$ de profundidade. Por todos esses perfis, é possível verificar a distribuição do sistema radicular em função da variação de armazenamento do solo, ao longo de todo o período observado. Desta forma, verifica-se que ocorreu uma maior variação na linha (1mm a 45 $\mathrm{mm})$ do que na entrelinha $(1 \mathrm{~mm}$ a $34 \mathrm{~mm})$ de plantas. $\mathrm{Na}$ linha de plantas, sua distribuição se manteve até $0,60 \mathrm{~m}$ de distância chegando até $1,0 \mathrm{~m}$ de profundidade, com maior concentração na camada superficial do solo, indicando uma profundidade efetiva de $0,30 \mathrm{~m}$ de profundidade. Já, na entrelinha de plantas, o sistema radicular localizou-se até 0,90 m de distância e 1,0 m de profundidade. Morales \& Vargas (1990), 
apontam o sistema radicular como superficial e expandido, uma vez que a maior concentração das raízes da planta estudada se encontrava num raio e profundidade de 0,4 m a partir do centro da planta. Bassoi et al. (1998) analisaram a distribuição da massa radicular da pupunheira irrigada por sulcos e encontraram uma maior concentração de raízes até a profundidade de $0,2 \mathrm{~m}$. nesse caso, a presença de lençol freático a $0,8 \mathrm{~m}$ de profundidade pode ter contribuído para essa distribuição bastante superficial $(0,0 \mathrm{~m}$ 0,2m). Mesmo todos concordando em definir o sistema radicular como superficial, esses resultados variáveis podem ter ocorrido graças diferenças no solo, manejo das plantas, metodologia de estudo e idade da planta.

\subsubsection{Método Direto}

Os resultados obtidos com a determinação da distribuição de raízes pelo emprego do método de abertura de trincheiras e utilização de imagens digitais são apresentados nas tabelas abaixo. As Tabelas 39 e 40 representam a distribuição espacial da área de raiz $\left(\mathrm{cm}^{2} / 400 \mathrm{~cm}^{2}\right.$ de solo) determinada em profundidade para o tratamento L2N1 (100\% ETo e $400 \mathrm{~kg} \mathrm{ha}^{-1} \mathrm{ano}^{-1}$ ), correspondendo ao valor médio de duas plantas estudadas.

Pela Tabela 39, constata-se que a área total obtida até a profundidade de 0,2 m foi de $144,71 \mathrm{~cm} 2$, correspondendo a uma percentagem de 53,22\% do total de raízes presentes até a profundidade de 1,0 m. Dos 0,2 $\mathrm{m}$ - 0,4 $\mathrm{m}$, a área de raízes diminui bastante e tendeu a diminuir cada vez mais, a medida em que aumentava a profundidade. Dos $0,8 \mathrm{~m}$ a $1,0 \mathrm{~m}$ foram encontrados $12,81 \mathrm{~cm}^{2}$ de raiz, com uma percentagem de apenas $4,71 \%$. Comportamento semelhante ocorreu com o comprimento. Grande parte das raízes estavam localizadas nos primeiros $0,2 \mathrm{~m}$ de profundidade (53,9\% - Tabela 40).

Em relação à distância lateral da planta, foram detectadas raízes até a distância de 0,6 m do tronco da planta, com aumento na quantidade de área e comprimento de raiz 
Tabela 39. Distribuição da área de raiz da pupunheira, em profundidade, para a lâmina de irrigação aplicada L2.

\begin{tabular}{cccccc}
\hline Profundidade $(\mathrm{m})$ & $0,0-0,2$ & $0,2-0,4$ & $0,4-0,6$ & $0,6-0,8$ & $0,8-1,0$ \\
\hline \multicolumn{7}{c}{ Área } \\
\hline$\left(\mathrm{cm}^{2} / 400 \mathrm{~cm}^{2}\right.$ solo) & 144,71 & 59,92 & 29,38 & 25,1 & 12,81 \\
Percentagem (\%) & 53,22 & 22,04 & 10,8 & 9,23 & 4,71 \\
$\%$ acumulada & 53,22 & 75,25 & 86,06 & 95,29 & 100 \\
\hline
\end{tabular}

Tabela 40. Distribuição do comprimento de raiz da pupunheira, em profundidade, para a lâmina de irrigação aplicada L2.

\begin{tabular}{cccccc}
\hline Profundidade $(\mathrm{m})$ & $0,0-0,2$ & $0,2-0,4$ & $0,4-0,6$ & $0,6-0,8$ & $0,8-1,0$ \\
\hline \multicolumn{7}{c}{ Comprimento } \\
\hline$\left(\mathrm{cm} / 400 \mathrm{~cm}^{2}\right.$ solo) & 853,38 & 347,02 & 156,55 & 149,17 & 77,00 \\
Percentagem $(\%)$ & 53,9 & 21,92 & 9,89 & 9,42 & 4,86 \\
$\%$ acumulada & 53,9 & 75,82 & 85,71 & 95,14 & 100 \\
\hline
\end{tabular}

com o aumento da distância lateral (Tabelas 41 e 42). Maior percentagem de área $(42,25 \%)$ e de comprimento $(39,69 \%)$ de raiz foi observada dos $0,4 \mathrm{~m}-0,6 \mathrm{~m}$ de distância, como levantado pela determinação indireta e ilustrado na Figura 42 (Perfil III e IV). Este comportamento pode ser justificado em razão da proximidade do sistema radicular da outra planta, localizada à 1,0 m de distância da planta estudada.

Tabela 41. Distribuição da área de raiz da pupunheira, em função da distância lateral da planta, para a lâmina de irrigação aplicada L2.

\begin{tabular}{cccc}
\hline Distância lateral $(\mathrm{m})$ & $0,0-0,2$ & $0,2-0,4$ & $0,4-0,6$ \\
\hline & Área & \\
\hline$\left(\mathrm{cm}^{2} / 400 \mathrm{~cm}^{2}\right.$ solo $)$ & 23,47 & 35,58 & 43,2 \\
Percentagem $(\%)$ & 22,95 & 34,8 & 42,25 \\
$\%$ acumulada & 22,95 & 57,75 & 100 \\
\hline
\end{tabular}


Tabela 42. Distribuição do comprimento de raiz da pupunheira, em função da distância lateral da planta, para a lâmina de irrigação aplicada.

\begin{tabular}{cccc}
\hline Distância lateral $(\mathrm{m})$ & $0,0-0,2$ & $0,2-0,4$ & $0,4-0,6$ \\
\hline \multicolumn{4}{c}{ Comprimento } \\
\hline$\left(\mathrm{cm}^{2} / 400 \mathrm{~cm}^{2}\right.$ solo) & 139,27 & 218,39 & 253,37 \\
Percentagem $(\%)$ & 23,48 & 36,83 & 39,69 \\
$\%$ acumulada & 23,48 & 60,31 & 100 \\
\hline
\end{tabular}

\subsubsection{Comparação entre os métodos direto e indireto}

Comparando-se os resultados obtidos pelo método direto com os determinados na última avaliação pelo método indireto, verifica-se comportamento semelhante nos dois métodos, com uma distribuição do sistema radicular bastante superficial. No método direto, grande parte das raízes encontra-se até a camada de 0,2 $\mathrm{m}-0,4 \mathrm{~m}$, contudo, foram encontradas raízes à profundidade de $1,0 \mathrm{~m}$. Para o método indireto, maior efetividade radicular ocorreu até a profundidade de $0,35 \mathrm{~m}$, encontrando-se raízes até a profundidade de $0,80 \mathrm{~m}$, afinal, esta foi a última profundidade estudada. Lateralmente, as raízes alcançaram a distância de 0,6 m para os dois métodos.

Os métodos tradicionais para análise da distribuição do sistema radicular no perfil do solo são muito trabalhosos e demorados, envolvendo contagens manuais do número de raízes presentes em um perfil de solo ou em amostras retiradas com trados ou anéis (Bohm, 1979).

O método direto empregado é trabalhoso, pois envolve, além da abertura das trincheiras, a lavagem do perfil do solo, para que se tenha uma exposição completa das raízes, pintura de todas as raízes com pincéis finos e o corte das raízes na direção horizontal para fora do perfil do solo. Caso todo esse trabalho de campo não seja muito minucioso, principalmente em relação às raízes de menor diâmetro, os resultados obtidos poderão ser discrepantes. Especificamente, no caso de plantas como a pupunheira, presume-se que existam grandes proporções de raízes secundárias e terciárias em relação 
às de maior diâmetro (Tomlinson, 1990). Bovi et al. (1999) observaram que cerca de $63 \%$ em peso dos segmentos de raízes amostradas pertenciam às classes de menores diâmetros (terciárias e quaternárias).

Além disso, como a quantificação das raízes é feita por um histograma, que representa a freqüência das regiões claras e escuras da imagem e quem determina essas regiões é aquele que está manuseando o programa, existe a possibilidade de ocorrer alterações nos resultados, caso todas as imagens não sejam interpretadas pela mesma pessoa. No entanto, estando o perfil do solo pronto, tomando-se os devidos cuidados, a utilização do SIARCS (Sistema Integrado para Análise de Raízes e Cobertura do Solo EMBRAPA/CNPDIA) vem facilitar o processo de análise de raízes, em comparação aos métodos tradicionais utilizados, que necessitam a retirada de amostras do solo.

O método de avaliação indireta, dentre os quais encontra-se o decréscimo da água no solo com o tempo, tem a vantagem de ser não destrutivo. Mas, seu emprego deve ser evitado em períodos chuvosos, pois, de acordo com Bohm (1979), a permanência do solo em potencial mátrico elevado, sem que ocorram variações de umidade no solo, não representam bem a extração de água pelas raízes. Também, é necessário que o solo tenha características físicas bem homogêneas. Contudo, comparado ao método direto, sua maior vantagem reside no fato de ser menos trabalhoso, permitir um acompanhamento do desenvolvimento do sistema radicular ao longo do tempo com maior facilidade, afora ser um método não destrutivo. Como os dois métodos apresentaram resultados semelhantes, o método indireto, desde que respeitadas suas restrições, a nível prático, parece ser o mais indicado. 


\section{CONCLUSÕES}

Baseando-se na fundamentação teórica apresentada e nos dados experimentais, obtidos conclui-se que:

As precipitações totais anuais que ocorreram durante o período experimental foram inferiores ao recomendado para a cultura e com uma distribuição temporal irregular, o que afetaria o desenvolvimento vegetativo das plantas, caso as mesmas não fossem irrigadas.

No que tange, às variações dos potenciais mátricos obtidas para cada tratamento, em L2 (50\% ETo) ocorreram os maiores valores, indicando a condição de estresse hídrico a que as plantas foram submetidas. Enquanto que os tratamentos L3 (100\% ETo) e L4 (120\% ETo) apresentaram menores variações nas leituras de potencial mátrico, entre as irrigações, devido a uma maior lâmina de irrigação aplicada.

Houve efeito significativo dos tratamentos (irrigação e adubação) para todos os parâmetros de crescimento e produtivos estudados e em grande parte dos períodos avaliados. Já a interação lâmina $\mathrm{x}$ nitrogênio não foi significativa em nenhum período estudado.

Para algumas variáveis foram observados, efeitos de bloco nos primeiro períodos de avaliação, que podem ter ocorrido como consequiência da variabilidade genética e características da cultura. Nesse caso, seus efeitos passaram a ser minimizados, quando começaram os efeitos dos tratamentos sobre o crescimento da planta. 
Os tratamentos com déficit hídrico (L2) e sem irrigação (L1) apresentaram os menores crescimentos em todos os parâmetros avaliados. O mesmo ocorreu para N1 (testemunha).

As regressões para as lâminas de irrigação tiveram efeitos lineares significativos em todas as variáveis analisadas, com exceção do número de perfilhos. Tudo isso, vem confirmar o alto consumo da cultura e a importância da irrigação, quando cultivada em áreas com déficit hídrico.

Para o nitrogênio, com exceção dos parâmetros produtivos, todos os demais apresentaram efeitos lineares das regressões, ressaltando a importância do nitrogênio no desenvolvimento vegetativo da pupunheira.

Os tratamentos L3 (100\% ETo) e L4 (120\% ETo) foram os que proporcionaram uma maior percentagem de plantas aptas para o corte. variando de $40 \%$ a $93 \%$. Ao passo que L1(testemunha) e L2 (50\% ETo), ficaram na faixa de $8 \%$ a 58\%. As maiores produtividades, também foram obtidas em L3 (2,7 ton ha $\left.{ }^{-1}\right)$ e L4 (2,58 ton ha $\left.{ }^{-1}\right)$, enquanto que os tratamentos L1 e L2 foram responsáveis por uma redução de $18 \%$ a $27 \%$ na produção total de palmito.

Os parâmetros analisados apresentaram um crescimento mais acentuado nos períodos em que foram registrados altos valores de umidade relativa, temperatura e radiação global, podendo ser este um indicativo de que não só os tratamentos aplicados influenciaram o crescimento, mas também, a época do ano.

Todos os tratamentos (lâminas) aplicados resultaram em uma distribuição radicular (área e comprimento) bastante superficial, com 97,8\%, 92\%, 86,7\% e 94,6\% de raízes distribuídas até a profundidade de 0,40 m para L1, L2, L3 e L4, respectivamente. 
Quanto à distribuição espacial do sistema radicular, no tratamento com déficit hídrico (L2) ocorreu um maior aprofundamento do sistema radicular em comparação com L1 (sem irrigação), cujas plantas apresentaram um crescimento muito retardado, acarretando em menor área e comprimento de raiz e restringindo-se a uma distribuição mais superficial, em relação aos demais tratamentos.

Apesar de não ter ocorrido diferença estatística entre os tratamentos L3 e L4, os maiores crescimentos e produtividades foram obtidos em L3 (100\% ETo). Para nitrogênio, N2 e N3 também não diferiram estatisticamente entre si. No entanto, maiores respostas foram obtidas com $\mathrm{N} 2\left(200 \mathrm{Kg} \mathrm{ha}^{-1} \mathrm{ano}^{-1}\right)$. 


\section{REFERÊNCIAS BIBLIOGRÁFICAS}

ALVES JÚNIOR, J.; HERNANDEZ, F. B. T.; LOPES, A. S.; BERGAMASCHINE, A F. Influência de diferentes níveis de irrigação na cultura da pupunha (Bactris Gasipaes H.B.K.) para produção de resíduos, objetivando seu uso na alimentação animal. (compact disc). In: CONGRESSO BRASILEIRO DE ENGENHARIA AGRÍCOLA, 29. Fortaleza - Ceará, 4 a 7 de julho de 2000. CD-ROOM.

AMORIM NETO, M. S. VILlA NOVA, N. A Novo sistema de medidas de evaporação para o tanque classe A Pesquisa Agropecuária Brasileira. v.18, n.7, p.695-702, 1983.

AVILAN, L.; RIVAS, N.; SUCRE, R. A study of the coconut (Cocos nucifera L.) root system. Oléagineux, v. 39, n. 1, p.13-20, 1984.

BARBOSA, A. M. M. Pupunha (Bactris gasipaes) In: Encontro sobre produção de palmito; FURIA, L. R. R.(Ed). Piracicaba: CALQ, 1993. p.8 -11.

BASSOI, L. H.; ALENCAR, C. M.; FLORI, J. E. Distribuição de raízes de pupunha (Bactris Gasipaes Kunth) irrigada em latossolo vermelho amarelo. In: CONGRESSO BRASILEIRO DE ENGENHARIA AGRÍCOLA, 27. Anais Poços de Caldas: Editora SBEA/UFLA, 1998. v. 1 p. 58-59.

BENINCASA, M. M. P. Análise do crescimento de plantas: (Noções Básicas), Jaboticabal: FUNEP, 1988. 42 p. (Boletim Técnico 467a).

BOHM, W. Methods of studying root systems. Berlim: Springer-Verlag, 1979. 527p.

BONACCINI, L. A Produza palmito :a cultura da pupunha. Cuiabá : SEBRAE, 1997. 96 p. (Coleção agroindústria ; v. 12: il.). 
BONNEAU, X.; OCHS, R.; QUSAIRI, L.; LUBIS, L.N. Nutrition minérale dês cocotier hybrides sur tourbe de la pépinière à l'entrée en production. Oléagineux, v.48, p.926, 1993.

BOVI, M. L. A. Manejo agronômico da pupunheira: conhecimentos atuais e necessidades. In: Seminário de Agronegócios de Palmito de Pupunha na Amazônia, 1., Rondônia, 1999. Rondônia: EMBRAPA-CPAF, 1999. p44-56. (Documentos 41).

BOVI, M.L.A. Palmito pupunha: informações básicas para cultivo. Campinas: Instituto Agronômico, 1998. 50 p. (Boletim Técnico 173).

BOVI, M.L.A. Expansão do cultivo da pupunheira para palmito no Brasil. Horticultura Brasileira, v.15, Suplemento; p.183 - 185, 1997. (Suplemento)

BOVI, M. L. A., GODOY JÚNIOR., G., SPIERING, S. H. Resposta de crescimento da pupunheira à adubação NPK. Scientia Agricola, v. 59, n.1, p. 161-166, jan./mar.2002.

BOVI, M.L.A.; LAMBAIS, M.R.; TUCCI, M.L.S., SPIERING, S.H. Biomass accumulation and vesicular-arbuscular mycorrhizal colonization in pejibaye (Bactris gasipaes) as a function of NPK fertilization. Acta Horticulturae, v. 513, n. 3, p. 153$168,2000$.

BOVI, M. L. A.; SPIERING, S. H., BARBOSA, A. M. M. Densidade radicular de progênies de pupunheira em função de adubação de NPK. Horticultura Brasileira, v. 17, n.3, p.186-258, nov. 1999.

BOVI, M. L. A.; BASSO, L. C.; TUCCI, M. L. S. Avaliação da atividade “ in vivo” da fosfatase ácida em Bactris gasipaes cultivada em dois níveis de nitrogênio e fósforo. Revista Brasileira de Ciência do Solo, v.22, n.3, p.427 - 434, 1998.

BOVI, M.L.A.; VIEIRA, S.R.; SPIERING, S.H.; MONTEIRO, S.M.G.; GALLO, P.B. Relações entre crescimento de pupunheira e alguns parâmetros físicos do solo. (compact disc). In: CONGRESSO BRASILEIRO DE CIÊNCIA DO SOLO, 26. Rio de Janeiro, 1997. Resumos. Rio de Janeiro: Sociedade Brasileira de Ciência do Solo, 1997. p.494. 
BOVI, M. L. A.; GODOY JÚNIOR, G.; CAMARGO, S.B.; SPIERING, S.H. Caracteres indiretos na seleção de pupunheiras inermes (Bactris gasipaes H.B.K.) para palmito. In: Congresso Internacional sobre Biologia, Agronomia y Industrialización Del Pijuayo, 4., Iquitos, 1991. Anais. MORA URPÍ, J.; SZOTT, L.T.; MUTILLO, M.; PATINÕ, V.M. (Eds). San José: Univ. Costa Rica, 1993a., p.163-176.

BOVI, M. L. A.; SAES, L. A.; GODOY JÚNIOR, G. Correlações fenotípicas entre caracteres não destrutíveis de palmito em pupunheiras. Turrialba, v.42, n.3. p. 382390, 1992.

BOVI, M. L. A.; GODOY JÚNIOR, G.; SAES, L. A. Pesquisas com os gêneros Euterpe e Bactris no Instituto Agronômico de Campinas. In: Encontro Nacional de Pesquisadores em Palmito, 1., Curitiba, 1988. Anais. Curitiba: EMBRAPA-CNPF, 1988. p.1-43. (EMBRAPA-CNPF, Documentos,19)

BOVI, M. L. A.; CANTARELLA, H. Pupunha para extração de palmito. In: RAIJ, B.; CANTARELlA, H.; QUAGGIO, J. A.; FURLANI, A. M. C. Recomendações de adubação para algumas culturas do estado de São Paulo. Campinas: Instituto Agronômico, 1996. p.240-242. (Boletim técnico, 100).

CHEPOTE, R. E.; VALLE, R. R.; SANTANA, C. J. L. Resposta do dendezeiro à adubação mineral. Revista Brasileira de Ciência do Solo, v. 12 p. 257-262, 1988.

CHILD, R. Coconuts. 2 ed. London: Longman, 1974. 335p. (Tropical Agriculture Series).

CINTRA, F. L. D.; PASSOS, E. E. de M. ; LEAL, M. de L.da S. Evaluation de la distribuition du système racinaire de cultivars de cocotier Grand. Oléagineux, v. 48, n. 11, nov 1993, p.453-461.

CLEMENT, C. R. Growth and analysis of pejibaye (Bactris gasipaes Kunth, Palmae) in Hawaii. Honolulu, 1995. 221p. Thesis (Ph.D.) - University of Hawaii.

CLEMENT, C.R.; BOVI, M.L.A. Padronização de medidas de crescimento e produção em experimentos com pupunheira para palmito. Acta Amazonica, v. 30 n. 3. p. 349$362,2000$. 
CLEMENT, C. R.; CHÁVEZ, F.; MOREIRA, W. B.; GOMES, J. B. Considerações sobre a pupunha (Bactris gasipaes Kunth) como produtora de palmito, In: Encontro Nacional de Pesquisadores em Palmito, 1., Curitiba, 1988. Anais Curitiba: EMBRAPA-CNPF. p.225-247, 1988. (EMBRAPA-CNPF, Documentos, 19).

CLEMENT, C. R; MORA URPI, J.; COSTA, S. de S. Estimación del área foliar de la palma de pejjibaye (Bactris gasipares H. B. K.). Revista de Biología Tropical, v. 33 n. 2. p. 99-105, 1985.

CLEMENT, C. R.; MORA-URPÍ, J. Leaf morphology of the pejibaye palm (Bactris gasipaes H.B.K.). Revista de Biologia Tropical, v.31 n.1. p.103-112, 1983.

COSTA, A. F. S.; Influência das condições climáticas no desenvolvimento de plantas de milho (Zea mays L.), avaliadas em diferentes épocas de plantio. Viçosa, 1994, 109p. Tese (Doutorado) Universidade Federal de Viçosa.

CRESTANA, S., GUIMARÃES, M. F., JORGE, L. AC. et al. Avaliação da distribuição de raízes no solo auxiliada por processamento de imagens digitais. Revista Brasileira de Ciência do Solo, v. 18, n.3, p.365-371, 1994.

DIOTTO, A V.; RAMOS, A; FOLEGATTI, M. V. Taxa de crescimento da pupunheira (Bactris gasiapes Kunth) submetida a diferentes lâminas de irrigação e sua correlação com a variação climática anual. In: SIMPÓSIO INTERNACIONAL DE INICIAÇÃO CIENTÍFICA DA USP, 8., Piracicaba, 2000. Resumos. Piracicaba: EDUSP; v.1, p. 76, 2001 (Agropecuária).

DIOTTO, A.V.; RAMOS, A.; FOLEGATTI, M. V. Balanço hídrico da cultura da pupunheira (Bactris gasipaes Kunth) irrigada por gotejamento. In: SIMPÓSIO DE INICIAÇÃO CIENTÍFICA DA USP, 7., Piracicaba, 2000. Resumos. Piracicaba: EDUSP; v.1, p. 97, 2000.

DOOREMBOS, J.; PRUITT, J. Guildlines for predicting Crop Water Requiriments. Rome: FAO, 1975. 179p. (FAO Irrigation and Drainage Paper, 24).

FERREIRA, S. A. N.; CLEMENT, C. R.; RANZANI, S. S. C. Contribuição para o conhecimento do sistema radicular da pupunheira (Bactris gasipaes H.B.K., Palmae). II. Solo latossolo amarelo, textura argilosa. Acta Amazônica, v. 25, n.3/4, p.161170, Jul 1995. 
FERREIRA, S. A N.; CLEMENT, C. R.; RANZANI, G. Contribuição para o conhecimento do sistema radicular da pupunheira (Bactris gasipaes H.B.K.Guilielma gasipaes (H.B.K.) Bailey) I - Solo Latossolo Amarelo, textura média. Acta amazônica, v.10. p 245-249, 1980

FERREIRA, V. L. P. Caracterização físico-químico-bioquímica e organoléptica do palmito proveniente da palmeira Guilielma gasipaes Bayle (pupunha) em relação ao palmito da palmeira Euterpe edulis Mart (juçara). Piracicaba, 1982. 73p. Dissertação (Mestrado) - Escola Superior de Agricultura "Luiz de Queiróz", Universidade de São Paulo.

FNP CONSULTORIA \& COMERCIO. Agrianual 1998: Anuário de agricultura brasileira. São Paulo, 1998, p.327-332.

GERMEK, E. B.; ARRUDA, H. VAZ DE; SANTOS, R. R. DOS; et al. Comportamento da palmeira pupunha em três localidades do Estado de São Paulo. In: CONGRESSO BRASILEIRO DE FRUTICULTURA, 6. Recife, 1981. Anais. Recife, p. 11991206, 1981.

GUSMAN, L. P. Nutrición y fertilización del pejibaye. Informe Labores de diversificación Agrícola. ASBANA, n.7, p.41-46, 1985.

HARTLEY, C. W. S. The oil palm (Elaeis guineensis Jacq.) 2.ed. London: Longman, 1977. 806p. (Tropical Agriculture Series).

KELLER, J.; KARMELI, D. Trickle irrigation design. London: Rain Bird Sprinkler, 1975. 133p.

LAMADE, E. Méthode rapide de mesure de l'indice foliare du palmier à huile. Plantations, Recherche, Développment, v.4, p. 385-391, 1997

LIYANAJE,L. V. K.; MATHES, D. T. Effect of irrigation on establishment and early growth of coconut (Var. CRIC 60) in the dry zone of Sri Lanka. Cocos, v.7 n.1 p. 1$13,1989$.

LOPES, A. S.; HERNANDEZ, F. B. T.; ALVES JÚNIOR, J.; VALÉRIO FILHO, W. V. Manejo da irrigação na cultura da pupunha (Bactris Gasipaes H.B.K) no Noroeste paulista. (compact disc) In: CONGRESSO BRASILEIRO DE ENGENHARIA AGRÍCOLA, 29. Fortaleza, 2000. Fottaleza: Editora SBEA , 2000. CD-ROOM 
MAGAlHÃES, A. C. N. Análise quantitativa do crescimento. In: Fisiologia vegetal. São Paulo: EPU/EDUSP, 1979. v.1, p. 331-350.

MALAVOLTA, E.; VITTI, G.C.; OLIVEIRA, S.A. de Avaliação do estado nutricional das plantas: princípios e aplicações. 2.ed. Piracicaba: Potafos, 1997. $319 \mathrm{p}$.

MARTEL, J. H. I.; CLEMENT, C. R. Comparação preliminar da área foliar de três acessos de pupunha (Bactris gasipaes H. B. K., Palmae) oriundos de três populações distintas da Amazonia Ocidental. Acta Amazônica v. 16/17 p.13-18, 1986-87.

MATHEW, J.; PILLAI, G.R.; SANTHAKUMARI,G. ; et al. Influence of supplemental irrigation on the productivity and water use of adult coconut palms. Journal of Plantation Crops, v. 21 n. 2, p. 81-87, 1993.

MILLER, J. B. A formula for average foliage density. Australian Journal of Botany, v.15, p.141-144, 1967.

MORA URPI, J. El pejibaye (Bactris gasipaes H.B.K.): origen, biologia y manejo agronómico. In: MORA URPI, J. Palmeiras Poco Utilizadas De América Tropical. Turrialba: FAO/CATIE, 1984. p. 118-160.

MORA-URPÍ, J.; WEBER, J.C.; CLEMENT, C.R. Peach palm. Bactris gasipaes Kunth. Promoting the conservation and use of underutilized and neglected crops. 20. Rome, 1997 Institute of Plant Genetics and Crop Plant Research, Gaterleben and International Plant Genetic Resources Institute, 1997. 83 p.

MORALES, A.L.; VARGAS, H.S. Observaciones sobre la distribuicion radical del Pejibaye (Bactris gasipaes HBK) para palmito en un Andosol. Revista de la Corporación Bananera Nacional, v.14, n.34, p.9-15, 1990.

NELLIAT, E. V. Effect of frequency of irrigation on newly planted young coconut palms in sandy soil. Indian Journal of Agricultural Science, v.38, n.4, p.737-746, Jan. 1968.

OLIVEIRA, A P. de; ALVES, A U.; CANDEIA, B. L.; et al. Desenvolvimento da pupunheira cultivada com fertilizante orgânico e mineral. Horticultura Brasileira, v. 19. CD-ROM, 2001.

OMETTO, J. C. Bioclimatologia vegetal. São Paulo: Agronômica Ceres, 1981. 440p. 
PARTHASARATHY, M. Drip irrigation of coconuts. Plasticulture, n.64, p.45-49; 1984.

PEARSON, R. W. Significance of rooting pattern to crop production and some problems of root research. In: CARSON, E. W. The plant root and its environment. Charlottesville: Univ. Press Virginia. ,974. p. 247-267.

POMIER, M.; BONNEAU X. Développement du systéme racinaire du cocotier en fonction du milieu em Cote-d'ivoire. Oléagineux, v. 42, n. 11, 1997, p.409-421.

RAMOS, A.; BOVI, M.L.A.; FOLEGATTI, M.V. Desenvolvimento vegetativo da pupunheira irrigada por gotejamento em função de diferentes níveis de depleção de água no solo. Horticultura Brasileira, v.20, n.1, p.28-33, mar 2002.

RAMOS, A.; FOLEGATTI, M. V.; BOVI, M. L. A. ; DIOTTO, A. V. Consumo de água da palmeira pupunha (Bactris gasipaes Kunth) pela utilização de lisímetro de drenagem. In: CONGRESSO NACIONAL DE IRRIGAÇÃO E DRENAGEM, 11., Fortaleza, 2001. Anais. Fortaleza: SBEA/FUNARB, 2001. p.53-58.

RODRIGUES, M. R. L.; MALAVOLTA, E.; CHAILLARD, H. La fumure du palmier à huile en amazonie centrale brésilienne. Plantations, Recherche, Développment, v.4, p. 392-400, 1997

SANTOS, C. A. S. Distribuição espacial e absorção de água pelo sistema radicular da cultura da manga (Mangifera indica L.) irrigada por microaspersão. Piracicaba, 1997, 51 p. Dissertação (Mestrado) - Escola Superior de Agricultura “Luiz de Queiroz", Universidade de São Paulo.

SALISBURY, F.B.; ROSS, C.W. Plant physiology. 4 ed. Belmont: Wadsworth, 1991. $682 \mathrm{p}$.

SECRETARIA, M. I.; MARAVILLA, J. N. Response of hybrid coconut palms to application of manures and fertilizers from field-planting to full-bearing stage. Plantations, Recherche, Développement, v.4, p.126-138, 1997. 
SENTELHAS, P. C.; COELHO FILHO, M. A.; VILlA NOVA, N. A.; PEREIRA, L. R.; FOLEGATTI, M.V. Coeficiente do tanque classe A (Kp) para a estimativa da evapotranspiração de referência. In: CONGRESSO BRASILEIRO DE AGROMETEOROLOGIA, 11., REUNIÃO LATINO-AMERICANA DE AGROMETEOROLOGIA, Florianópolis, 1999. Programa e resumo dos Anais. Florianópolis: EPAGRI, 1999. p.223.

TAMPUBOLON, F. H.; DANIEL, C.; OCHS, R. Résponses du palmier à huile aux fumures azotées et phosphorées à Sumatra. Oléagineux, v.45, p.475-484, 1990.

TOMLINSON, P. B. The structural biology of palms. Oxford: Clarendon Press, 1990. $463 \mathrm{p}$.

VILLACHICA, L. Cultivo del Pijuayo (Bactris gasipaes Kunth) para palmito en la Amazonia. Lima: SPT/TCA, 1996. 146 p.

VIZQUEZ, N. F. S Aspectos fenológicos de pejibaye (Bactris gasipaes H.B.K.). San José, 1981. 60p. Dissertação (Mestrado) - Universidade da Costa Rica.

WHITNEY, J. D.; ELEZABY, A.; CASTLE, W. S.; et al. Soil water use, root density, and fruit yield for two citrus tree spacings. Proceedings of the. Florida State Horticultural Society. v. 103 p.50-54, 1990.

ZAMORRA, F. D; FLORES, S. Ensayo sobre niveles de fósforo en pejibaye para palmito. ASBANA, v. 6, p. 62-65, 1985. 